Portland State University

PDXScholar

1973

\title{
Selected attitudes and perceptions of adolescents at the Hood River, Oregon, attention home
}

\author{
Marilyn Czerwinski \\ Portland State University \\ Linda Olson \\ Portland State University
}

Follow this and additional works at: https://pdxscholar.library.pdx.edu/open_access_etds

Part of the Juvenile Law Commons, and the Social Work Commons

Let us know how access to this document benefits you.

\section{Recommended Citation}

Czerwinski, Marilyn and Olson, Linda, "Selected attitudes and perceptions of adolescents at the Hood River, Oregon, attention home" (1973). Dissertations and Theses. Paper 2877.

https://doi.org/10.15760/etd.2868

This Thesis is brought to you for free and open access. It has been accepted for inclusion in Dissertations and Theses by an authorized administrator of PDXScholar. Please contact us if we can make this document more accessible: pdxscholar@pdx.edu. 
SELECTED ATTITUDES AND PERCEPTIONS OF ADOLESCENTS

AT THE HOOD RIVEH, OREGON

ATTENTION HOME

\author{
try \\ MARILYN CZERWINSKI \\ LINDA OLSON
}

A report submitted in partial fulfilinent of the requirements for the degree of

MASTER OF

SOCIAL WORK

Portland State Unlversity 1973 


\section{FOREWORD}

The basis of this study was a contract between Martha N. Ozawa, Ph.D, and James E. Klahre, Chalman of the Board of Next Door, Inc., for a team of graduate students to "use various measuring devices to evaluate changes of perception and att1tudes of the juveniles in resldence."

Detalls of the study were worked out with Dr. Clinton Goff of the Salem Law Enforcement Council, reviewed by the Board of Directors of the Next Door, Inc., and the work commenced 1n April of 1972. In August, Dr. Orawa left the project, and Dr. Frank F'. M1les became the director.

The basic hypothesis of this study was that "Juveniles who had been in the Next Door, Inc. would show a positive change in their perceptions and att1tudes towards themselves and their community after a stay of two months." However, It was recognized that two months might be too brief a time span to reveal significant changes in the Juvenilest attitudes and perceptions.

The main variables chosen for this study were the youths' responses towards authority, communt ty, peer 


\section{1}

relationships, self-concept and the program of the Next Door, Inc. Data was collected on these variables by means of four separate but related measures: the Jesness Inventory, an Attitude Questionna1re, Semant1c Differential Scales and interviews held with the Juveniles by the researchers. 
TABLE OF CONTENTS

PAGE

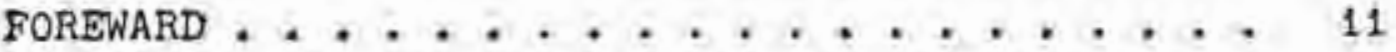

LIST OF TABLES .................

IIST OF FIGURES ............... $1 \times$

CHAPTER

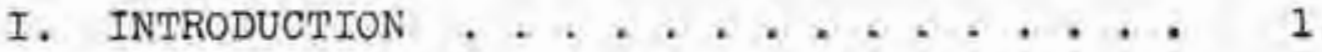

Development of Focus ......... I

Development of the Next Door, Inc. . . 6

Purpose of Study ........... 11

Value of Research .......... 12

Dvervlew of Chapters ....... 13

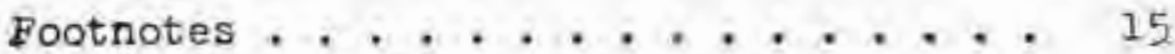

88. REVIEW OF THE LITERATURE ........ I6

Adolescence................ 16

Author1ty ............... 21

Peers and Self-Concept ....... 23

The Treatment Home ....... 26

Footnotes.............. 32

III. METHODOLOGY .............. 35

Hypotheses ............... 35 
Population Studied............ 35

Instruments of Data Collection . . . . 37

Jesness Inventory . . . . . . . 37

Attitude Questionnaire . . . . . . 40

Interview............... 42

Collection of Data........... 43

Analysis of Data........... 44

Base Data................ 44

Jesriess Inventory . . . . . . . . 45

Attltude Questlonnalre ........ 48

Semant1c Differential Scale ..... 48

IV. FINDINGS ................ 50

Base Data ............. 50 . .

Jesness Inventory ............. 60

Analysis of Individual Cases . . . . 68

Seven Male Entrance Scores . . . . 72

Att1tude Questionnalre ........ 70

The Semantic Differential . , , . , . 84

Subjective Interview Responses . . . . . Bg

V. SUMMARY AND IMPLICATIONS . . . . . . . . 95 BIBLIOGRAPHY . . . . . . . . . . . . . . 103 APPENDIX A

ADMISSION CRITERIA FOR YOUTH HOMES IN HOOD RIVER . . . . . .... . 107 
PAGE

CONTRACT FOR NEXT DOOR, INC, . . . . . 109

PROGRESS REPORT FORMS *.+.+*,+,+, 110

APP ENDIX B

JESNESS INVENTORY . * . . . . . . . . 111

ATTITUDE QUESTIONNAIRE . . . . . + + + + 124

SEMANTIC DIFEERENTIAL SCALES . . . . . I26 


\section{LIST OF TABLES}

TABLE

PAGE

I. FLOW CHART OF JUVENILES IN THE NEXT

DOOR, INC., FROM NOVEMEER 15, 1971 -

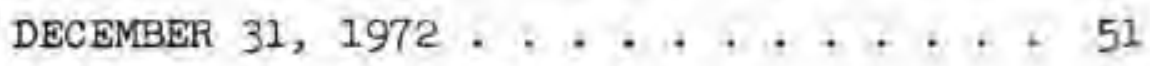

II. PLACEMENT UPON RELEASE FROM THE

NEXT DOOR, INC. ........ 55

III. REASONS FOR REFERHAL TO THE NEXT DOOR,

INC. ............... 56

IV. JUVENILES DETAINED OVERNIGHT OR LONGER

IN THE HOOD RIVER COUNTY JAIL -

NOVEMBER 15, 1971 - DECEMBER 31,

$1972 \ldots \ldots \ldots+\ldots \ldots+\ldots \ldots$

V. NUMBER OF DAYS IN THE NEXT DOOH,

INC, ............. 59

VI. TWO-TAILED TEST OF SIGNIFICANCE FOR

RELATED MEANS FOR JESNESS SCORES AT

TIMES I AND II $(N=4) \ldots . . . .6 I$

VII. T SCORES FOR TIMES I AND II ON ALL

SCALES FOR $N=4 \ldots 69$

VIII, COMPOSITE SCORES OF SEVEN MALES UPON

ENTRANCE TO THE NEXT DOOR, INC. . . . 73 
IX, TWO-TAILED TEST OF SIGNIPICANT DIFFERBNCE FOR JESNESS ENTRANCE SCORES FROM THE NEXT DOOR, INC., AND THE MIDVALIEY TREATMENT CENTER $(\mathrm{N}=7) \ldots 74$

X. TWO-TAILED TEST OF SIGNIFICANCE FOR RELATED MEANS; COMPARING FIAST AND

IAST SCORES (ASOCIAL INDEX) , ... 76

XI. SEMANTIC DIFFERENTIAL SCALE SCORES FOR THE NEXT DOOR, INC. ....., . . B5

XII. SEMANTIC DIFFERENTIAL SCALB SCORES FOR AUTHORITY ................. B6

XIIT. SEMANTIC DIFEERENTIAL SCALE SCORES FOR SELF-CONCEPT ........... 87 XTV. RAW SCORES CONVERTED INTO RANK SCORES ON SEMANTIC DIFFERENTIAL SCALE . . . . . 80 


\section{IIST OF FIGURES}

FIGURE

PAGE

1. FRIENDS ,....,...., 77

2. FAIRNESS ............. 78

3. COMIUNITY/AUTHORITY .........79 79

4. COMMUNITY CONCERN ........ 80

5. LEARNING EXPERIENCE ........ 81

6. SELF-CONCEPT ......... 82

7. HOUSEPARENTS ............ 83

8. PEER RELATIONSHIPS , ....... 84 


\section{CHAPTER I}

\section{INTRODUCTION}

The alm of this study is to report selected perceptions and attitudes of adolescents placed in the "attention home" at Hood River, Oregon, as an early ald towards 1 mproved understanding and treatment, and program assessment.

\section{Development of Focus}

In the past quarter of a century, emphasis in the mental health and correctional fields has shifted from an Increasingly impersonal and reglmented philosophy to a more meaning $f u l$, individualized approach. This is especially apparent in the correctional field in which Individualized treatment in smaller, community-based units, such as group homes and half-way houses which provide a f'amily-like atmosphere, Is seen as a desirable alternative to eustodlal care and punishment carried out in a large-scale institution. Until recently, little such individualization has been provided for li. the United States: adults have been housed with juven1les; dependent and reslected chlIdren have been 1 nstitutionallzed along with adjudieated delinquents. 
Many researchers have long turned their attention to the conditions, structure and objectlves of our ja1ls, and have found reason for much criticlsm.

The Federal Bureau of Prison ratings point out that almost no fails are rated excellent by their standards; about half are rated good, a third as falr, and $s 1 x$ to seven per cent as poor. 1 These ratings are made in terms of sultability of jalls for adults, not for chlldren. Among the major problems surveyed are 1dleness, untrained personnel, and lack of provielons for education of youth, recreation and religion. Inadequate provision 1 s made for separation of adult from Juventle offenders; often when there is separation, one or two fuvenlles are isolated completely. ${ }^{2}$

W1th the establishment of Juvenile court Iaws in 1899, the juvenile code provided for detention of children separate from that of adult offenders. The court malntalned that juvenile lawbreaking differed from that of adults in that it does not have the same Implications of moral deviation or intentional disregard of the law. The court maintalns that children under the Jurisdiction of the Juvenile Court are in need of protective care and guardianship, and that this can best be carried out in flacilities for detention and treat- 
ment which are separate from criminal adult influence and stigma of crime,

The case for the development of such fac1lities designed to provide individualized treatment for the Juvenlle has gained strength as we learn more about the causes of antf-soclal and abnormal behav1our. Konopka stresses that treatment of the Juvenile delinquent must be communty centered because self-respect and dignity grow from human relationships, both with peers and accepting adults. 3 Kvaraceus cautlons us that the level of commity understanding and acceptance correlates h1ghly with the success of programs designed for deIinquent youth. The larger part of the communlty must support the values and philosophy of the program rather than feel it is a soft-hearted or 1neffective approach to delinquency. Fallure to achleve this understanding on the community's part can result in fallure of the program. 4

An essential aspect of the effective detention faclilty is provision of an opportunity to observe the juvenile in a controlled envivonment in which there is Iove, understanding and security and in which his physloal needs will be met. Hardman notes that slnce one of the basic components of delinquency is a history of negative experiences with authority flgures, an of- 
fender can make a true adjustment only through reconclilation with authority or through a new and construct1ve relationship with an authorlty figure. ${ }^{5}$ The personnel Involved with the detalned juventle offender should represent authority as understanding, dignifled and consistent to change the fuvenile's view of authorIty as unpredictable, host1le and rejecting.

Ja1l detention seldom provides such positive experlences as described above and frequently has even more undesirable consequences. Many studies indicate that confinement of a juvenile in jall gives him a delinquent status among peers. Studt malntains that the traumatic experience of being housed with adult criminals often reinforces noninvolyement with the normal community and widens the Juventle's separation from normal group controls which the community prov1des. ${ }^{6}$ The adolescent, who st111 has his cholce of several self-concepts, fluctuates between conformlty and under-conformlty, ${ }^{7}$ The child's self-concept grows out of his perception of what others think of him. By confining the child in fail with adult criminals, soolety 1mplies that he, too, is "bad," thus lowering his self-coneept and possibly precipltating further delinquency. 
Furthermore, the Jall experlence, whlle prevent1ng the repetition of a specific act, may instill in the youthful offender a cautiousness and wariness of cormunity-sanctioned authority figures and agenc1es. The philosophy of imprisonment as punishment of ten inhlblts constmictive efforts toward conform1ty to society's norms. Kenney states that Juveniles often need detention but reminds us that the detention experience should begin the treatment process rather than push the 1ndividual further from 1 . $^{8}$ A punitive att1tude based on the premises of retaliation and removal from the communty encourages resentment and 1 nhiblts growth of motivation toward resocialization. 9 The process of resociallzation necessarily involves a desire to change as well as a gradual process of reorganlzing behavior by means of practicing new attitudes, roles and behavior. It is our belief that resoclallzation is more effectively achieved in detention homes deslgned to provide exposure to positive, successful and desirable ways of behaving than it is achleved in the tradltional fall setting. The workers and members of a detention home offer several methods of transmithing soclety's norms. Behavior can be influenced by approval or disapproval of the members of the home. The soclalization process can also be effected in a deten- 
tIon environment created to perpetuate and refnforce aoceptable norms. The norns are internalized into each member of the home as the individual becomes his own Judge of his behavior.

Development of the Next Door, Inc.

The State of oregon Corrections DIvision carried out a study of District 9, comprising Wasco, Sherman and Hood River countles, to provide direction for correctional change in that district. The Feasibility Study team held the opinion that treatment cannot be conducted within a fail setting and that it is most effective within the local community. In view of this, the study identified the critlcal problem in District 9 as the lack of a detention resource for children of Juvenile court age. ${ }^{10}$ The Law Enforcement Counc1l of oregon, in a grant proposal for the creation of such a faclity in District 9, 11sted specific problems caused by the lack of a temporacy child care faclilty:

1. Chlldren alleged to have committed acts of delinquency must either be detalned in inadequate Ja1I-11ke facilities or released to the custody of their parents. often the home situation is harmful to the child and the release of the child to his parents only perpetuates and aggravates the child's problems. 
2. Sometimes it is necessary to lodge dependent children in the Juvenile Quarters of the Hood River County Jail aue to a lack of any other temporary housing for the child.

3. Evaluation of the child's needs by the Court is of ten hampered by the lack of temporary care facilitles.

4. Ch1ldren coming before the Court with problems in the area of ungovernable behavior or situations of family conflict cannot be helped effectively because temporary care in a neutral setting is not avallable. 11

Recognizing these needs, Hood River, Oregon has developed an "attention home" called the Next Door, Incorporated.

The Next Doos, Ino.

The Next Door, Ino, a temporary chlld care facllity located in the community of Hood Rlver, has been funded by Federal, State, and Local sources under Part C, Iltle I, Public Law 90-351, (as amended by Pub11c Law 91-644). The Next Door, Inc. serves Hood River, Wasco and Sherman counties and is certifled by the Children's Services Division for a total of eight chlldren of both sexes. The technical age for placement Iles between ten and elghteen years of ager although the majorlty of Juvenlles placed in the hame have been acolescents. Placement in the group home is for both long and short tern clientele referred from 
the Juvenile courts, from Children's Services Division, or on a voluntary basis. Children admitted to the attention home must meet the admission oriterla formulated by the Hood RIver and Wasco County Juvenlle Departments. In addition each child must slgh a contract stating clearly that he w11l cooperate with the program of the attention home (see Append1x $\Lambda$ ).

The physical facility is a large, older home in Hood R1ver, Oregon which has been remodeled to accommodate both sexes. Its location provides proximity to local schools and other participating community agencles.

The Next Door, Inc. 18 administered by a Board of Directors consisting of iffeen community volunteers who assume the responsibility of managing and directing the operation of the group home. Houseparents are responsible for the actual care and superviston of the children in residence as well as for the planring and coordinating of the children's needs. Together these two teams work towards achleving the goals of the attention home. These goals have been formulated by the Board as follows:

1. Temporary Child Care: To provide temporary care for up to elght chlldren of both sexes as an alternative to placement of the child in jall or return to an unfavorable home altuation. The home 
is to be operated princlpally for the children of Hood River County, but children from Wasco ana Sherman counties iw 111 be admitted on a space ava1lable and cost of care basis.

2. Attention to the Child's Needs: To develop and prov1de various types of attention for the child not possible If the child were detalned in Jall or released to his parents or even placed in shelter homes. The houseparents, commun1ty volunteers, and professional oounsell1ng personnel w111 be Involved in providing attention to the child's various needs and problems.

1. Neutral Place for the Child to Stay: To provide a neutral setting for the child to stay for counselling and assistance following periods of fam1ly conflict. It w111 provide a cooling of' period for both the child and parents and on-going care for those children needing specific services not ava1lable w1thin thein own homes. Parenta $W 111$ be involved in the counselilng and program plannling whenever possible.

4. Place for Ch1ld to Stay Other Than Jall Pending case Planning and/or plaoement: To provide a place for the child pending case planning and/ or continuing care when not appropriate to release the child to his parents or to continue the child in detention.

5. Assist the Court in Evaluating Child's Needs: To provide evaluation information to the court prior to hearing and if contlnuing care is necessary, make available counseling to the child.

6. Minimize the Child's Adjustment Program: To provide care and service to the chlid and hls famlly while disturbing his world as Iftie as pos- 
sible; that $1 \mathrm{~s}$, the child will be allowed to continue in school and be allowed to remain in contact $w I t h$ persons and things familiar to him.

7. Obtain Volunteer Services from the Communlty: To secure the volunteer participation of at least one hundred individuals and/or organizations in the community. The particlpation is expected in the form of volunteer servlces such as preparation and remodeling of the facility, upkeep of facility, obtaining supplies, b1g brother services, contributions of money, etc.12

Through interviews with the houseparents, the research learned that in addition to these basic goals the houseparents have objectives relating to dally $11 v-$ Ing experiences. Some of the tasks include provision of structure and routine schedules for those chlldren who have never had such discipline. The houseparents hope to help these children improve their relationships with adults and with their peers through role modeling as well as through individual counselling and group meetings. Problems of honesty, sharing and getting along with others are discussed among the houseparents and children to achieve this goal. The houseparents also try to provide a model of a healthy and stable marrlage for the chlldren, many of whom have never been exposed to this. The houseparents delegate household chores and Involve the children in recreational and Broup act1vities in order to provide a more fam1ly-11ke 
atmosphere. In carrying qut their parental role the houseparents are expected to use firm and consistent discipline, hoping to 1nstill a more positive view of authority in the children.

The houseparents enter weekly progress and behavioral reports into each child's file to help evaluate the child's needs and to plan for placement upon release (see Append1X A). The houseparents meet with a planning committee conslsting of a Children's Servlces Division worker, Juventle court personnel, a clinical psycholog1st, a psychlatric social worker, and other community volunteers to discuss the child's. adjustment and future alternatives such as foster care, return to natural parents, or inst1tutionalization.

\section{Purpose of Study}

The purpose of our study is to explore the value of the Next Door, Inc, program in tems of Its effect on the children's attitudes towards and perceptions of, various components considered important to the group home's program. These components 1nclude the group home 1tself, the child's view of authority figures, his self-concept, his peer relationships, and his percept1on of the comminity's cancern for him. 
Th1s research attempts to measure att1tude change In those children who have reslded in the home for a period of at least two months. In addition, the design allows us to formulate a description of the population served by this facility. Subjective comments from the resldents of the home are used, to provide a broader vlew of the fuveniles' feelings and perceptions.

Th1s should provide some measure of the 1mpact of the attention home's program on relevant attitudes held by 1 ts cllentele, as well as a clearer description of the clientele with whom the home is dealing. The research findings should provide a base for analysis and improvement or modification of program aspects. It is hoped that such clarification in terms of the population presently dealt with will give direction to determination of program objectives and simultaneously provide a base for further research in this home, if not other fac1lities.

\section{Values of the Research}

The value of attention homes such as the Next Door, Inc, recently put into practice in many commultles, has been 1ncreasingly advocated as a viable alternative to traditional detention. The implicatione of a community based attention home are far reaching 
In that the attention home represents a shift from rellance upon impersonal and highly centrallzed agenc1es which are sald to have contributed to an unmot1vated and uncomitted philosophy pervading many communities. Some soclal sclent1sts belleve that community participation and active involvement in the solution of soclal problems, as demanded by community based group homes, result in a more effective and humanized service.

The possible significance of communtty group homes to the growth and advancement of both the mental health and correctional flelds requires further research in this area to provide direction for its most effective utilization, as well as to provide guldelines for program assessment, development and Implementation. Thus, the present research on the Next Door, Inc. was conducted in order to provide some such measure of the group home's value and effectiveness as an Innovative effort in the Oregon Correctional system.

\section{Overview of Chapters}

The remalning chapters of this book will be devoted to a review of the relevant 11 terature and to the actual implementation and indings of this research. Chapter II is divlded Into two sections, the flrst of 
wh1ch provides a broad overvlew of the adolescent personallty with which the home deals. The second section presents the research findings concerning adolescent treatment facilities in order to determine what factors contribute to an effective group home. Chapter III describes the research des1gn and methods of data analysis. Findings of the research are presented in Chapter IV. The final chapter summarizes conclusions of the study and suggests implications for the program of the Next Door, Inc. 


\section{FOOTNOTES - CHAPTER I}

1. Ruth Cavan, Juvenlle Delinquency, J. B. L1pplncott Co., Philadelphia, Pa.; 1909, p. 391.

2. Ibid., p. 39 .

3. Gisela Konopka, "Our Outcast Youth," Soc1al Work, Vol. 15, No. 4 (oot., 1970), p. 81.

4. William C. Kvaraceus, The Communtty and the Delinquent, WorId Book Co, New York, 1934, p. 161 .

5. Dale G. Hardman, "The Constructive Use of" Authority," Crime and Delinquency, Vol. VI, (July, 1960), p. 250 .

6. Elllot Studt, "An Outline for Study of Social Authority Factors in Casework," Soclal Casework, Vol. 35, (June, 1954), D. 235.

7. Ruth Cavan, op. c1t., p. 276.

8. John P, Kenney, Pollce Work with Juveniles, Charies 0. Thomas, Sprimglield, IIl., IF54; p. 104.

9. Ibid., p. 20.

10. Don C. Gibbons and Duane C. Lemley, Correctional Feasibility Study, District 9, State of oregon Corrections Division, Salem, Oregon, 1971, p. 20.

11. Application for Actlon Grant, State Law Enforcement Planning Agency, Project Title: The Next Deor, Inc., p. 2, attachment 1 .

12. Ibid., p. 2, attachrient 1. 
REVIEW OF THE LITERATURE

Adolescence is a period of transition from childhood to adulthood, during which the youth experiences eruclal physlologloal and psychologidal changes. Besides coping with the bewildering onset of glandular and bodily changes, the adolescent youth must also contend w1th psychological changes, called "tasks" of adolescence. These "developmental tasks" are deflned by Havighurst as:

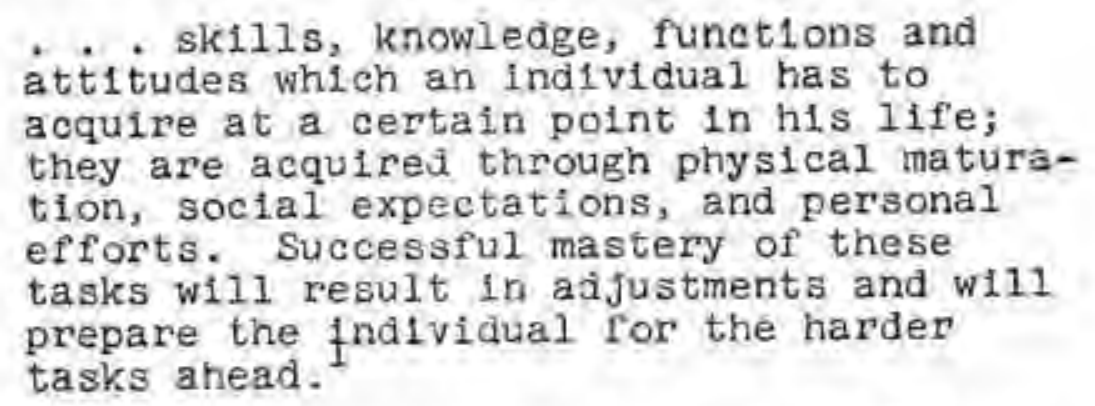

A primary task of this age is achlevement of adult status and independence. The reawaken1ng of sexual interest characteristic of adolescence requires a second task, that the youth experiment with new relat1onshlps w1th both sexes, as well as accept his own sexual identity and $1 \mathrm{ts}$ concurrent role. Other tasks Include dealing with and accepting his new body Image, 
Iearning to integrate soclety's norms and mores as his own; and flnally, establishing a sense of 1dentity.

The establishment of 1dent1ty, defined by Sorenson as "the creation of an Inner sense of sameness and continuity, a unity of personality felt by the individual and recognized by others, "2 is essential to the transition from adolescence to mature adulthood. Erickson reminds us of this diffleuIt period, when the youth is concerned about who he 1s, who he wants to be, what others feel about him, how to master powerful new drives and how to cope with authority as well as new responsiblilties. When a youth is not sure of how he sees himself or of how others see $h 1 m$, that $1 \mathrm{~s}$, when he is not sure of his ldentity, delinquent, neurotic, and even psychotic Incldents may result. 3 When such "1dentity diffusion" occurs, the youth runs away in some form--truanting, staying out all night, withdrawing from frlends or family. Erickson emphasizes that delinquent behavior is only one manifestation of diffusion. ${ }^{4}$ He cautions us agalnst using the label delinquent, warning us that the youth may perversely oblige authorities by becoming what he is labeled, Delinquency, according to Lippman, is an outlet for host11ity resulting from past neglect, refection, or deprivation of vitally needed gratifications. 5 The 
U.S. Children's Bureau publication, Inst1tutions

Serving Delinquent Chilaren, throws further 11ght on

the dilema of defining delinquency:

"Delinquency" is a legal term, a findIng by a court, generaliy as a result of the child's violation of a law. The term is not dlagnostic and is not surflclent to classlfy the child. Chance sometimes determines whether a child is labeled delinquent, dependent, or neglected. Sometimes another term might easily have been used and the child glven a different legal-soclal status . A A child may become delinquent because his life lacks some of the elements necessary to healthy, normal growth.... When these basic needs are not met, a child may become delinquent and seek his satisfactions in soclally unacceptable ways . . . . Whatever the causes of the1r $\mathrm{m} 1 \mathrm{sbe}-$ hav1or, delinquents are 11kely to be 1 mmature, hostile, insecure, or badiy frightened boys and girls. Most delinquent children belleve that the world Is essentialiy hostile, sirice this is what their experlence of rejection and deprivation has taught them. 6

Keller and Dliver note that "sharp d1lineations

between delinquent and dependent ch1ldren are more easily made by law than in practice."7 They ma1ntain that onflaren in need of care, regardless of thelr label, are more s1milar than different, Many of these children share the same deprivations in splte of their vary1ng labels. Dependent and neglected chlldren, like many dellnquent chlldren, have been "abandoned, neglected, subfected to cruelty or depray1ty or not pro- 
v1ded with the care, guldance, and protection necessary for his physical or emotional well-being, by h1s. parents or those having his custody." 8

A major factor from which many of these deprivations stem is the inadequate fam11y. Sheldon and Eleanor GIueck found that the parent-child relationsh1p in a family held more import in contributing to delinquency than the factors of slum 11 f'e, conflict of cultures, and low IQ. The chances that a youth with an adequate family life would become delinquent were only three In one hundred, whereas a youth with an Inadequate family Ilfe was given ninety-elght chances out of one hundred. 9

The Inadequate familles studied by the Gluecks were found to be more mobile, crowded, and with a lower standard of Ilving. The parents were often divoreed, separated, unmarried, or separated due to death, and more often afflicted by emotional disturbance, alcohol$1 \mathrm{sm}$, eniminal behavior, and physical or mental 111ness. Their mode of interaction was more often hostile or Indiflerent than in adequate families, and their discipline less consistent.

Reckless and Denitz, in their studies on differences between delinquents and nondelinquents, learned that the nondelinquent fielt hls parents were concerned 
about him and that hls famlly was as good as any other. I0 The parents of these boys took an interest in their sons and were satisfied with the friends chosen by their sons. Nondelinquents were more $11 \mathrm{kely}$ to Identify themselves with the community in a positive way, possibly due to the strong emotional bond between the child and his parents, the primary transmitters of soolal standards. Reckless and Denitz' findings lndicate that the child has a desire to emulate his parents' behavior and standards, which he then 1nternalizes. Delinquents, they found, do not have this attachment so do not have the same sense of responsibility to the community.

Kvaraceus has devoted much research in defining differences between delinquents and nondelinquents. In the area of family and home ilfe, he learned that delinquents usually come from homes with standards that vary from those of general soclety. 11 The 1nterpersonal pelationships in the family

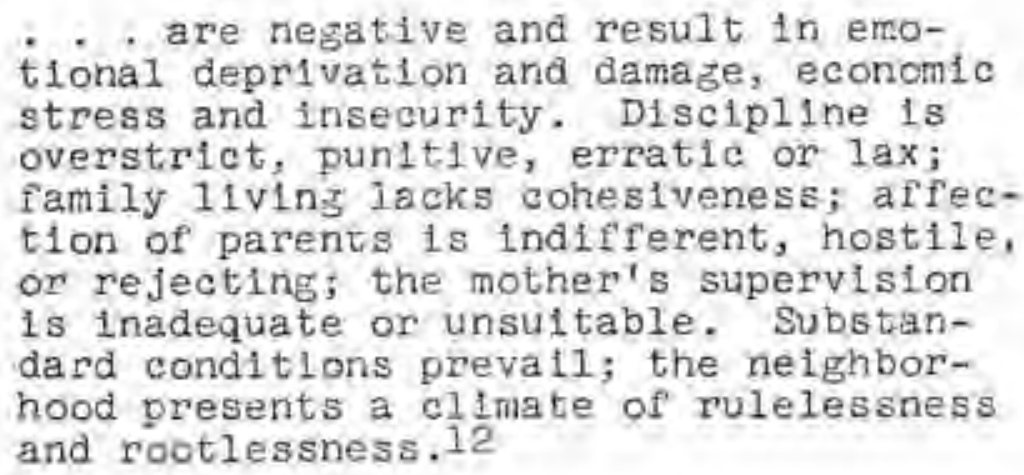


Kvaraceus found that the youth himself of ten exhlb1ts such tralts as amblvalence toward authorlty, high deflance, emotional fluctuation, high self-concern but Low self-concept, and a low frustration tolerance.

In the following sections, the concepts of authority, peer relationsh1ps, and self-concept w111 be discussed in more detall in order to relate them to the treatment process for the Juvenile.

\section{Authority}

A general definition of authority offered by Lasswell and Kaplan 1s "that use of power which has been legitimized in the institutional structure of soclety."13 The Gluecks have found that attitudes toward authorlty "concern basic ways in wh1ch the 1nd1vidual establishes his place, his security, and his share in society and in life." 14 They emphasize the Importance of attitudes towards authority, which most youth experience first through their parents, and later through soclety's agencles, such as church or school. A reconclliation with authority 1 s crucial to the development of the adolescent who is simultaneously achleving independence. The youth whose oontacts with authority have been negative or hostile needs contact with authority figures who are consistent and under- 
standing in order to work out his conflicts. These conflicts center around the youth's need to be independent of parental dominancy, hence his increased rebelliousness and rejection of their values. At the same time, however, the youth is seeking his own set of values to further solldify his ldentity, and needs adults with sound values with which he ean ldentify without feeling that he is saciflclng his independence. A constmotive relationship with an authority flgure allows a chlid to meet his dependency needs while developing his consolence, his own means of selicontrol. Self-control is developed when the child is still in a dependent relationship with the parental authority flgure, who definee limits for the child and helps him with the control of his 1mpulses. Falsberg suggests three ways in which the chlld develops selfcontfol:

1. The giving up of infantile pleasures to gain love and security.

2. Consclous and unconsclous 1dentification with and imitation of parental flgures.

3. Incorporation of parental and later community standards. 15

This suggests that dependent, neglected, and delinquent children experience more conflict with authority and thus Inoreased dif'lculty in developing self-control. 
Falsberg attributes this increased conflict to factors such as the absence of one parent, the unsultablilty of role models, the lack of emotional avallability of the parents, and the conflicting standards of the child's fam1ly with those of the larger soclety. 16 For these children, falr and consistent discipline and firm limits are essential, coupled with a nonpunitive authority figure to help the child handle his feelings toward authority and to find socially acceptable outleta for his 1mpulses,

\section{Peers and Self-Concept}

As we have sald earlier, adolescence is the stage In which the child develops physically, psychologicaliy, and socially into an adult. As the adolescent beginz the tasic of foming a meaningful Identity the peer group becomes his major vehicle. By conforming with his peers he receives a sense of belonging and the support needed for change. The peer group helps guard against the dangers of self-diffusion by providing an opportunity for self-testing, ego growth, 1dentity formation and self-esteem. Thus, the peer zroup becomes the adolescent's major reference group, that group irom which he learns his standards, values and goals. 
Barron sees the roles in the peer group as a "powerful determinant in the formation of the child $\mathrm{s}$ conception of himself."17 A role is defined as that behavior which an Individual assumes according to the position he holds in a particular group. 18 Cavan notes that self-concept develops from the adolescent's perception of what others, in particular his peer group, think of him, ${ }^{19}$ Thus one's self-concept ean be positive or negative, dependent upon the esteem w1th which the ahild feels himself held in his peer group. These feelings of being valued or of being worthless are incorporated into the ohlld's Ident1ty and are known as his self-esteem. Fallure to develop a strong self-concept and positive sense of self-esteem can result in ldentity diffusion. Reckless and Denitz, in their studies on the relationsh1p of self-esteem to peer group, learned that non-delinquents belonged to reference grougs that defined themselves as good, and that these boys were satisfled with their own self-1mage. This supports Sorenson's theory that alienation from society, through 1nst1tutionalization or segregation of delinquents, merely compounds the youth's problems by Ilmiting contacts with non-delinquent youths and adults, contacts which are essential to positive ldentity formation. 20 
The adolescent brings to the peer group attitudes and behaviors which are then reinforced, modifled or changed as the individual assimilates group practices and norms of his own. The adolescent's att1tudes are thus a mixture from past experiences, norms of his peers and minor reference groups such as fam1ly, church, or school. In a treatment home then, the peer group can be a valuable tool for rehabliltation or it can be a hindrance, depending on the values of the group.

Konopka states that status among one's peer sroup means more to the adolescent than status among adults. 21 In view of this, a treatment center must focus on the peer social structure in addition to individual casework. Polsky supports this finding in his research of Cottage S1x: "The position and status of each boy within his living group proved more important than acceptance by professional stati'."22 This research 11 lustrates the theory of differential association, which holds that delinquents learn their standards and norms of behavior from azsociation with each other or isolation from nondelinquent standards. In view of the Importance of the peer group to the formation of the adolescent's values, Polsky stressed community based treatiment in order to prevent segregation of delinquents from nondelinquents. 
The Treatment Home

Although Keller and Alper malntain that placement In group homes is not exactly formal treatment, they agree that many chlidren can make extensive social and emotional adjustments from $11 \mathrm{v} 1 \mathrm{ng}$ with accepting, adults and w1th the support of peers. 23 The group home that does provide treatment must provlde certain experiences and controls, which include:

1. A group IIving experience in a familylike atmosphere that also provides opportunity to develop peer relationships.

2. An opportunity for 1dentiflcation and warm relationships with adult author1 ty figures.

3. A favorable olimate in which physical and emotional needs are met and deviant behavior may be tolerated.

4. Ordered patterns of dally 11ving experlences which provide routines and control.

5. An opportunity for counseling, or to have someone 11sten to the ohild's needs and fears.

The group home provides a setting in which everyday Ilving experiences can be examined and modifled through the support and reedback of peers and houseparents. The group provides an opportunlty for trylng out new roles, skills, and 1deas, and for learning new ways of relating and expressing feelings. The group members 
can also learn the way others see and respond to their behavior and thus the consequences of their behavior. 24 In addition the group home provides the ehildren with a feeling of belonging to something. This is especlally important during adolescence because one of the developmental tasks is to become independent of the fam1ly and establish ties with others outside the home. Peers can offer substitution for the loss of parental support while they also can offer a group ldentity to the adolescent whose individual Identity is st111 developing. Living in a group situation which glves the adolescent support of peers has proven to be a less stressful situation than living in a foster home without benef1t of peer support. Adolescents are frequently unable to tolerate close one-to-one relationships with adults, who symbollze authority and dependency to the struggling youth. Support from peers helps him accept adult control as well as change his antisoclal and anti-authority att1tudes through group process. 25 Furthermore, group pressures from peers can help prevent an adolescent from making extreme emotional demands on the adult.

Att1tudes towards authority can be greatly altered through a satisfying relationship with adult parental substitutes. The houseparentg must offer security and 
guldance as well as affection. Feellngs of belng loved and accepted enable the adolescent to develop the trust necessary to 1 dentify with adult values and standards. Opportunity for 1dentification with adults helps the child find stability in his own identity as he lntegrates certain values and norms into his own developing system. Furthermore, the provision of a model of marrled and family life still proves to be the best means of fllling the normal developmental and socialization needs of the child while providing a stable model with whlch to ldentify.

Houseparents also need to provide a favorable atmosphere where the child f'eels secure in that his physical and emotional needs will be met. A favorable climate is one in which the child feels respected and understood as an Individual, knowing that he has someone to help hlm work on present problems as well as future goals. It 1ncludes protection and guldance of the child in controlling impulsive behavior until he is able to control himself. A most limportant aspect or a favorable climate for the growth of children is reasonable tolerance of deviant behavior by adults, without a punitive or rejecting attitude. Repression of such behavior does not allow it to be dealt with and 
may produce outer conformity rather than Internalized change. 26

Adult attention and affection as well as the planning of recreational and leisure time activities should not be based on the child's behavior. These are rights rather than privileges in a therapeutic climate. Fritz Redl compares the withholding of these rights from the needy ohlld to withholding medicine from a sick ch11d. 27

The Ch1ld Welfare League of America stresses that routines and regulations are necessary in a group I1VIng sltuation to provide a sense of cont1nulty, regularity, and stability, as well as to help simplify living for the child. ${ }^{28}$ A routlne schedule delays certain gratiflcations, this teaching the child selfcontrol. Ordered patterns of dally living experience help the oh1ld to become aware of what he can expect and on what he can depend, thus lowering his anxiety. Well def'ined limits, controls, and pre-determined consequences of their violation are necessary so that the child knows what is expected of him and can fulfill them. During adolescence the chlld must cope with new developmental tasks, unresolved maturational donfliets, and phys $\operatorname{lol} \log 1 \mathrm{cal}$ changes. This is diffloult without external and substitute controls such as rules, rou- 
tInes, and the presence of authority flgures, since the ego is still integrating its coping skills and the consclence is st111 developing. ${ }^{29}$

A final component in the effective treatiment home Is the avallability of understanding adults who have the time to ilsten to the concerns of the childrem. Jarvis, in a study of delinquent boys, found that elghty-five per cent of the boys felt that the best therapy for them was having someone I1sten and talk to them. 30 other cholces were having money, having an adult engage in some activity with him, thinking things out for himself, and finding actlvities for himself. Houseparents can also provide on-the-spot counselling In a crisis situation which may ward off further problems by allowing the chlld to ventllate his feelings and helping him understand his emotions. An opportunity for group meetlags in which bottled-up da1ly living pressures can be dlscussed openly also helps vent frustrations and hostlle feelings that may have been expressed through antisocial acts.

From the review of the ilterature, we found that Juveniles who are classified as delinquent tend to possess negative attitudes towards authority flgures and the community represented by them, and that they frequently have poor self-concepts. We also learned 
that peer relationships have a substantial influence on the juvenile's attitudes towards himself and others, even more influence than most adults. For example, a juvehile whose peer relationships are based in a delinquent subculture w1ll tend to adopt delinquent attitudes.

Thus it seemed that in a treatment program that attempts to change attitudes in the direction of conformity to society's accepted norms, changes in att1tudes towards the following varlables would be necessary: authorlty flgures, the Juvenlle's surrounding community, his self-concept, and relationship with his peers. 
FOOTNOTES - CHAPTER II

1. R. J. Hav1ghurst, "Developmental Tasks and Educat1on" In Theorles of Adolescence, Rolf E. Muuss, ed., Random House, New York, 1968, p. 109.

2. Roy Sorenson, "Youth's Need for Challenge and a Place in Soclety," Chlldren, Vol. 9, No. 4, JulyAugust, 1962, p. 27 .

3. Erlk H. Erlckson, "Ident1ty and the Ilfe Cycle," In Psychologlcal Issues, Vol. 1, No. 1, 1954, p. 91.

4. Bernice M. Moore, Juvenile Delinquency: Research Theory, and Comment, Washington, D.C., Assoclation for Supervision and Curriculum Development, 1958 , p. 28 .

5. Hyman S. Ilppman, "Preventing Delinquency," Federal Probation, (March, 1953), from Oisela Konopka, Group Work in the Institution, Assoclated Press, New York, 1954, p. 192.

6. Institutions Serving Delinguent Chllaren - Gulaes and Goals, U.S. Governinent Printing orrice, Washington, D.C., 1957, pp. 3-5.

7. OIlver J. Keller and Benedict S. Alper, Halfway Houses, Heath and Lexington Books, Lexington, Mass., 1970 , p. 107.

8. Oregon Juven1le Law Handbook, Oregon State Bar, Oregon, 1970, Chapter 9, section 3B.

9. Sheidon and Bleanor Glueck, Unraveling Juvenile Delinquency, Commonweal th Fund, New York, 1950, from Milton L. Barron, The Juvenile in Delinquent Soclety, AIfred A. Knopf, New York, 1955, p. 81.

10. Futh Cavan, Juvenile Dellnquency, J. B. Lippincott Co., Phlladelphia, Pa., 1969, p. 391.

11. WI11lam C. Kyaraceus, Juventle Delinquency, Nat1onal Education Assoclation, Washington, D.C., 1958, p. 12.

12. Ib1a, , p, 12. 
13. Harold LassweIl and Abrenam Kaplan, Power and Soclety, Yale Universities Press, New Haven, Conn., 1950 from Ell1 ot Studt, "An Outline for Study of Boclal Authorlty Factors in Casewark, " Soc1al Casework, Vol. 35, No. 6, (June, 1954), p. 231.

14. Sheldon and Eleandr Glueck, Family Environment and Delinquency, Houghton-Mifilin Co.2 Boston, Mass,, 1962, p. Q1.

15. Martin Falsberg, "Setting Limits With the suventle Delinquent," Soclal Casework, Vol. 38, No. 3, (March, 1957), p. 139.

16. Ib1d., p. 139.

17. Milton L. Barron, The Juvenile in Delinquent Soclety, Alfred A. Knopf N New York, 1955, P. 154.

18. Bruce T. Biddle and Edwin J. Thomas, Role Theory: Concepts and Research, John WIIey and Sons, Ino., New York, 1966, p. 135.

19. Ruth Cavan, op. e1t.: p. 276 .

20. Roy Sorenson, op. c1t., p. 27.

21. G1sela Konopka, op. c1t., p. 195.

22. Howard W. Polsky, Cottage S1x: The Soclal System of Delinquent Boys 1n Residentlal Treatment, Russell Sage Foundation, 1962, p. 167.

23. ollver T. Keller and Benediot S. Alper, op. elt.; p. 90 .

24. Heory Maler, Group Work As a Part of Resldential Treatment, National Assoclation of Soclal Work, New York, $1965, p, 28$.

25. Keller and Alper, op. olt., p. 81 ,

26. Chlid Welfare League of America Standards for Services of Child Welfare Institutions, Child Welfare League of Amer1ca, New York, 1963, p. 5.

27. Fritz Red1 and David Wineman, The Aggressive Chlld, Free Press of Glencoe, Ine. New York, 1957, pp. 35-36. 
28, Child Welfare League Standards, op. c1t.s p. 5.

29. Fritz Redl, op. olt., p. 110.

30. Richard Jarvis, "Dynamic Treatment Metbods," an address delivered at Juvenlle Court Institute, University of Oregon, Eugene, Oregon, August, 1963, In Alan, et. al., Use of the Depth Interview In Examining Attitudes of Delinquent Boys: An Exploratory Study, unpublished thesis, School of Social Work, Portiand State University, Portiand, Oregon, 1964 , p. 81 . 
CHAPTER III

METHODOLOGY

This research attempted to test the guiding hypothesis that "Juveniles who had been in the attention home would show a positive change in their perceptions and attitudes towards themselves and their community after a stay of two monthi," and to study the interrelations of attitudes and perceptions which might be useful in program development, treatment or understanding of change factors. The research hypotheses were:

1. There is no difference in scores on the Asocial Index between Time I and Time II (two months after entrance).

2. Time II scores are more favorable than Time I scores.

The main variables in this study were response: in the areas of authority, commulty, self-concept, peer selations and the prosram of the attention home, together with sectors measured by the Jesness Inventory, which ineludes a combined Asocial Index explained. in more deta11 later in the chapter.

Population Stualed

The population to be studied was originally to cons1st of all juvenlies who entered the attention hope 
and remalned at least two months, within the ten month perlod of data collection. Juveniles whose stay in the Home was limited to overnight or to only a few days were not Included.

However, certain problems encountered during the study necessitated a change in sampling units. The Home has a capacity for no more than elght youths at a time, and several youths remained in the Home for periods of up to $81 x$ months. Six youths had entered the Home before the onset of data collection, resultIng in their exclusion from Times I and II comparisons. Due to the small number in the Home during the period of data collection, it was declded that all youth would be given the Jesness Inventory at entry and every two months following. This meant that some fuveniles were excluded from the Times I and II samples, but were ellgible for Times III, IV, and $V$; that $1 \mathrm{~s}$, after four, s1x, and elght months' stay respectively. The researchers hoped this would inorease possibilities for wider comparison and analysis of data; however, little more data was colleoted in spite of this adaltion to our original design. The population actually studied consisted of s1xteen Juveniles who had taken either the Jesness Inventory or the Attitude Queationnaine, or both. The following 11st presents the numbers avallable for anat- 
ysis, by time and instruments. This total included aIl of those entering and staying more than two days in the study period.

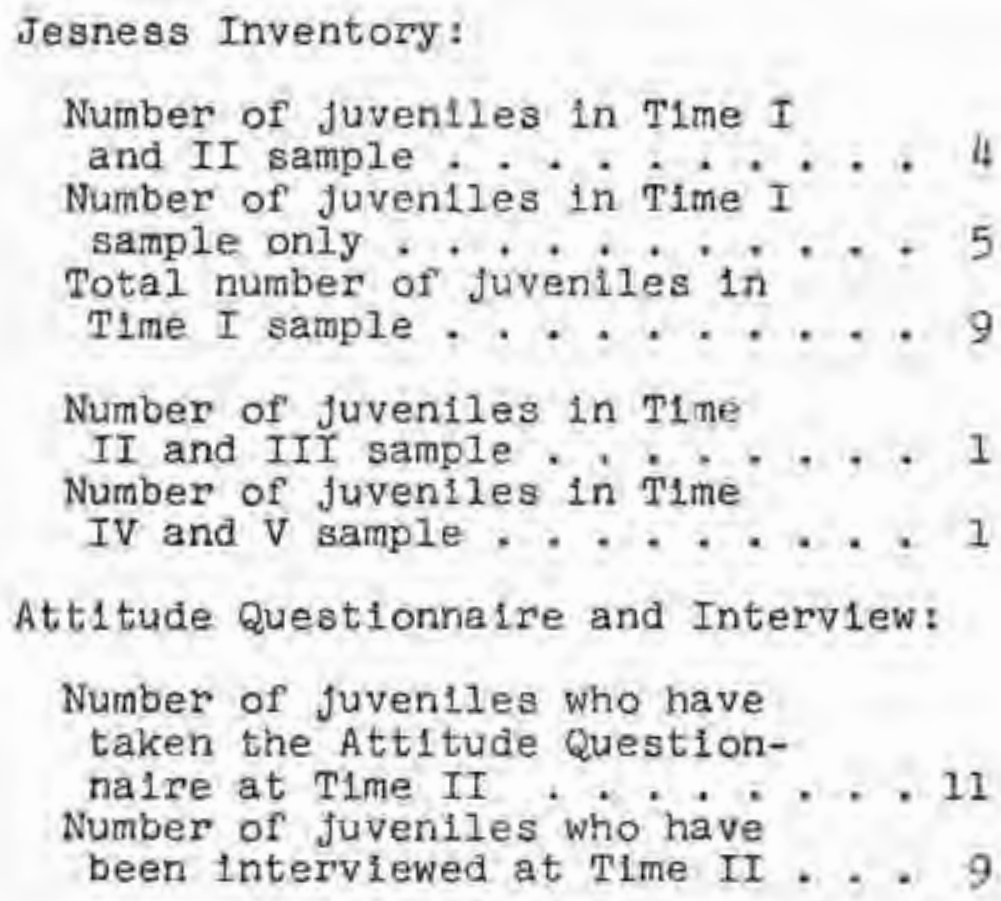

Att1tude Questionnalre and Interview:

Number of Juventles who have taken the Att1tude Questionnalre at Time II ........ II Number of Juveniles who have been intervlewed at Time II ... 9

Instruments of Data Collection (see Append1x 8)

Jesness Inventory. In choosing an instrument to measure attitude change, it was necessary to look for a test in which the rellability level insured that differences in results were not due to differences in responcing to the test ittelf, and which had been standardized for adolescents. The Jesness Inventory a structured questionnaire consisting of one hundred fifty-flve True-False items, is designed to measure attitude change over time in chlldren of both sexes between the ages of eight to eighteen years. The In- 
ventory is multi-dimensional for use in classifying both delinquents and nondelinquents through inclusion of 1 tems investigating areas of attitude and sentiment about self and others. The 1 temis included provide a single index of asocial tendencies predictive of delinquency; thus it is an instrument which can be used to distinguish delinquents from nondelinquents. It is Important to point out, however, that the Asocial Index Intends to measure psychologleal disposition only, and does not include soclai-environmental dimensions of delinquency such as lack of opportunity, lack of environmental support, family conflict and stress, and peer pressures.

The Asocial Index, one of eleven scales which represent separate personality characteristics, may be def'ined as a generalized tendency to resolve problems in social and personal adjustment or to behave in ways which vlolate established social norms and customs. There are two components to this index; the furst belng a motivation towards the goal, measured in the Soclal Maladjustment Scale. The second, consisting of seven of the nine remaining scales, is an lahibitory tendency related to an awareness of consequence, conflicting motivation, a generalized tendency ta inhibit need gratification or 1mpulse expression or lacompatible aelf 
doncept. The Asocial Index is Soctal Maladjustment:

minus the fribitory tendencies measured by seven scales.

The remalning scales and thelr deflnitions are as

follows:

Social Maladjustment. (63 1tems) A set of attitudes associated with unfulfilled needs, especially dependent needs, parental rejection, punitive or inconconsistent modes or reinforcement. Th1s set of attitudes is defined by the extent to which the Individual shares the att1tudes of persons who demonstrate inabllity to meet, in socially approved ways, the demands of their environment.

Value Orientation. (39 1tems) Refers to a tendency to hold values character1stic of persons in the lower soclal classes.

Irmaturity. ( 45 1tems) The tendency to display attitudes and perceptions of self and others which are usual for persons of a younger age.

Aut1sm. (28 1tems) A tendency in thinking and percelving to distort reallty according to one's personal desires or needs.

Allenation. (25 itema) Refers to the presence of distrust and estrangement In a person's attitudes towards others, especially towards persons representing authority.

Man1fest Aggression. (31 1tems) Refers to an awareness of unpleasant feelings, especially of anger and frustration, a tendency to react readily with emotion, and percelved discomfort concernini the presence and control of these feelings. 
W1thdrawaI, (24 Items) Involves a percelved lack of satisfaction with self and others and a tendency toward passive escape or isolation from others.

Social Anxiety. (24 1tems) The percelved emotional discomfort assaclated w1th interpersonal relationships.

Repression. (15 Items) Refers to the exclustion from consclous awareness of feelings and emotions which the Individual normally would be expected to experlence, or his rallure to label these emotions.

Dental. (20 1tems) Refers to the fallure to acknowledge unpleasant events or aspects of reality normally encountered in daliy $11 \mathrm{v}$ Ing.

Attltude Quest1onnalre (see Append1x B). A second instrument was devised to measure the attitudes towards authority, community, self-concept, peers and the Next Door, Inc.'s program. Th1s 1nstrument is a questlomalre designed to reveal attitudes towards more speclfic, concrete areas whereas the Jesness provides data on general, underlying attltudes.

The Attitude Questionnalre consisted of two parts, the first of which were eight olosed response questions concerning the major variables of this study. The questions in this section were concerned with learning what kinds of juveniles were actually in the ffome, 
and what feelings they had about themselves, the $1 \mathrm{r}$ peers and the houseparents, as well as the communt ty and authority figures.

The second section of the Att1tude Questionnalre consisted of a series of three Semantic Differential Scales designed to obtain a rating of each juvenile's attitudes towards selected concepts. Responses toward the Next Door, Inc. as well as towards the selected concepts of authority and the juvenile's self-concept, were rated on this scale. Attitudes towards these concepts were rated on a scale which consisted of twelve words and their opposites, These words were selected for their evaluative, potency, or activity connotations. Each word and 1ts opposite was placed on a continuum, w1th seven sectlons between the two words. For example, the flrst words of the scale were "helprul/ unhelpful," and looked like this:

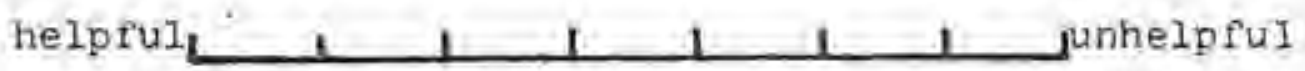

The seven sections between the two words represented degrees of meaning, such as "very helprul," to "very unhelpful." The juvenile marked an " $x$ " in a section of the continuum that best desoribed hIs feeling towards the concept being rated with respect to the particular word. 
S1x words and their opposites were considered to be evaluative; these were helpful/unhelpful, valuable/ worthless, nlce/awful, clean/dirty, good/bad and hot/ cold. Thus, a juyenlle who rated the concept "authorlty" very highIy on the evaluative words, that 1s, if he marked an " $\mathrm{X}$ " very near the left end of the continuum, would probably feel that authority and representatives of authorlty are generaliy holpful to him and worthwhlle in his life. A low scoring subject would probably feel that authority figures are unhelpful, that 1s, more trouble than of help on use to him, something to be avolded.

Potency words, which were large/small, strong/ weak, and deep/shallow, dealt with the powerfulness of the concept or 1 ts percelved ability to be effectlve and of influence in the juvenile's or others' 11ves, Activity words, noisy/quiet, fast/slow, and actlve/passlve, connote feelings of energy, 1ndustriousness and readiness to act. Thus a subject scoring high on activity words on the concept "self-concept" would percelve himself to be an active and energetic person rather than passive, lazy, and stagnating or 1die.

Interview. Recognizing that the test data would possibly prove inadequate due to our small sample size, 
an 1n-depth interview was also administered by the researchers to eleven of the Juveniles in the sample. The purpose of this interview was to collect certait 1dentifying Infomation as well as the Juveniles' perceptions and subjective opinions regarding such areas as his placement in the home and the effectiveness of the home. Areas Investigated included the Juvenile's perception of the reasons for his placement in the home, kinds of Juveniles placed in the home, and of how others viewed the home. Quality of peer relationships and of relationship to the houseparents, with suggestions for improvements in these areas, were also el1c1ted.

\section{Collection of the Data}

The Jesness was orlginally administered by the Coordinator of Volunteers for Hood River County to each juvenile upon entrance and at subsequent two month intervals. The researchers chose a volunteer with no direct involvement with the juveniles in the Next Daor, Inc. to avold contamination of test results. After several months it was necessary for the houseparents to take over the adminlstration of the test due to the volunteer's difficulty in arranging her time. Most likely this ald not blas the test since there was a 
bullt-in fake ability scale which checked the veraclty of the individual's responses. The houseparents told all Juveniles that their tests would remain confldent1al and that only the researchers would see their responses. The test was given to the juveniles at the Next Door, Inc. to make it as convenient as posaible for the Juventles.

After a Juvenile had been in the Home for a perlod of approximately two months, the researchers went to Hood River to administer the Attitude Questionnalse and to conduct a personal interview with each juvenile, Eleven Juveniles took the Attltude Questionnalre and nine of these eleven also were interviewed.

Analysis of Data

Base Data. Thirty-six juveniles were placed in the Home between the periods of November 15, 1971 (when the Home opened) to December 31, 1972 (when the study was concluded). Base data was collected on these youths in order to complie a flow chart. Data included the age and sex of each fuventle, reason for referral, number of days each juvenile spent in the Home, and placement upon release.

The above information was organized in Table I according to the order in which the juvenile came into 
the Home. This organization enables the reader to Identify changes in other variables, such as days in Home or placement upon release, and their relationship with the relative data of the Home's program.

The mean, average deviation and standard deviation of the number of days the juveniles spent in the Home was also computed, excluding the five juveniles who remained in the Home at the conclusion of this study.

Tables presenting the exact number of juveniles referred to the Home for specifiled reasons and the number of juvenlies placed in their own home, or specified altennatives to the $1 \mathrm{r}$ home, were also compiled.

It was determined that during this same time perlod of November 15, 1971 to December 31, 1972, forty-elght youths were detalned in the Hood Rive: County Jall overnight on longer. Reasons for each Juvenile's detainment were ldentifled and presented in Table IV for comparison with simliar data on juveniles placed in the Horne.

Jesness Inventory. The four sets of Jesness Inventory scores for Times I and II were evaluated an each of the eleven scales by the two-tailed test of 
related means to determine whether changes in scores from Time I to Time II were significant at the .05 level, thus testing the null hypothesis. W1th the null hypothesis rejected, a one-talled probability was applied to determine the signifleance of change with respect to the expected direction. The mean scores of the population and varlation in scores were computed by flnding the mean and standard deviations for the four palrs of scores on all eleven scales. Raw scores for the Jesness were welghted, tabulated and converted into standardized $T$ scores with a midpoint of fifty and each standard deviation equaliing ten points. The norm far the nondelinquents on whom this test was standardized is a I score of flfty, with a range from forty to sixty.

Individual scale changes for each juvenlle were scrutinized to determine in what areas and in what direction the most changes occurred.

The mean values on aII scales for the seven male entrance scores were computed and examined for population description. The two female entrance scores were omitted due ta lnsufflcient $\mathrm{N}$ and the lesser rellablitty of the Jesness scales with female pop- 
ulations. I These seven scores were compared on each scale to seven random scores of adolescent males from a similar group home in a nearby county. This was done by computing the means and standard devlations on al1 scales for each population, and applying a two-talled $t$-test to determine if differences in scores were $\$ 1 \mathrm{~g}$ nirfcant.

The Asocial Index scores of the six pairs of Juvenlles who took the Jesness more than once were tested for significant difference by comparing first and last test scores for each youth regardless of the time span elapsed between the testing. Agaln the mean and standard devlations on each scale were computed for ali subjects in group I (11rst-time scores) and all subjects in group II (last tlme scores). A two-talled t-test was then applied to determine if diflerences in scores between group I anc scoup II were significant.

I There is slightly more difficulty in alstingulshing female delinquents from nondelinquents as thelr dilferent base rate in the general population presents a more difficult prediction problem. However, on most scales the distribution of scores for the two groups, male and female, do not dif'ter despite the fact that the scales were developed from a male sample. A separate discrimlnate analysis was rut for the female sample, produsing a formula of dif'erins weights for each scale and a smaller coristant factor, which resulted in a prediction of about $85 \%$ accuracy. Carl $F$. Jesness, The Jesness Inventory, Californla Youth Authority, 1953, p. 21 . 
Attitude Questionnalre. Each of the elght questions of this questionnalre were analyzed separately to determine frequenoy in each response category and general direction of response of the total sample. Quest1ons 1 through 3 have five response categorles which were assigned numerleal ratings from one to five, with five representing the most favorable or positive response, Questions 4 through 8 were rated on a seven point scale, with seven being the most positive response, Whenever applicable, selected scales of the Jesness were related to questions from the att1tude questionnalre, although no attempt was made to show statistical correlations.

Semant1c Differential Scale. The responses

towards the selected concepts were rated on a seven point scale with respect to each word. Seven was the hlghest or most favorable response and one was the lowest, or least favorable response towards the concept , being rated. Since there were six "evaluative" words, six times seven points, or forty-two was the highest score obtainable on this factor. An index was complle! for this factor by dividing the total points achieved by forty-two, the total points obtainable. As there were three words each on the activity and potency fac- 
tors, the highest score was three times seven points, or twenty-one points. Thus, an index was computed by dividing the total number of points obtained by total number of points obtainable (twenty-one points). In th1s way, each Index for each factor 1 equal to 1.00 when the highest score 1s obtained, allowing us to make comparisons between raw scorea for each of the factors, evaluative, potency, and activity.

Raw scores for each factor were presented for each concept rated, ranked in order from highest to lowest so that the distributions of scores could be readlly seen (see Tabies XI-XIII). Scores for the evaluative and potency factors on "Authorlty" and the "Next Door, Ine." and "Self-concept" were numertcally ranked so that comparisons could be made as to how each Juvenile responded to these.

A rank correlation was run between those concepts considered most likely to have a significant correlation. These were "Authority" and the "Next Door, Inc." on the potency factor, and "Se1f-concept" and the "Next Door, Inc." on the potency factor,

A great anount of data were collected but not analyzed due to time limitations. Further analysis would be useful, particulaniy in connection with an ongoing research. 
CHAPTER IV

\section{FINDINGS}

Four separate but related measures were used to measure attitude change in juveniles placed in the Home and to determine, Indirectiy, how well the Home's program was meeting 1 ts declared goals. These measures also almed to discover possible factors in the relationships of the Home, youth and community.

The Jesness Inventory was the measure used as a standardized base of comparison. An Attitude Questionnalre of a structured, closed-response nature and a differentlal word response test, the Semantic Differential, were also administered. Finaliy, the juveniles were intervlewed with a set of questions, constructed from literature indicating them to be of significance, with open-ended responses. The findings from these measures w111 be reported in that order, preceded by base data on the juveniles placed in the Home.

During the perlod of Novernber 1.5, 1971 through December 31, 1972, thirty-six youths were placed in the Next Door, Inc, of these Juveniles, twenty-two were males and fourteen females, ranging from ten to seventeen years of age. The mean age was 15.2 years. 
Table I presents an overall flow chart of a11 juveniles In the Home during this perlod, their ages and sex, reason for referral to the Home, placement upon release, and number of days each juvenile spent in the Home.

\section{TABLE I}

FLOW CHART OF JUVENILES IN THE NEXT DOOR, INC., FROM NOVEMBER 15, 1971 - DECEMBER 31, 1972

\begin{tabular}{|c|c|c|c|c|c|}
\hline $\begin{array}{l}\text { Juve- } \\
\text { nile* }\end{array}$ & Age & Sex & $\begin{array}{l}\text { Reason } \\
\text { for } \\
\text { referral }\end{array}$ & $\begin{array}{l}\text { Placement } \\
\text { upon } \\
\text { release }\end{array}$ & $\begin{array}{l}\text { Number of } \\
\text { days in Home }\end{array}$ \\
\hline 1. & 16 & M & 0 & 7 & 1 \\
\hline 2. & 13 & $F$ & B & 4 & 55 \\
\hline 3 . & 15 & $M$ & $\mathrm{H}$ & 1 & 1 \\
\hline 4. & 15 & F & B & 8 & Still in Home \\
\hline 5. & 15 & M & A & 1 & 2 \\
\hline 6. & 16 & M & E & 1 & 176 \\
\hline 7. & 16 & F & B & 2 & 116 \\
\hline 8. & 14 & F & B & 2 & 116 \\
\hline 9. & 14 & F & D & 1 & 14 \\
\hline 10. & 15 & M & D & 8 & St111 In Home \\
\hline 11. & 75 & $M$ & $\mathrm{E}$ & 1 & 114 \\
\hline 12. & 17 & M & B & 5 & 10 \\
\hline 13. & 15 & F & A & 4 & 69 \\
\hline 14. & 15 & $\bar{F}$ & $\bar{F}$ & 3 & 1 \\
\hline
\end{tabular}


TABLE I--Continued

\begin{tabular}{|c|c|c|c|c|c|}
\hline $\begin{array}{l}\text { Juve- } \\
\text { nile* }\end{array}$ & Age & Sex & $\begin{array}{l}\text { Reason } \\
\text { for } \\
\text { referral }\end{array}$ & $\begin{array}{l}\text { Placement } \\
\text { upon } \\
\text { release }\end{array}$ & $\begin{array}{l}\text { Number of } \\
\text { days in Home }\end{array}$ \\
\hline 15. & 13 & F & $\bar{F}$ & 3 & 1 \\
\hline 16. & 13 & F & $\bar{B}$ & 3 & 1 \\
\hline 17. & 15 & M & $A, D$ & 2 & 76 \\
\hline 18. & 17 & F & G & 1 & 2 \\
\hline 19. & 16 & F & E & 5 & 176 \\
\hline 20. & 14 & M & D & 1 & 22 \\
\hline 21. & 14 & M & D & 8 & St111 in Home \\
\hline 22. & 10 & M & E & 1 & 1 \\
\hline 23. & 17 & M & B & 2 & 26 \\
\hline 24. & 14 & $\bar{F}$ & A & 1 & 4 \\
\hline 25. & 16 & M & D & 1 & I \\
\hline 26. & 12 & M & D & 1 & 1. \\
\hline 27. & 17 & M & a & 2 & 1. \\
\hline 28. & 14 & M & F & 1 & 23 \\
\hline 29. & 16 & M & C & I & 1 \\
\hline 30. & 13 & M & c & 1 & 1 \\
\hline 31. & 14 & M & D & 8 & Stl1I in Home \\
\hline 32. & 13 & M & I & 1 & 2 \\
\hline 33. & 12 & F & A & 8 & 1 \\
\hline 34. & 15 & M & D & ह & $1 B$ \\
\hline
\end{tabular}


TABLE I--Continued

\begin{tabular}{|c|c|c|c|c|c|}
\hline $\begin{array}{l}\text { Juve- } \\
\text { n1le* }\end{array}$ & Age & Sex & $\begin{array}{l}\text { Reason } \\
\text { for } \\
\text { referral }\end{array}$ & $\begin{array}{l}\text { Placement } \\
\text { upon } \\
\text { release }\end{array}$ & $\begin{array}{l}\text { Number of } \\
\text { days in Home }\end{array}$ \\
\hline 35. & 15 & F & A & 8 & Stril in Home \\
\hline 36. & 13 & M & h & 2 & 5 \\
\hline
\end{tabular}

- Juvenlles are organlzed in order of admission.

CODE FOR REFEHRAL:

A Run away

B Foster home falled

C Vandalism

D Beyond parental control

E Family problems (1nadequate care, marriage problems, 111ness)

F Fun away from an inatitution

G Driving under the influence of alcobol

H Thert

I Driving without a license

- Unknown

CODE FOR PLACEMENT:

1. Returned home

2. Foster home 
3. Returned to institution

4. Ran Prom Next Door, Inc.

5. Placed in a group home

6. Placed with relatives

7. Unknown

8. Now $1 \mathrm{n}$ the Home

Mean days in Home -. 38.48

Average deviation -- 39.60

Standard Deviation -- 51.76

Table II shows where each child was placed upon release from the Next Door, Inc. Almost half (slxteen) of the juyeniles were returned home, one of the goals the Next Door, Inc. hoped to achieve. One purpose of the home was to provide a neutral place for the child unt1l the sltuation within the home or between the child and the parents could be improved. Six juveniles were placed in foster care through the efforts of a volunteer foster home finding service in Hood Rlver. 
TABLE II

PLACEMENT UPON RELEASE FROM THE NEXT DOOR, INC. (TOTAL POPULATION - 36)

\begin{tabular}{llllllllll}
\hline \hline $\begin{array}{c}\text { * See code } \\
\text { below }\end{array}$ & 1 & 2 & 3 & 4 & 5 & 6 & 7 & 8 \\
\hline \hline Males & 12 & 4 & 0 & 0 & 1 & 1 & 1 & $3=22$ \\
$\begin{array}{l}\text { Females } \\
\begin{array}{l}\text { Total both } \\
\text { sexes }\end{array}\end{array}$ & 4 & 2 & 3 & 2 & 0 & 0 & 0 & $3=14$ \\
\hline \hline
\end{tabular}

*Code Placements

I. Returned home

2. Foster care

3. Returned to institution

4. Ran from Next Door, Inc.

5. Placed in group home

6. Placed with relatives

7. Unknown (placement information not in file or file not available at this time)

8. Child not yet released

Table II shows the reasons the juveniles came Into contact with the juvenile court. Seven youths were referred for running away from home, six due to 
fallure of the foster home in which they were Ifving, and another seven were classifled as "beyond parental control." The smallest number (only one referral each), came to the attention of the court for offenses such as driving under the influence of alcohol, drivIng with no license, and theft.

TABLE III

REASON FOR REFERRALS - NUMBER CATEGORIZED BY SEX

* Same code as lor Table I

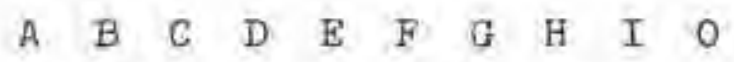

\begin{tabular}{lllllllllll}
\hline Males & 3 & 2 & 2 & 6 & 3 & 1 & 0 & 1 & 1 & 3 \\
Females & 4 & 4 & 0 & 1 & 1 & 3 & 1 & 0 & 0 & 0 \\
$\begin{array}{l}\text { Total both } \\
\text { sexes }\end{array}$ & 7 & 6 & 2 & 7 & 4 & 4 & 1 & 1 & 1 & 3 \\
\hline
\end{tabular}

Durling the period in which the Next Door, Inc. was opened, (mid-November, 1971) until this research was completed (December 31, 1972), forty-elght youths were detalned in the Hood Blver County Jall overnight or longer. Elghteen of these juveniles were from counties other than Hood Niver. Although the exact number of days each juventle was detalned is not available, It has been determined through court personnel 
that most stayed only a few hours or one day, unt11 parents could be contacted or the Home notified of the child's coming. Except for runaways, the reasons for referral to the County Jall were generally more serlous than reasons for referral to the attention home.

\section{TABLE IV}

JUVENILES DETAINED OVERNIGHT OR LONGER

IN HOOD RIVER COUNTY JAIL

November 15, 1971 - December 31, 1972

\begin{tabular}{lc}
\hline Reason for Referral & Number Referred \\
\hline Runaway & 14 \\
Minor in possession & 10 \\
Auto theft & 6 \\
V1olated arug laws & 5 \\
Larceny & 4 \\
Breaking and entering & 3 \\
Drunkenness & 2 \\
Protective custody & 1 \\
Vandalistn & 1 \\
Curfew & 1 \\
Ungovernable & 1 \\
Total & 48 \\
\hline
\end{tabular}


Table V is a bar graph Indlcating the number of days the Juventles stayed in the home. As Table I showed, the mean number of days was 33.48 , w1th a range from one to one hundred seventy-s1x days. The mean is rather large but this is accounted for by the elght Juvenlles staylng in the Hoine from fifty-flve days to one hundred seventy-81x days. The average deviation is 39.6, which means that on the average, the ind1v1dual scores deviated from the mean score of 33.48 by 39.6 days, Indlating that the range for planning is quite wide. About one-third of the juveniles remained In the home only overnight, another third less than a month, and one-third from two months to six months. This shows the variety of needs the home $1 \mathrm{~s}$ meeting in serving both long and short term juveniles, and limitations on treatment. 
TABLE V

DAYS IN HOME*

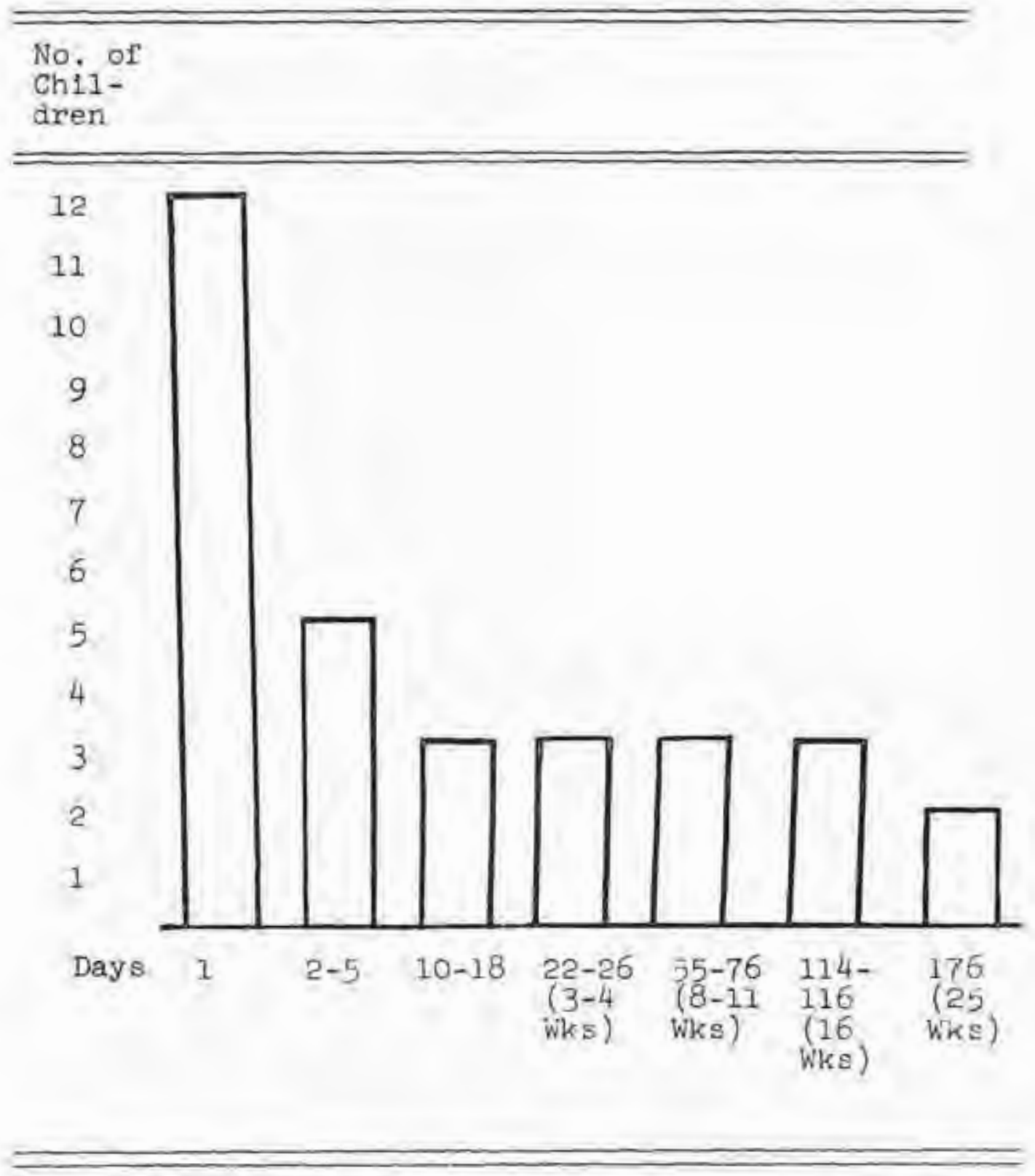

*This does not include the flve juveniles not yet released from the home wiren the study ended. 
The researchers intenviewed eleven juveniles for additional detalis that might be of interest. There were seven males and four females ranging from fourteen to seventeen years of age. Only one youth was not from a broken home: seven lived with their mother and stepfather; two with their mother; and one with their father and stepmother.

A11 but two had been in foster homes, three had been in one foster home, two juveniles in three different homes, one in four homes, and one had been in five homes, Of these eleven, only three were placed in another f'oster home, one went to a group home, three are still in the Home, and the remaining number (four) were sent to their own homes.

The majority of the parents of these eleven juveniles were blue collar workers, such as dam worker, lumber mill worker, painter, and mechanic, One mother supported her family by fruitplcking, whereas three others held service oriented jobs such as cashler and waitress.

Jesness Inventory

The main focus of this research was on the sample set of four juveniles who took the Jesness at Times I and II. An Increase or decrease in the Asoctal Index 
at the .05 level of signifloance would be sufflelent to reject the null hypothesis that there would be no ohange in attitudes of Juveniles under the type of treatment provided by the Next Door, Inc.

\section{T'ABLE VI}

TWO-TAILBD TEST OF STGNIFICANCE FOR RELATED VEANE FOR JESNESS SCORES AT TIMES I AND II

$$
(\mathrm{N}=4)
$$

\begin{tabular}{|c|c|c|c|c|}
\hline SCALE & $\bar{x}_{1}$ & $\bar{x}_{2}$ & $\underline{t}$ & $\mathrm{p}$ \\
\hline $\begin{array}{l}\text { Soc1aI } \\
\text { MaIadjustment }\end{array}$ & 65.75 & 71.25 & 1.859 & NS \\
\hline $\begin{array}{l}\text { Value } \\
\text { Orientation }\end{array}$ & 59.75 & 60.75 & .387 & NS \\
\hline Immaturity & 59.00 & 55.00 & 2.189 & NS \\
\hline Aut 1s:n & 63.00 & 65.00 & .805 & NS \\
\hline Allenation & 65.00 & 64.50 & .397 & NS \\
\hline $\begin{array}{l}\text { Manifest } \\
\text { Aggression }\end{array}$ & 53.75 & 55.50 & .504 & NS \\
\hline Wi tharawal & 53.50 & 58.50 & .851 & NS \\
\hline $\begin{array}{l}\text { Soctal } \\
\text { Anxiety }\end{array}$ & 51.25 & 47.25 & .876 & NS \\
\hline Repression & 61.06 & 59.69 & .041 & NS \\
\hline Denlal & 36.25 & 38.75 & .829 & ns. \\
\hline $\begin{array}{l}\text { Asoctal } \\
\text { Indez }\end{array}$ & 61.00 & 71.00 & 3.189 & $.050^{\circ}$ \\
\hline
\end{tabular}

* Slgniflcant at the ,025 level of confldence ton a one-tailed test. 
Upon entrance these four juveniles had a mean T score of 61.00 which is one standard deviation above the norral population for which the norm is 50. Compared with the nondelinquent sample, these four are in the elghty-f1fth percentile meaning e1ghty-five per cent of the nondelinquent population had scores of 61.00 or 1ess. After two months these juveniles scored at 71.00 , two standard deviations above the norm, and fell in the ninety-eighth percentile of the nondelinquent population. Table VI indicates that an increase In the Asoclal Index from 61.00 at Time I to 71.00 at Time II was found to be significant at the .05 level. The probability is one in twenty that this increase would occur by chance. However, due to the very small sample size the score of only one juvenile, who represents twenty-flve per cent of the sample, could skew the results. Thus, although the results are signiricant for these four Juveniles, they are not yet general1zable to outslde populations. A one-talled t-test found this ten point increase to be significant, although borderine, thus rejecting the null hypothesis and indicating that in these four cases, fuveniles tended to adont more delinquent abtitudes as measured by the Asocial Index. 
However, the t-test takes into consideration the uncertalnties of such a sinall number; the chances are better than ninety-seven out of a hundred that repeated sampling would produce similar results. A test reported later in this chapter corroborates a shift to more delinquent proneness, as do some studies elsewhere. Such a shift is of current concern to group homes in the State, and is only partially understood. The Asocial Index was constructed by statistical analysis which examined each of the ten inventory scales and then combined them to predict delinquent behavior. Asoclalization measures Soclal Maladjustment minus the tendencies toward inhibition of ant1soclal behavior, measured by the remaining scales. The Asoclal Index is one of the most stable scores on the test and is the least susceptible to change. Th1s leads the researchers to belleve that in these four cases the findings of the research are accurate. It should be noted that simflar increases in this index have also occurred in other group homes.

As shown in Table VI, no other scale scores showed a slgnificant difference from Time I to Time II. However, it shoula be noted that the Social Maladjustment score increased $s 1 x$ points, a factor which contributcd highly to the increase in the Asocial Index 
score since Soclal Maladfustment is double welghted in tabulation. In addition, all scales except two, Autism and Allenation, were from one to two standard deviations below the Soc1al Maladjustment score of 71.25 at T1me II. Th1s is of Importance because the Asocial Index is dependent upon the relative distance between Soclal Maladjustment scores and other scale scores. Thus, the lower the Inhibitory scale scores in relation to the Soclal Maladjustment, the higher the Asocial Index. Since Social Maladjustment refers to the extent to which one "shares att1tudes expressed by persons who show an inab111ty to meet in socially approved wayr, the demands of Ilving," it is possible that youths in the Home may have adopted att1tudes of a delinquent subculture during their stay.

H1gher scores in Value orientation are related to a tendency towards nonconforming, rule-violating behavior, lack of respons1b111ty, and an al1enated attitude towards adults. There was no signiflcant change in the scores from Time I to TIme II but the score was one standard devlation above the norm for the nondelinquent population, Indicating that these Juveniles hold values assoclated with the lower class culture. 
The Autism scale scove for both times was 1.5 standard deviations above the norm, indicating that these youths are more 1ikely than the normal population to distort reallty accoraing to their personal desires and needs. Item content indicates that

the high scorling individual sees himself as self-sufficient, smart, good-looking, and tough, while at the same time he expresses concern about "hearing things," feels there is something wrong with his mind, likes to daydream, prefers to be alone, is fearíl, and expresses many somatic complaints. The ploture is of a most inappropriate facade ố self-adequacy covering a very insecure person.

The Alienation scale, which measures hostility, showed similar results, with a T score of 65.00 . Again this soore is 1.5 standard deviations above the nom of fifty, indicating that there is an increase in the presence of "distrust and estrangement in relationshlps with others, eapecialiy with authority fisures."

Scores on the Immaturity scale were 59.00 at Time I and 55.00 at Time II, probably a normal variation rather than a sizhlficant change. These scores indicate that these fuveniles differ little from the normal population on this scale, which attempts to measure the extent to which the youth ralis to display those 
responses, attitudes, points of vlew and perceptions whlch are more common to a group younger than his own. Item content for this scale 1ndicates that high scorlng juvenlies tend to repress problems and lack 1ns1ght into their own and others' motivations, thus prove to be poor candidates for traditional psychotherapy. Man1fest Aggression, which measures aggression and anger, is highly scored when the Individual is concerned about controlling his feelings and is frustrated in his efforts to understand and feel comfortable with himself. Jesness cautions that there is not necessar11y a close relationship between a high score on this scale and angry temper outbursts or host1le/aggressive behavior, since the youth's concern over control of his feellngs may lead to overcontrolled behavior. As a whole, the composite score of the four fuveniles did not differ slgnifleantly from the nondelinquent sample on the Manifest Aggression scale.

The Soclal Anxlety score also showed little difference from the norm. Since high scorers tend to feel nervous tension and self-consclousness and to see themselves as sensteive to orlticlsm, we can assume from the mean score of the Juyeniles sampled that they do not have these tendencles. 
Withdrawal refers to

of satisfaction with self and others
by passive escape or 1 solation from
others. The Individual who scores
high percelves himself as depressed,
dissatisfled with hlmself, sad, mis-
understood, and although preferring to
be alone, feels lonesome.

The Time II score of 58.50 shows that there 1 s a smail tendency for this group as a whole towards withdrawal. but this score 1 s still within the norm range of forty through sixty.

The Repression scele also borders on the upper range of the norm, with scores of 67.06 and 59.69 . "The high-scoring subject does not admit to, or is not aware of feelings of anger, dislike, or rebellion, and is generally uncritieal of himself and others."

Scores on Denlal show a negative relationship with scores on most other scales. A high score inalcates a teridency to

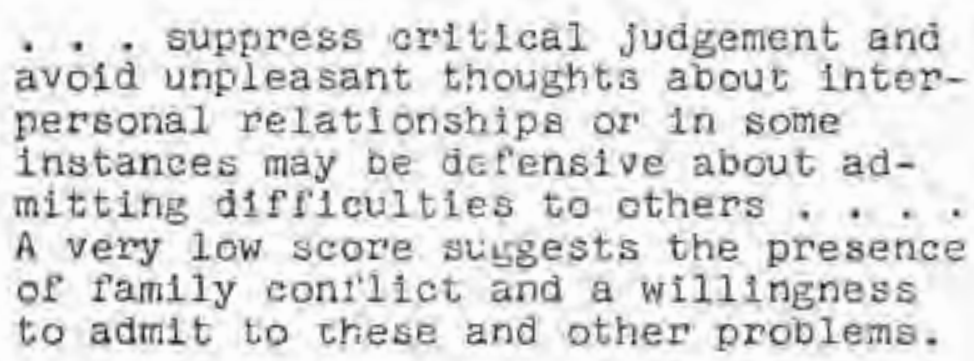

Thus a low score, such as 38.75 found at TIme II, would tend to Increase the Asoctal Index due to the deareased 1ribiting elfect of a decrease in derial. 
Analysis of Individual Cases. Increases and decreases in each scale were analyzed to determine whether there were conslstent trends in scale changes. For example, the reseavchers wished to learn if any scales, such as Allenation, showed a conslstent increase or deorease for all individuals. Such information would Indicate that the change in score, indicating a related change in attitude, was attributable to the Home's program wather than to individual differences. Table VII provides Time I and Time II scores on the eleven Jesness scales for the sample of $N=4$, two females and two males. Direction of change in scores of each scale $1 \mathrm{~g}$ indicated by an " $\mathrm{F}$ " (favorable) or "U" (unfavorable) in a column to the right of each pair of scores. S1x points was chosen as the cutting point for "conslderable increase." Any soore change less than six polnts was taken to be of negligible importance. 
TABLE VII

T SCORES FROM TIME I TO TIME II ON ALL JESNESS SCALES FOR $N=$

\begin{tabular}{|c|c|c|c|c|c|c|c|c|c|c|c|c|}
\hline \multirow[b]{2}{*}{ SCALES* } & \multicolumn{3}{|c|}{ Female } & \multicolumn{3}{|c|}{ Female } & \multicolumn{3}{|c|}{ Male } & \multicolumn{3}{|c|}{ Male } \\
\hline & $x_{1}$ & $x_{2}$ & $\begin{array}{l}\text { Direc- } \\
\text { tion** }\end{array}$ & $\mathrm{X}_{1}$ & $x_{2}$ & $\begin{array}{l}\text { Direc- } \\
\text { tion }\end{array}$ & $x_{1}$ & $x_{2}$ & $\begin{array}{l}\text { Direc- } \\
\text { tion }\end{array}$ & $x_{1}$ & $x_{2}$ & $\begin{array}{l}\text { Direo- } \\
\text { t1on }\end{array}$ \\
\hline$S M$ & 56 & 65 & U & 76 & 73 & $\mathrm{~F}$ & 64 & 70 & $\mathrm{U}$ & 67 & 77 & df \\
\hline vo & 59 & 58 & F & 61 & 56 & $\mathrm{~F}$ & 56 & 53 & U & 63 & 66 & If \\
\hline IMMI & 82 & 74 & F & 48 & 46 & B & 56 & 50 & F & 50 & 50 & $\mathrm{~N}$ \\
\hline AUt & 59 & 62 & Ut & 68 & 64 & E & 63 & 64 & $\mathrm{U}$ & 62 & 70 & $\ddot{U}$ \\
\hline$A L$ & 63 & 63 & $\mathrm{~N}$ & 66 & 62 & F & 66 & 66 & N & 65 & 67 & U \\
\hline MA & 47 & 49 & U & 62 & 55 & B & .55 & 57 & $U$ & 51 & 61 & U \\
\hline WD & $6 I$ & 79 & $\mathrm{U}$ & 67 & 76 & to & 47 & 50 & D & 39 & 29 & B \\
\hline$S A$ & 60 & 57 & F & 60 & 64 & U & 37 & 37 & $N$ & 48 & 31 & F \\
\hline REP & 77 & 74 & $\mathrm{~F}$ & 43 & 38 & $F$ & 38 & 44 & U & 50 & 44 & $F$ \\
\hline DEN & 35 & 32 & $\mathrm{U}$ & 38 & 40 & $F$ & 32 & 32 & $\psi$ & 40 & 51 & F \\
\hline AI & 54 & 71 & U & 72 & 74 & U & 58 & 67 & Ut & 60 & 72 & $\mathrm{U}$ \\
\hline
\end{tabular}

* Categorles are explained in Table VIII

* $*$ I $=$ Favorable

U = Unfavorabie

$M=$ No change 


\section{Case \#1 (remale)}

This Individual's scores Increased considerably In the Soc1al Maladjustment and W1thdrawal Scales, while there was a considerable decrease in Immaturity. The remalnder of the scales did not change a great deal. The Asoctal Index 1ncreased seventeen points showing a rise from the s1xty-sixth percentile to the ninetyeighth percent1le of the nondelinquent sample. This means that at $T_{1} s 1 \times t y-s i x$ per cent of the nondelinquent population had scores lower than this individual.

\section{Case \#2 (female)}

In this case there was a conglderable increase only in the Withdrawal score, and a considerable decrease in Manlfeat Aggression and Repression. There was no significant ehange in the Asocial Index probably due to the negliglble change in Soclal Maladjustment. The Asocial Index falls in the ninety-ninth percentile of the delinquent population meaning that this girI is within the top one per cent or the deIInquent population, highly delinquent in attitudes. 


\section{Case \#3 (male)}

Th1s 1ndividual showed a considerable increase in Soc1al Maladjustment, Value orlentation, and Represslon. The only index in which there was a considerable decrease was found in the Immaturity Scale. As in Case \#1, the Asoclal Index increased, showing a nine polnt increase to almost two standard deviations above the norm. This is an increase from the elghtleth percentile of the nondelinquent population to the ninetyelghth percentile.

\section{Case \#4 (male)}

Th1 a case had the largest varlance in both directions between scores. There were large increases in Soc1al Maladjustment, Autism, Manifest Aggression, and Denlal and large decreasea in W1thdrawa1, Soc1al Anxlety, and Repression. The Asocial Index Increased considerably but no more than in Case \#3. The percent1le in this case changed from the elghty-fifth to the ninety-ninth percentile.

The only individual whose score did not increase on the Social Maladjustment Scale also did not increase on the Asoclal Index. Th1s is probably due to the fact that the Soclal Maladjustment scale is the most signif- 
1cant in changing the Asoclal Index score. Since increases and decreases in the other scale scores were not consistent there seems to be no general trend in attitude change. This suggests that changes were due to Individual differenoes in the juveniles rather than due to the effect of the group home program.

Seven Male Entrance Scores. Table VIII shows the composite profile of the seven males who took the Jesness upon entrance Into the attention hoine. As shown by the profile all of the individual scales as well as the Asocial Index are within one standard deviation of the normal range. The Asoclal Index falls at the elghty-rifth percentile of the nondelinquent population. There was no significant difference in the Asoctal Index score of the population $N=4$, for whom the score was slxty-one, and the mean entrance score for these seven males which was s1xty. 


\section{TABLE VIII}

COMPOSITE JESNESS SCORES OF SEVEN MALES AT ENTRY TO NEXT DOOR, INC.

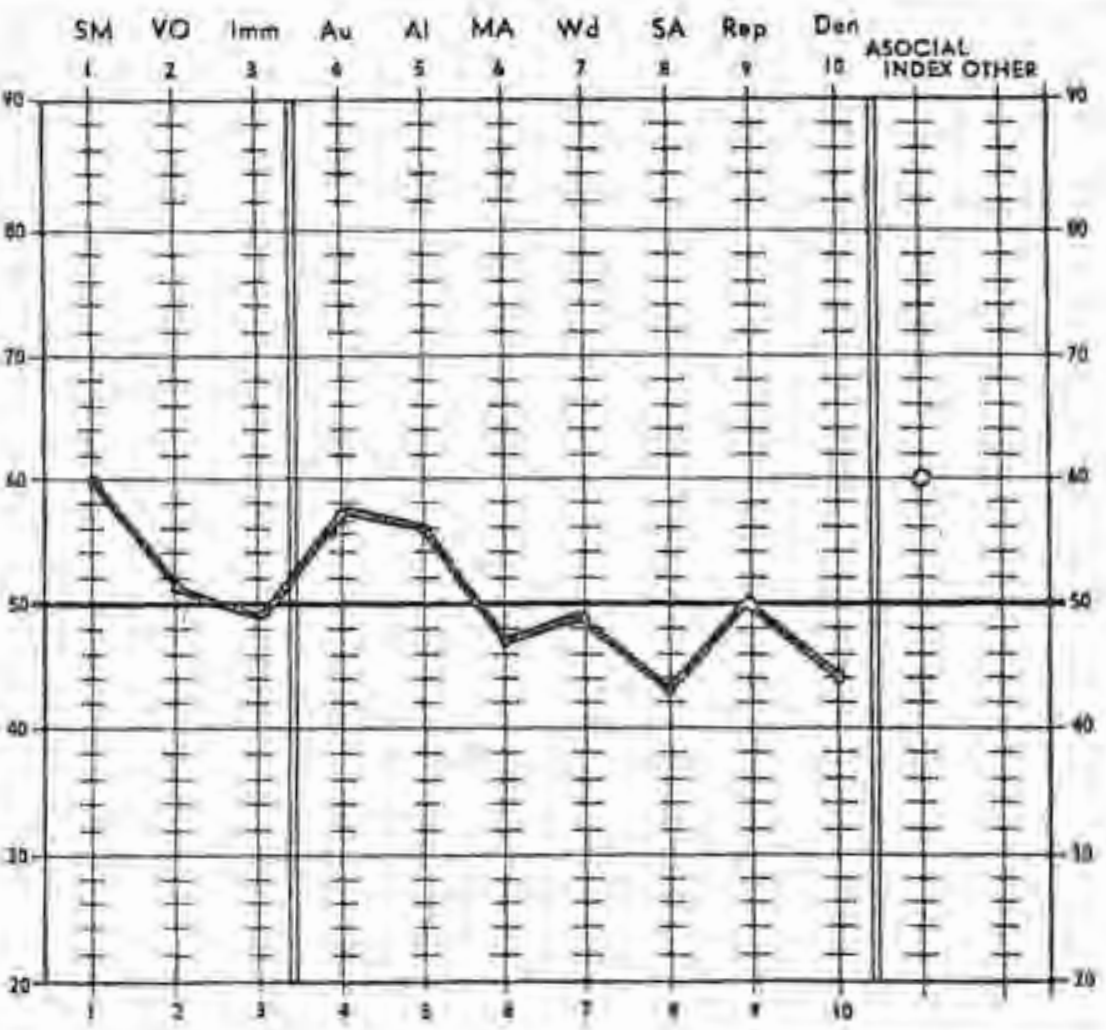

SM - SoclaI Maladjustment

Vo - Value orientation

IMM - Immaturity

AU - Aut1sm

$A L$ - Allenation

MA - Manifest Aggression

WD - W1thdrawal

SA - Social Anxlety

REP - Repression

DEN - Den1a1

AI - Asocial Index 
A two-talled test of slgniflcance was applied to the scores of the same seven males in Table VIII and to seven random males chosen from a similar group home located in Salem. Table IX presents the results.

\section{TABLB IX}

TWO-TAILED TEST OF SIGNIFICANT DIFRBRENCE FOR JESNESS ENTRANCE SCORBS FROM THE

NEXT DOOR, INC., AND MIDVALLEY ADOLESCENT TREATMENT CENTBR

$$
(\mathrm{N}=7)
$$

\begin{tabular}{|c|c|c|c|c|}
\hline SCALE & NEXT DOOR & MIDVALLBY & 5 & $\begin{array}{l}\text { S1gni- } \\
\text { rlcance }\end{array}$ \\
\hline $\begin{array}{l}\text { Soclal } \\
\text { Maladjustment }\end{array}$ & $\begin{array}{l}\bar{X}=59.57 \\
S=9.81\end{array}$ & $\begin{array}{l}\bar{X}=55.29 \\
\mathrm{~S}=12.12\end{array}$ & .727 & $7 \mathrm{NS}$ \\
\hline $\begin{array}{l}\text { Value } \\
\text { Orientation }\end{array}$ & $\begin{array}{l}X=50.71 \\
S=9.87\end{array}$ & $\begin{array}{l}X=48.86 \\
s=13.29\end{array}$ & .297 & 7 NS \\
\hline Imma turl ty & $\begin{array}{l}\bar{X}=48.85 \\
\mathrm{~S}=11.13\end{array}$ & $\begin{array}{l}\pi=46.29 \\
s=12.98\end{array}$ & .398 & 8 NS \\
\hline Aut1sm & $\begin{array}{l}\bar{X}=57.00 \\
S=10.50\end{array}$ & $\begin{array}{l}\bar{X}=50.00 \\
S=9.49\end{array}$ & 1.21 & NS \\
\hline Allenation & $\begin{array}{l}\bar{x}=55.86 \\
s=12.73\end{array}$ & $\begin{array}{l}\bar{x}=51.86 \\
s=10.49\end{array}$ & .594 & 4 NS \\
\hline $\begin{array}{l}\text { Mantfest } \\
\text { Aggression }\end{array}$ & $\begin{array}{l}\bar{X}=47.29 \\
S=8.66\end{array}$ & $\begin{array}{l}\bar{X}=46.29 \\
s=7.74\end{array}$ & .211 & 1 NS \\
\hline W1 thdrawal & $\begin{aligned} \bar{X} & =49.29 \\
S & =8.86\end{aligned}$ & $\begin{array}{l}\bar{X}=48.00 \\
S=9.96\end{array}$ & .236 & 6 NS \\
\hline $\begin{array}{l}\text { Soclal } \\
\text { Anxtety }\end{array}$ & $\begin{array}{l}\bar{X}=43.00 \\
S=\bar{B} .37\end{array}$ & $\begin{array}{l}\bar{x}=43.71 \\
s=5.95\end{array}$ & .170 & NS \\
\hline
\end{tabular}


TABLE IX--ContInued

\begin{tabular}{|c|c|c|c|c|}
\hline SCALE & NEXT DOOR & MIDVALLBY & $\mathrm{t}:$ & $\begin{array}{l}\text { S1gni- } \\
\text { I1cance }\end{array}$ \\
\hline Represston & $\begin{array}{l}\bar{x}=49.86 \\
s=11.12\end{array}$ & $\begin{array}{l}\bar{X}=46.86 \\
S=11.19\end{array}$ & .466 & NS \\
\hline Dental & $\begin{array}{l}\bar{x}=43.57 \\
s=11.89\end{array}$ & $\begin{array}{l}\bar{X}=46.86 \\
S=8.03\end{array}$ & .561 & NS \\
\hline $\begin{array}{l}\text { Asoclal } \\
\text { Index }\end{array}$ & $\begin{array}{l}X=60.00 \\
S=8.57\end{array}$ & $\begin{array}{l}x=60.57 \\
s=10.53\end{array}$ & .103 & NS \\
\hline
\end{tabular}

None of the scores between the two groups differed signiflcantiy, thus showing that these juveniles in the Next Door, Inc, have attitudes that are similar to the Salem group. In both aases the Asocial Index centered around 60.00 and all the scores fell within one standard deviation of the mean.

Table $X$ includes the first and last scores of the s1x Juveniles taking the Jesness at least tw1ce, regardless of the time span between testing. Th1s provides a rough Index, but the best aysilable at this point, of changes taking place over different time periods. For one subject scores from T1me II and T1me III were used; for another, scores from Time I and Time III were used; 
for a third, TImes IV and $V$ were used, For the remainIng three juventles Times I and II were used.

TABLE $X$

TWO-TAILED TEST OF SIGNIFICANCE FOR RELATED MEANS COMPARING FIRST AND LAST SCORES

(ASOCIAL INDEX)

$N=6$

\begin{tabular}{lcccc}
\hline & $\bar{x}_{1}$ & $\bar{x}_{2}$ & $\underline{t}$ & $\underline{p}$ \\
\hline $\begin{array}{c}\text { Asoc1al } \\
\text { Index }\end{array}$ & 62.50 & 75.00 & 3.969 & $.02^{*}$ \\
\hline
\end{tabular}

*SIgniflcant at the .01 level for a one-talled test.

Here again the Asocialization score increased from 62.50 to 75.00 at the .02 signirlcance level lndicating an 1ncrease in delinquent att1tudes. A score of 75.00 is in the ninety-ninth percentile of the nondelinquent population. The probablitty that other samples would show 1mprovement in dellnquency proneness is less than one chance in a hundred. It is probable that in ninetyelght out of a hundred samples deterloration would occur.

\section{Attitude Questionnalie}

1. Real friends are hard to flnd where I IIve. This question almed to find out if Juveniles in the group home had difrieuities in forming peer rela- 
t1onshlps, or at least percelved themselves as having trouble making frlends they could trust. If this were the case, a group home shared by peers with sim1lar problems in which opportunity and encouragement were provided for relationship bullding, should have a beneflolal effect. The mode of responses was generally positive, with six answering Very untrue or Untrue. Four felt that this was true or very true, while ane was undecided.

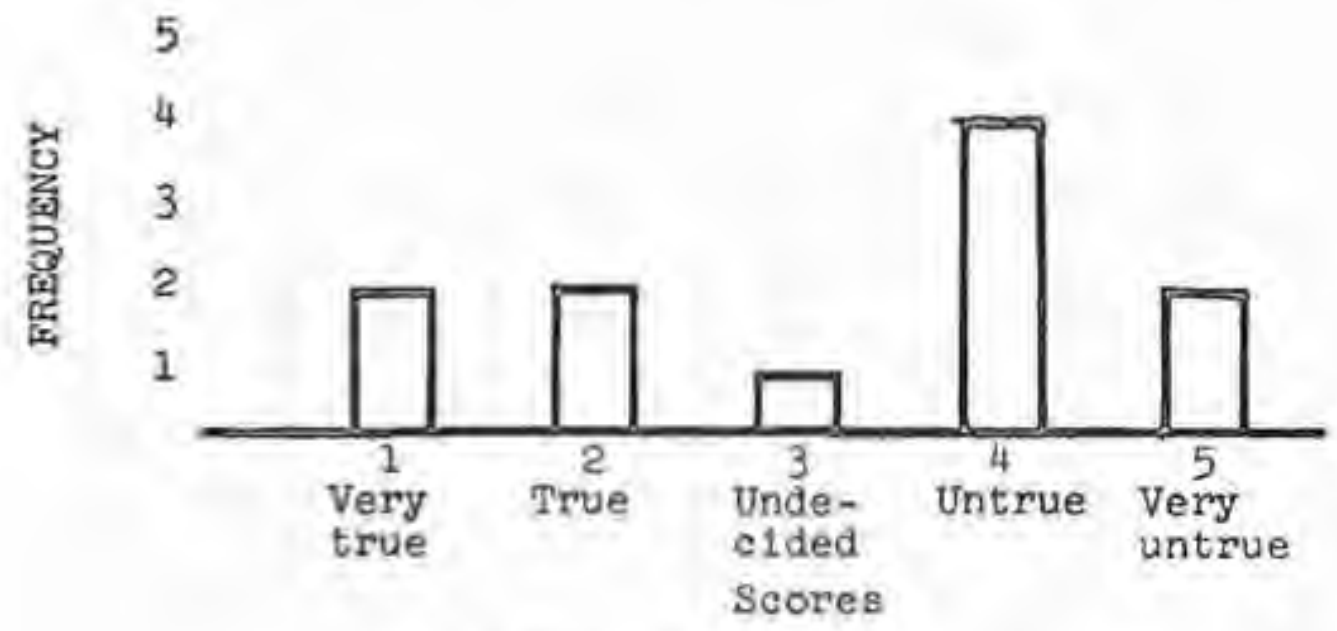

FIGURE 1

FAIENDS

2. Some people in my town "get by with murder" while others take the rap for dolng any little thing wrong.

Th1s question almed at uncovering the youth's underlying attitude towards the falmess of the commun- 
Ity and or authority figures in general. A baslcally negative sesponse such as Very true or True, may 1nd1cate that the youth's past assoclations with authority have led him to see $1 \mathrm{t}$ as unfalr, domineering and not to be trusted.

The scores ranged from one to flve, with the largest number of responses (five) undeclded. Four fuvenlles felt this was baslcally true, and two felt that 1t was untrue.

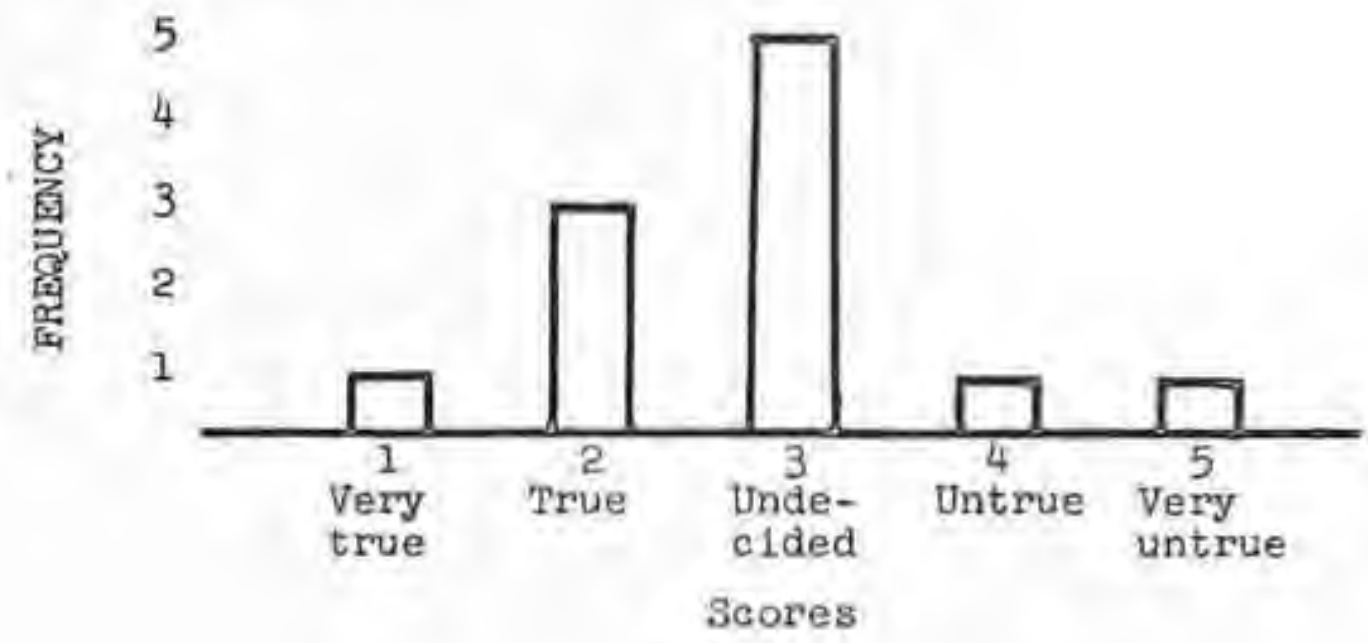

FIOURE 2

WATRNESS

3. People are not concerned about what kids do as long as they keep out of trouble.

The youthts self-concept (feelings of "nobody cares about me") and possible past negative community/ 
authorlty experiences were the focus of exploration here. Do these youths feel others are concerned about them?

The largest number (five) felt that people were concerned about them. Only one fuventle felt this statement was very true, and two that 1 t was true. Three Juvenlles were undeclded, and no one gave a Very untrue response.

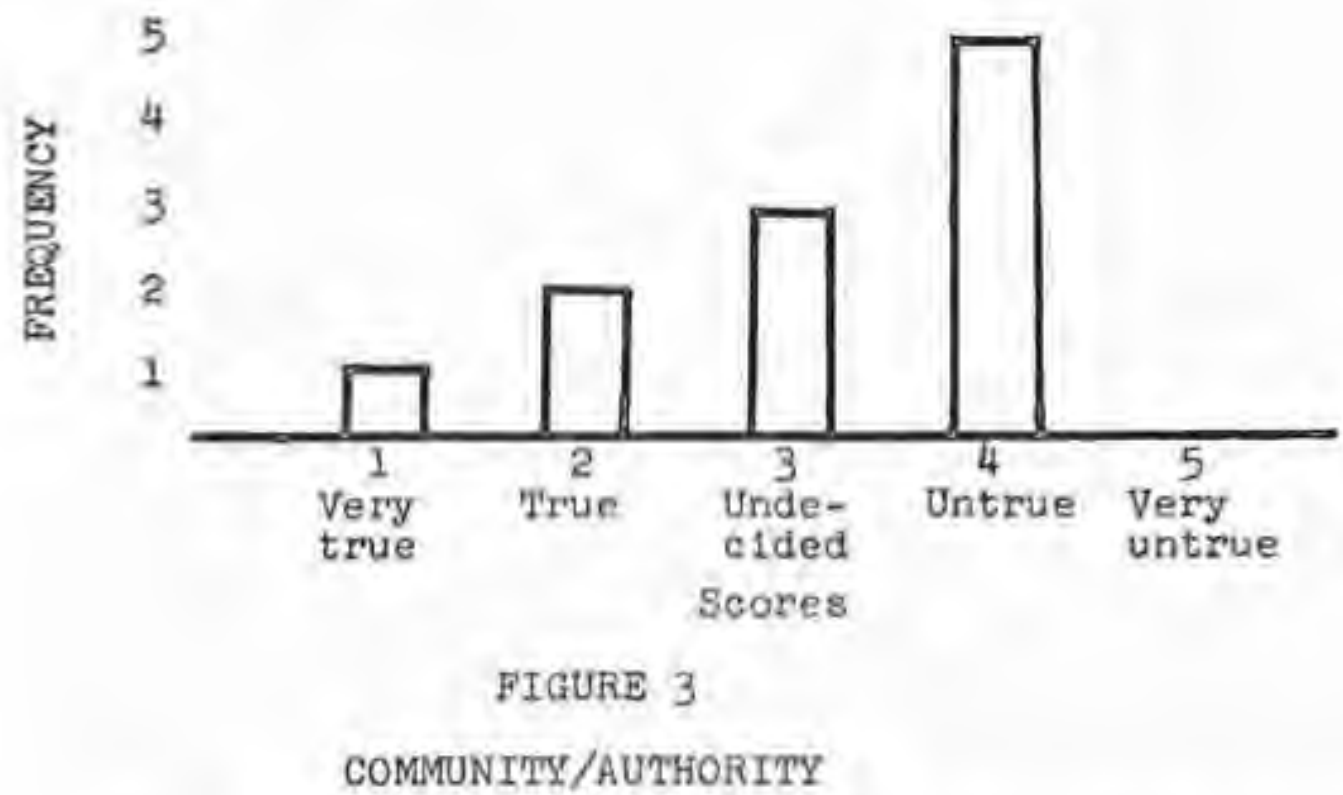

Questions 4 through 8 were rated on a seven interval continuum with one (1) the lowest posstble score and seven (7) the highest possible score.

4. How do you feel about the community's (schools, court, police, nelénbors, etc.) concern and interest for you? 
Responses were placed on a contInuum on whleh "Very ooncerned" (7) was the most positive response and "Not concerned" (1) was the most negative response.

The responses ranged from one through seven. One youth felt the community was very concerned, whereas two felt 1 t was not concerned. Responses 5 through 7 were taken as positive responses; four fell into this category. Three Juveniles gave an uncommltted response and four felt the community was not concerned.

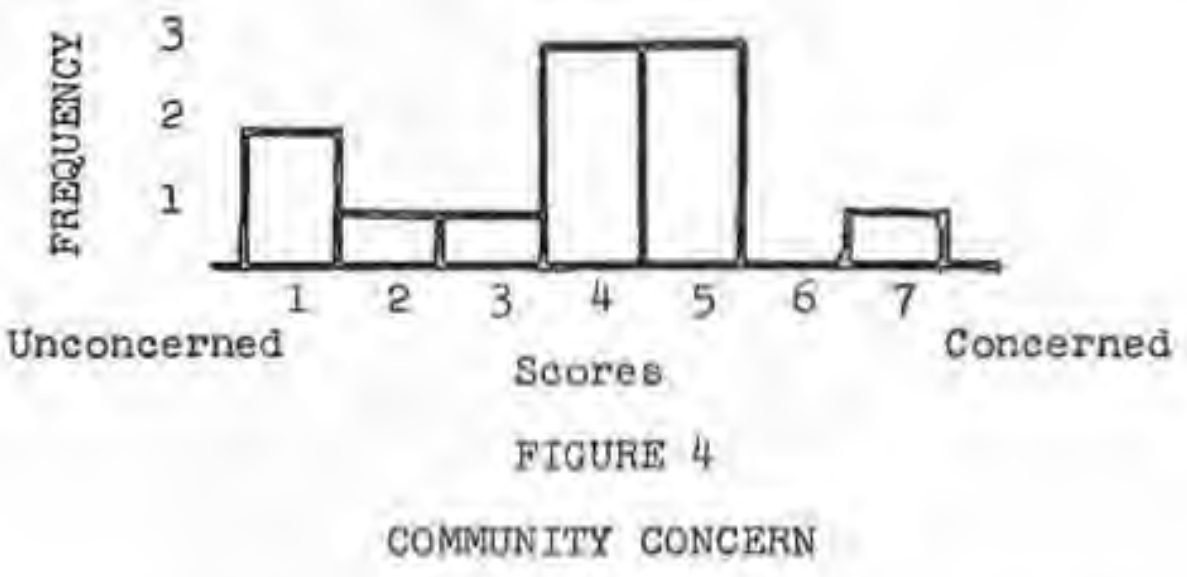

5. Have you learned anything whlle being here (about yourself, others, etc.)? 




FIGURE 5

LEARNING EXPERIENCE

*Two subjects did not respond to thls question due to changes made in the quest1onnalre.

Th1s question a1med to learn if the juveniles percelved their experience in the home as a learning or educational experience for thern. Responses to this question were the most positive of any of the questions, with three answering in the \#7 category, "A great deal." SIx youths answered positively; only one youth felt indifferent and two youths answered in the most negatlve category; "Nothing."

6. Are you happy with the way you are as a person? Response categories ranged on a continuum from Very happy (7) to Very unhappy (1). Th1 \& question was a perception check on the youth's feelings about his self-concept or satisfaction with his self-inage. 


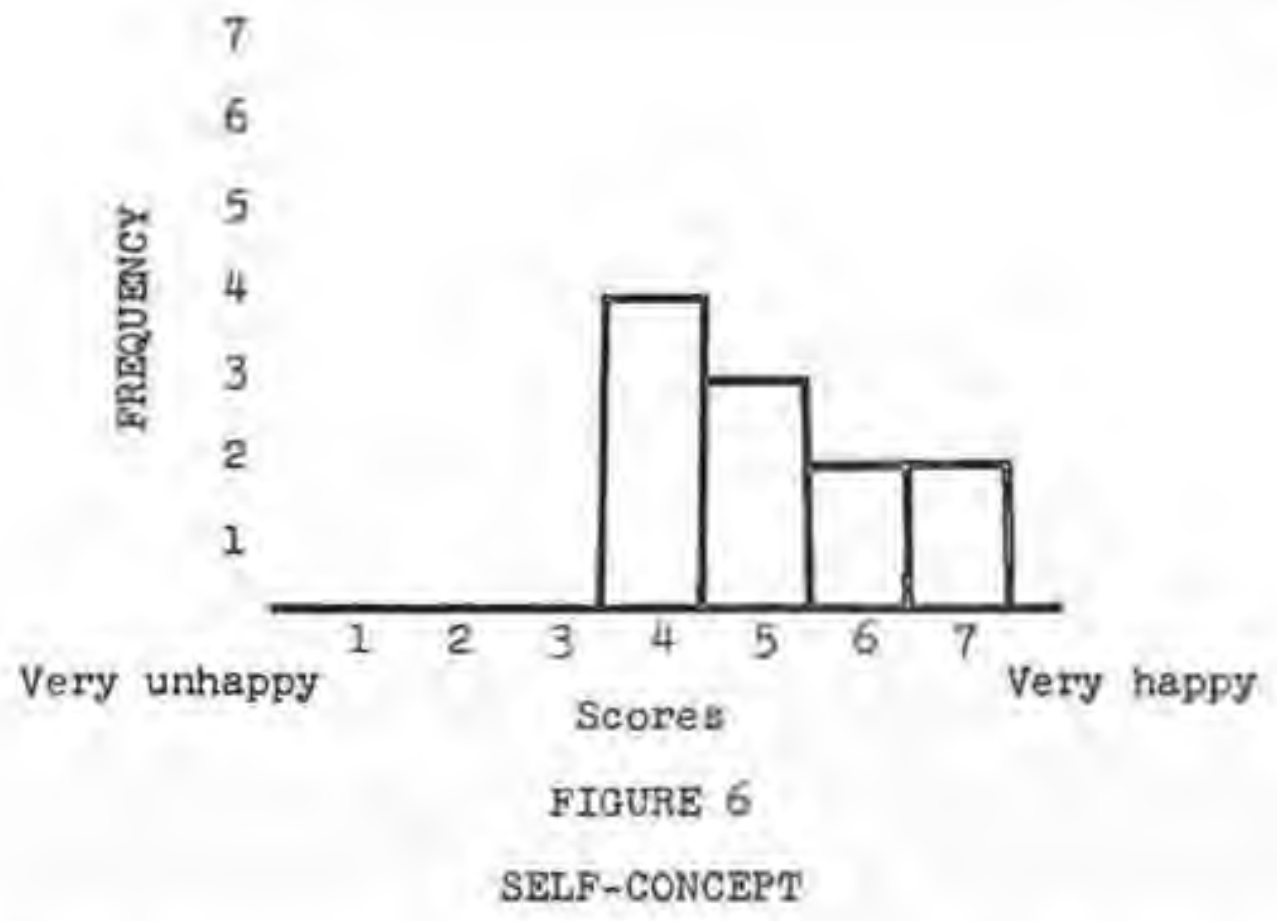

No one answered in the negative category, whereas four youths were amblvalent in their response. Seven youths answered that they were happy or very happy w1th themselves. In comparing 1ndividual scores from question 6 to question 5 , 1t was shown that those who sa1d they had learned very much in the group home program also felt very happy about themselves. In most cases the scores matched eyenly. In the two cases in which subjects reported they had learned "nothing" while at the Home, they rated the $1 \mathrm{r}$ happlness about themselves as a person at 4 , the middle category. 
7. Are the houseparents reasonable in their expectations and rules for you?

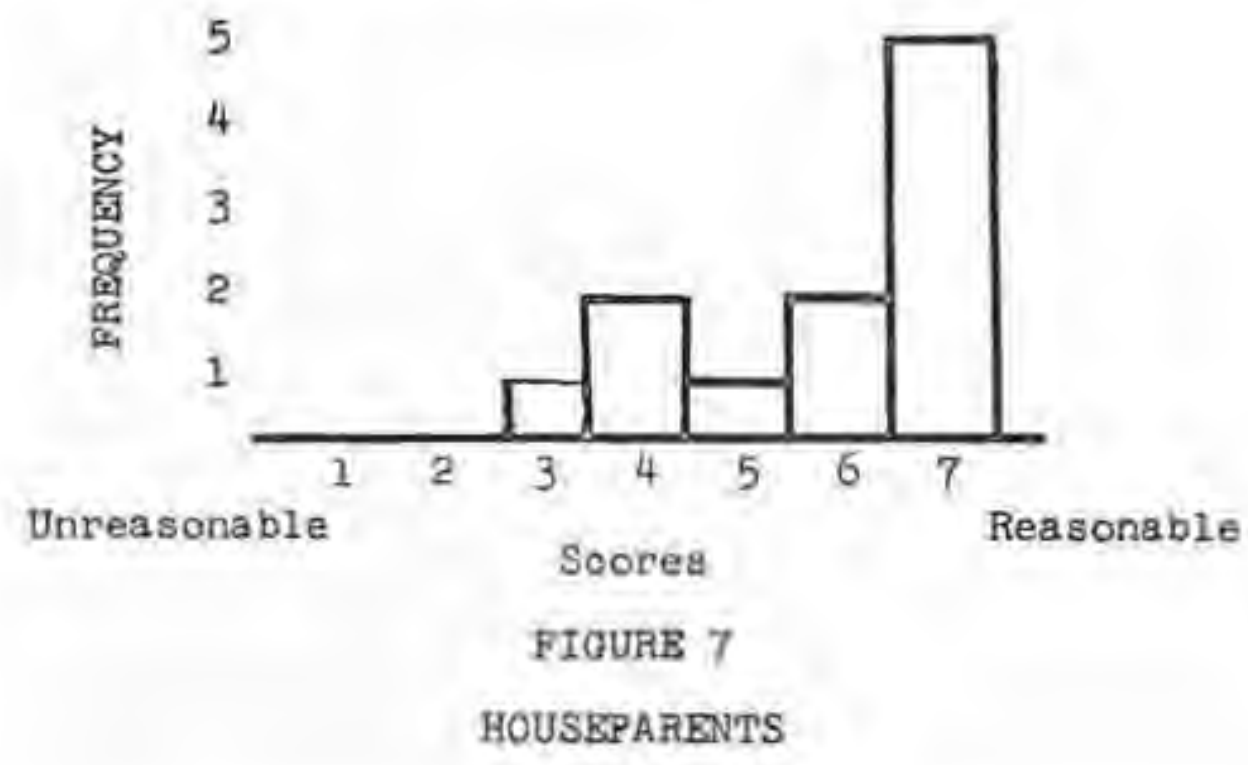

The responses were heavily skewed in a positive direction and no one was very dissatisfled with the houseparents' expectations and rules. All but three respondents answered favorable, with five indicating that rules and expectations were very reasonable. None thought these were very unreasonable (\#1 or \#2 response); only one youth felt they were somewhat unreasonable (\#3 response).

8. How well do you reel you get along with most or the klds here?

Here again quality of peex relatlonships and the child's sense of belonging to the group was the focus of exploration. 


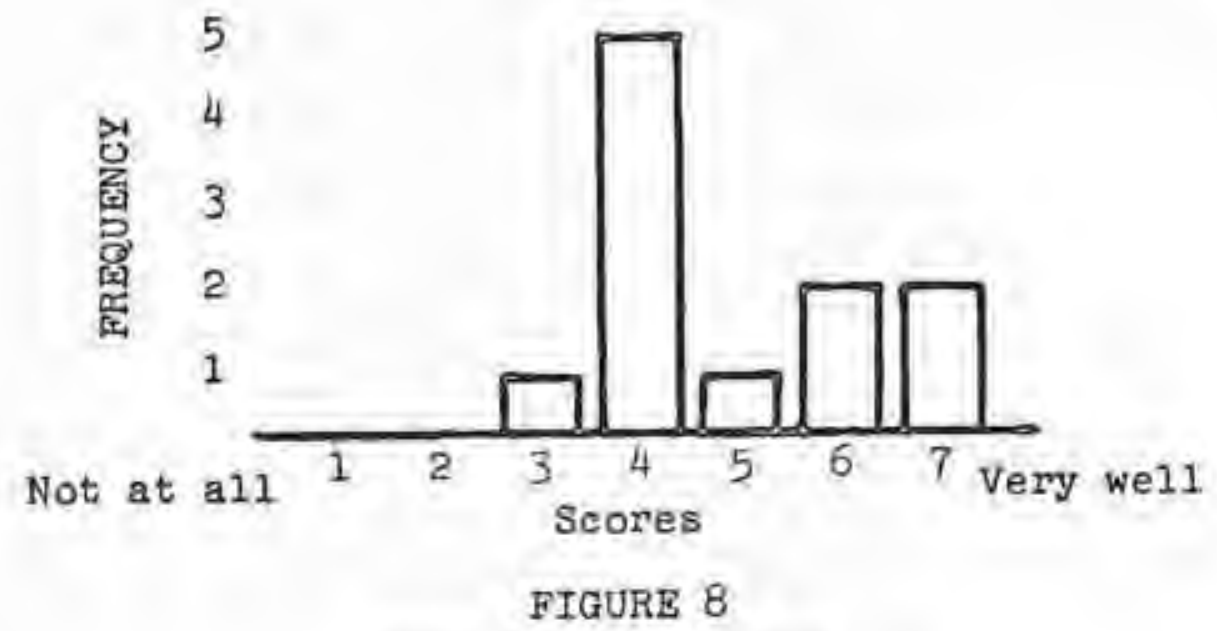

PEER RELATIONSHIPS

Five youths felt that they got along well with their peers at the attention home, whereas one youth felt he did not. Five youths felt that they got along w1th their peers nelther very well nor very badly.

These scores tended to be higher and in a more positive direction than the scores from question 1 , Indicating that the youths got along with their peers in the Home better than they did in the community. A case by case analysis of responses to the two questione supports this finding in all but two cases. The dilference may reflect the influence of the attention home in providing a feeling of belonging to a group.

\section{The Semantic Differential}

This test 18 a means of objectifying the subJects' reactions to words as symbols of their relation- 
shlps to authority, to themselves and to thelr experlence in the Home. Raw scores were converted to an 1ndex representing the proportion of maximum scores possible for an individual. The posalble range is from .00 to 1.00 , on various indices. The evaluative Index refers to the subject's evaluation of his relat1onship: the potency index gets at the influence of a relationship on the subject. The activity index $1 \mathrm{~s}$ a way of getting at the subject's modal behavior-Whether typically passive or active, as this might influence the other indices.

Table XI shows the relationsh1p of scores on the Indices, ranked separately from hlghest to lowest.

\section{TABLE XI}

SEMANTIC DIFFBRENTIAL SCALE SCORES FOR THE NEXT DOOR, INC,

\begin{tabular}{|c|c|c|}
\hline Bvaluat1ve & Potency & Act $1 v 1$ ty \\
\hline $\begin{array}{l}.857 \\
.821 \\
.809 \\
.785 \\
.785 \\
.785 \\
.714 \\
.524 \\
.500 \\
.476 \\
.285\end{array}$ & $\begin{array}{r}1.000 \\
.834 \\
.809 \\
.778 \\
.761 \\
.761 \\
.657 \\
.619 \\
.619 \\
.429 \\
.429\end{array}$ & $\begin{array}{l}.851 \\
.761 \\
.761 \\
.761 \\
.722 \\
.714 \\
.714 \\
.667 \\
.619 \\
.571 \\
.571\end{array}$ \\
\hline
\end{tabular}


The range was from .285 to 1.00 , with means centered around .70 . Taking .50 as a middle score, only two of those taking the test evaluated the Home or reacted to authority below this standara. No one tended to be on the passive side of reactive behavior. Attitudes to the Home and to authority tended to be well on the positive side, but not "enthusiastic."

Table XIT presents the scored ratings on the concept "Author1by." Scores range from .285 to .928, w1th a mean centering about .60 .

TABLE XII

SEMANTIC DIFFERENTIAL SCALE SCORES FOR AUTHORITY

\begin{tabular}{|c|c|c|}
\hline Evaluative & Potency & Activity \\
\hline $\begin{array}{r}.928 \\
.821 \\
.786 \\
.714 \\
.690 \\
.678 \\
.607 \\
.517 \\
.500 \\
.285 \\
.285\end{array}$ & $\begin{array}{l}.904 \\
.761 \\
.761 \\
.722 \\
.714 \\
.667 \\
.524 \\
.517 \\
.429 \\
.429 \\
.285\end{array}$ & $\begin{array}{l}.809 \\
.761 \\
.761 \\
.714 \\
.666 \\
.611 \\
.524 \\
.517 \\
.500 \\
.476 \\
.285\end{array}$ \\
\hline $\begin{aligned} \varepsilon X & =6.812 \\
\bar{X} & =.619\end{aligned}$ & $\begin{aligned} \Sigma x & =6.712 \\
\bar{x} & =.610\end{aligned}$ & $\begin{aligned} \Sigma x & =6.623 \\
\bar{x} & =.602\end{aligned}$ \\
\hline
\end{tabular}


The results of this test are in keeping with other material in these areas, and together possibly reflect that the adolescents react to their present situation in the Home more positively than one might expect from their underlying predispositions.

TABLB XIII

SEMANTIC DIFBERENTIAL SCALE SCORES FOR SBLF-CONCEPT

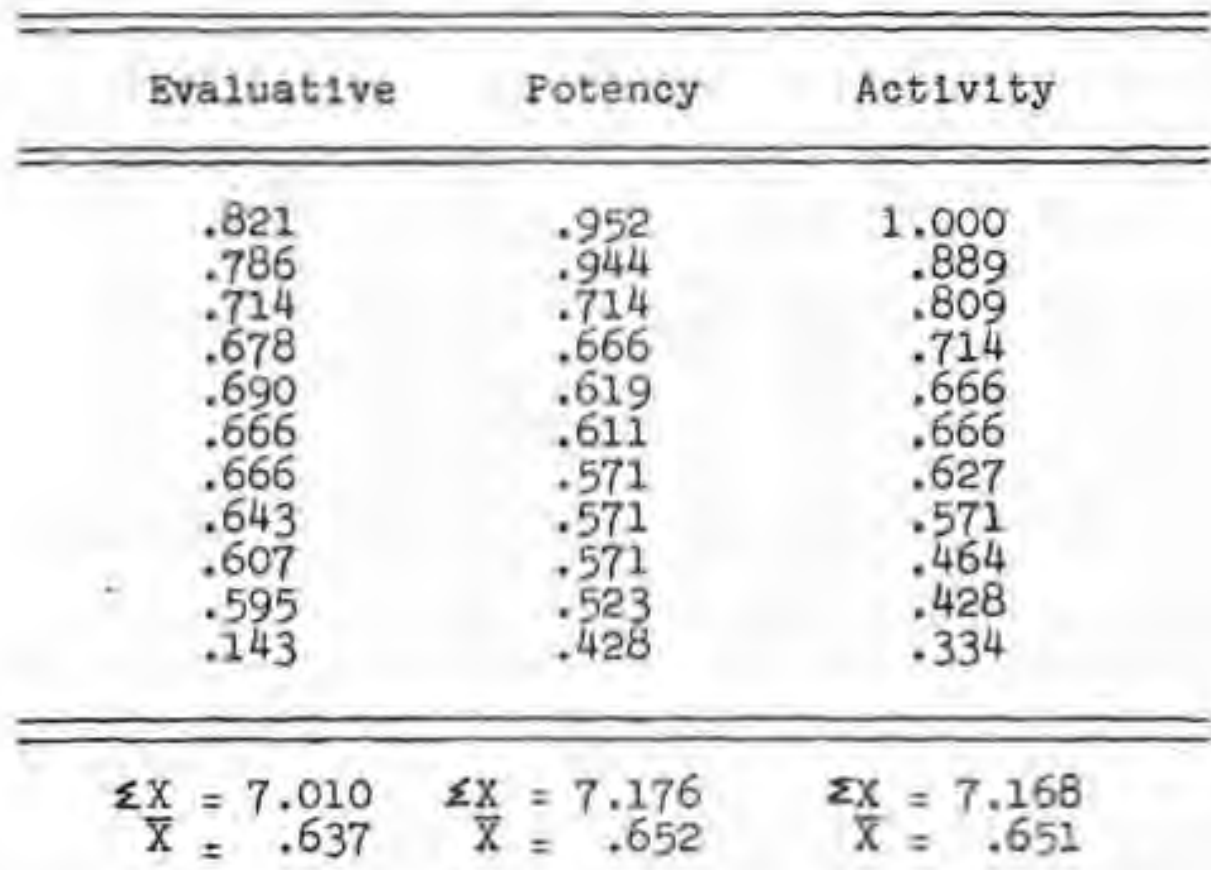

The range of scores for this scale was. . 43 to 1.00. The means centered around .65 . Most subfects' evaluations of their self-concept were above the thidale score of .50 , Indicating that they valued themgelves more than felt they were somewhat useless of worthless. The majority also felt themselves to be 
potent or Inrluential, as well as generally active Individuals, With a few exceptions, then, these Juveniles appear to possess sverage and basicaliy healthy self-concepts.

TABLE XIV

RAW SCORES CONVERTED INTO RANK SCORES ON SEMANTIC DIFFERENTIAL SCALE

\begin{tabular}{|c|c|c|c|c|c|c|}
\hline \multirow[b]{2}{*}{$\begin{array}{l}\text { JUVB- } \\
\text { NILB }\end{array}$} & \multicolumn{2}{|c|}{ NEXT DOOR } & \multicolumn{2}{|c|}{ AUTHORITY } & \multicolumn{2}{|c|}{ SELF } \\
\hline & $\begin{array}{l}\text { Bvalu- } \\
\text { ative }\end{array}$ & $\begin{array}{l}\text { Po- } \\
\text { tency }\end{array}$ & $\begin{array}{l}\text { Evalu- } \\
\text { ative }\end{array}$ & $\begin{array}{l}\text { Po- } \\
\text { tency }\end{array}$ & $\begin{array}{l}\text { Evalu- } \\
\text { at1ve }\end{array}$ & $\begin{array}{l}\text { Po- } \\
\text { tency }\end{array}$ \\
\hline $\begin{array}{l}A \\
B \\
C \\
D \\
B \\
B \\
G \\
B \\
I \\
J \\
K\end{array}$ & $\begin{array}{c}10 \\
3 \\
7 \\
1 \\
9 \\
2 \\
5 \cdot 5 \\
5 \cdot 5 \\
4 \\
11 \\
8\end{array}$ & $\begin{array}{c}11 \\
5.5 \\
8.5 \\
1 \\
8.5 \\
5.5 \\
3 \\
2 \\
4 \\
10 \\
7\end{array}$ & $\begin{array}{r}11 \\
\frac{1}{8} \\
6 \\
2 \\
7 \\
4 \\
3 \\
5 \\
10 \\
8\end{array}$ & $\begin{array}{c}11 \\
5 \\
7 \\
1 \\
10 \\
2.5 \\
2.5 \\
4 \\
6 \\
9 \\
8\end{array}$ & $\begin{array}{r}10 \\
4 \\
7 \\
1 \\
9 \\
5 \\
3 \\
2 \\
6 \\
11 \\
9\end{array}$ & $\begin{array}{l}11 \\
10 \\
6 \\
1.5 \\
4 \\
1.5 \\
5 \\
3 \\
7 \\
8 \\
9\end{array}$ \\
\hline
\end{tabular}

The scores for each individual on the evaluative and potenoy factors on all three concepts were ranked In order to determine if there were any correlations between scores on any two concepts, The rank correlatlon between the Next Door, Inc, and Authority on the potenoy factor is .89, a signiflcant and very high oorrelation. This indicates a high association between 
the way the fuveniles percelve the potency (Influence and powerfuIness) of the Next Door, Inc., and their underlying attitude towards authorlty. Thus we can assume that if a child enters the Home with a hostile attitude towards authority, this will affect his perception of the Home.

A raik correlation was also run between the Next Door, Inc, and Self-concept on the potency factor. A correlation of .64 was found, showing only a moderate relationship. Thus, the Juvenile's perception af his own ability to be effective and influential with others has a bigniffcant but not very close relationship to his perception of the effectiveness and influence of the Next Door, Inc.

In comparing the potency faotor scores of each Individual to his scores on question 5, "Have you learned anything while being here?" 1 t was found that those who felt the flome was very influentlal in their lives also felt they had learned a great deal, and vice versa.

\section{Subject1ve Interview Responses}

The researchers asked each juvenile interviewed why he belleved he was placed in the Home and to explain what kind or kids the Next Door, Inc. was designed for. They were also asked now outsiders viewed the Next Door, Inc. With these quest1ons the researchers hoped 
to disoover whether these Juveniles and the surrounding community viewed them as delinquents and to see if they viewed placement in the Home as punlshment or as a way to recelve help.

A11 of the interviewees sa1d the Home was designed for kids with family problems and none mentioned explicitiy it was for delinquents. Two comments follow, one from a male and one from a female, which are representat1ve of answers to the question concerning the types of kids placed in the Home.

It's more for kids with fam1ly problems rather than for delinquents.

Three are here because things are messed up at home. One has personal problems. one was booted out of every school and one is here for runaway. It's set up for people with personal problems but not enough to be in McClaren.

There were a varlety of answers to the question of how others outside the Home see the Next Door, Inc.

K1ds on the cuts see $1 \mathrm{t}$ as a temporary place to stay.

The neighborhood really doesn't know about the Home. I have frlends around the town and they all think this is a really nice place.

The kids think $1 t^{\prime}$ 's a far out place, most parents like it too but one said It was a place for hoodlums and he wouldn't let his daughter go out with me. 
Kids in the community wish they were

here because we have more freedom.

Some parents complain because they

feel we have too much freedom.

Another series of questions were almed at uncov-

ering the Juvenlles feelings about how they are

treated at the Next Door, Inc. All reelings given were positive, except in one instance, and the word "faif"

came up time and time again.

There is no basis to complain, everything is falr and everyone is treated the same.

D1ck and Holly (houseparents) are more like parents than my real ones.

Dick is good at helping with personal problems, he gets at you in a round about way.

People here are nice to be with and they don't put you down.

One boy felt more negative than the others and he said, "the houseparents only talk to you when you're in trouble." It is of 1nterest that his responses to the attitude questionnalre were also generally negative.

When asked what the juveniles would change if they were running the home, they had trouble thinking of a response. Most of them sald they wouldn't change anything but when pressed, some added they might change some of the rules such as having to stay home three nlghts a week, having to eat meals every night during the week, and chang1ng the curfew. 
I wouldn't change anything. Dick and Holly make mistakes but they apologize afterwards. We can spend nights with frlends, it's no different here really, all parents make you come $1 \mathrm{n}$.

In another question the researchers asked what the fuventles had learned from being in the Home and if they would recommend the Next Door, Inc, to a frlend if their frlend needed help. The responses are so varled that each Juvenile ${ }^{t} \mathrm{~s}$ answers are given below.

1. I'm getting what I want, there's a good school here so I'm satisfled.

It depends on the situation as to whether or not I'd send a f'riend. I would if they needed a sohool or are having home problems.

2. People are helpful, everyone tells each other problems and tries to help one another. I didn't have any problems so didn't need to be helped.

It teaches you how to get along with people different from you.

3. You learn to know people better here than you do in other places.

4. Klds get all the help they need. Some resent discipline but they need $1 t$.

I can work out problems alone but I have learned to handle respons1b111ty better and to create in harmony with others. Before I would punch someone in the mouth rather than try to settie it by talking.

5. It helped with everything, my temper is better, I'm a better dresser now. 
6. It's no help except I don't have to see my stepiather. I didn't learn anything.

7. I'm learning to work things out with others by talking.

8. I learned how I act and I act differently in Hood River. I've been taking less drugs because I don't get any k1cks from them anymore.

There were no questions on the group meetings speclfically although some of the Juvenlles commented an them:

Group meetings aren't so good because no one wants to open up. I don't like to talk about problems in group because all the kids aren't the type you'd discuss things with.

I don't feel they are so good because we're forced to go to them. The $\mathrm{klds}$ close up and get derensive. I took psychology in school so I'm used to things like this. The others aren't and they don't trust each other yet.

For those juveniles who had been in foster homes previous to going to the Next Door, Inc, the researchers asked whlch they 11ked the best and why. They all sa1d they would rather be in the Next Door, Inc.

I left the foster home because I was always having to babysit. I want to live at home but mother has to settle down.

Th1s $1 \mathrm{~s}$ better than a foster home because foster parents are oldeg and there is less contact.

You're a slave in a foster home. 
Th1s chapter presented the findings on the main verlables of this study as measured by the four instruments of data collection. The next chapter presents suggested Implications of this data and recommendations for the program of the Next Door, Ine. 


\section{CHAPTER V}

\section{SUMMARY AND IMPLICATIONS}

1. The findings of the Jesness Inventory 1ndicate that seventy-three per cent of the Juveniles who partic1pated in the research recelved an Asoctal Index score of 60.00 or higher, thus Indicating that they possess attitudes somewhat more delinquent prone than the average nondelinquent Juvenile. Although these Juveniles are within the normal range for the1r age, they are more delinquent prone than reasons ior the1r referral might suggest. They alsa have more serlous soclal and psychologlcal problems than appear on the surface.

However, their attitudes have not influenced their behavior to the extent that they have committed serious yiolations of the law, thus diversion from the fudicial process and from conflnement in a county jall seems an appropriate goal whlch the Home is a means of achleving. This approach avolds the negative effects of Isolation from the community agencles, As an alternative to detention in the county Jall, and as a neutral home for youth in times or ramily crises, the Home has potential as a valuable and viable resource for the community, and, cur study shows, for the juventie, 
2. AII Juveniles in the TIme I and II comparisons held signiflcantly more delinquent attitudes arter a stay in the Home of two months. Asoclal Index scores at Time II averaged at 71.00 , two standard deviations above the norm for the nondelinquent population. The research did not uncover the reasons for this. In vlew of the positive reactions to the Home, the factors probably do not lie with any part of the program or relationshlps, except insofar as effort to discover the reasons for this increase and to treat them have been missing. Further research is necessary to determine if this trend w11l continue. The research team recommends that the Jesness Inventory continue to be given to all youths at entry to the Home and again at some speoifled t1me period.

3. If the trend towards an Increase in the Asoclal Index is found to continue, this indicates that the Juveniles' attitudes are changing towards those of a delinquent subculture. Although further research is needed to determine the factors contributing to the youths' regression with respect to delinquency proneness and soclal adjustment, the researchers found that In all cases in which the Asocial Index increased, the Social Maladjustment score also increased considerably. The Soclal Maladjustment score, which refers to 


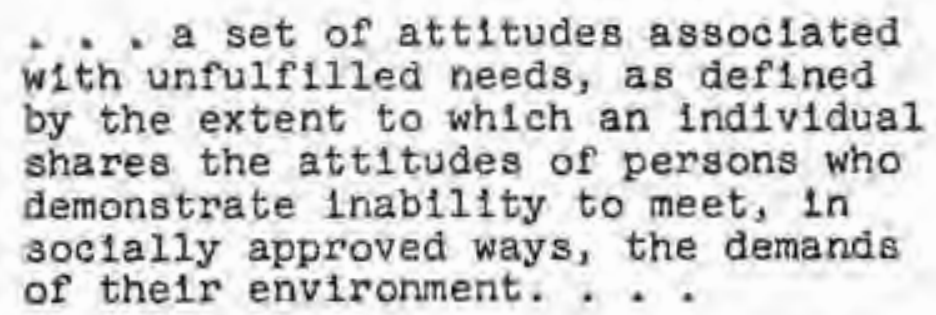

is double-we1ghted in tabulation and has a sizabie influence on the direction of change in the Asoctal Index score. An implication of this finding is that these juveniles need help in developing values among themselves that are nondelinquent. Th1s can be done by means of a closer peer/staff relationsh1p and by a therapeutic milieu in whioh positive, nondelinquent values and attitudes are highly respected and modeled. Another means to achleve this end is through group meetings and activities in which a "group consclence" Is encouraged to develop.

4. While continuing study is indicated, the data we have is consistent, has known statistical signiflcance and can be used as a firm but tentative basis of program development and Individual treatment. Mean scores for each scale of the Jesness can form a basis for developing the direction of programs. Standard deviatlons indicate how much flexibility in a program is indicated. In most cases, the higher the standard deviation, the more individual differences should be 
considered. Scale scores indicate how much attention or emphasis is warranted with respect to a given factor. High scores for all scales, except that of the scale Denlal, indicate that special attention is needed In that area. The probabilities, the $t$ ratios and the statistical significance at given levels indicate how closely two elements are related, and are tests of assumptions about the program.

5. The range of adjustments as shown by the standard deviations, on the Jesness scales, Is so wide that the program must be pitched to individual needs as well as to the common level of the group, and subgroups.

6. To ald in the task of evaluation of the Juventle's needs, the researchers suggest that the Jesness Inventory be used for diagnostic and program purposes. The Jesness Inventory 1 a a sound instrument for diagnosis and program control. It correlates well with the other Instruments used, and has the addea advantage of standardization and comparablitty with studies elsewhere. If not employed in this way its categorles and those of the Attitude Questionnalre and the Sernantic Different1al would be helpful guides in interviewing. These can ald in Identifying areas of confilet for the child, as well as his strong and weak polnts, which could 
Increase the houseparents' and court personnel's understanding of the child's dirficulties and needs.

7. The flndings of the Attitude Questionnalre suggest that the largest number of juveniles reel most positive about the Home 1toelf and generally positive or in the middle range about thelr relationshlps w1th their peers and about themselves. Th1s 1ndicates that these juveniles generally have close peer relationships and are very 11kely to be influenced strongly by thelr peers in their attitudes and values. Attitudes toward community and authority were more negative than positive, suggestIng that these youths' perceptions of authority flgures may be influenced by past negative, hostile or unfair experiences, whether w1th parents or other authority rigures. Scores on the Allenation Scale of the Jesness, 1.5 standard devlations above the norm mean on the average, conflrm this finding. This does not tell us if the youth's perceptions of his experlences with authority are real1ty-based or due to a psychologlcal predisposition within the 1ndividual. In elther case, It may be a factor on which the treatment program could focus elther through groug discussions on feelings and att1tudes toward author1ty, 1.e., rules, pollce, parents; or in individual counselilng sessions. 
8. From interviews with the youth, the researchers learned that they see the Hoine as a good learning experience, falr, reasonable and carling. Relations with houseparents are good, satisfylng, helpful, and seal.

9. According to the youth, the Home is well accepted by thelr peers, but not woll uriderstood or krown ty the adult commurity.

10. Many youth expressed diseatisfaction with the group meet1ngs, Group seesions calling upon them to reveal themsclves or their proolems should be used with care. Many are threatened by an in-depth treatment orlented group and care should be taken in selecting such a group and post-releage consequences need to be considered. A group in which problems of everyday I1ving are alred and discussed can be helpful to the youth and a useful tool in a residentlal setting.

11. In collecting oackrround data on these youth, it became obvious that a great many came from homes in which adequate care was not available to the juveniles. Ten of the eleven juveniles interviewed came from troken homes and hine juveniles had been placed in a loster home. In such cases a stable family 11 fe experlence 
and provision of a healthy marriage model can prove to be the most effective correction for these deflclenc1es. The structure of the group home is such that these experiences are naturally provided.

12. The da1ly contact and shared experiences between youth and houseparents give the houseparents a more Intimate knowledge and awareness or the child's needs. However, the potential seriousness and variety of problems of the juveniles warrant a well qualifled staff and treatment, not just service orientation.

13. Since adrissions seemed to be restricted by the eapacity of the Home, expansion of the program might be considered. An additional program designed as an alternative to foster care might be used in seleoted c1rcurnstances, such as when a juvenile is not ready for placement with a foster family or when his family circumstances are such that 1 is is best that he not return home, Such an alternat1ve would be especlally appropriate in view of the present lack of foster homes in Hood River.

14. Base line data indicates that two rather distinet functions of the Home should be recognized: overnight shelter, and residential shelter. It is not clear from the study what differentiations are indicated, on how 
much one interferes with the other. The researchers feel that at this point it would only be speculation to enumerate posslble factors. 


\section{BIBLIOGRAPHY}

Alan, et, al., Use of the Depth Interview In Examining Attitudes of DeIInquent Boys: An Exploratory Study, unpublished thesis, School of Soclal Work, Portland State University, Portland, Oregon 1964.

Application for Action Grant, State Law Enforcement: Planning Agency, Project Title: The Next Door, Ine.

Barron, Milton L., The Juvenlie in Del1nquent Soc1ety, Alfred A. Knopf, New York, 1955.

Carter, Robert M., "The 'Author1ty Problem' Rev1s1ted," Federal Probation, Vol. 25, (Dec., 1961), pp. 5256.

Cavar, Ruth, Juvenile Delinquency, J. B. Iippincott Co., New York, 1969.

, Readings in Juvenile Deltnquency, J. B. Ilppincott Co.2 New York, 1964.

Child Welfare League of Amerlca Standards for Services of Child Welfare Institutions, Chlld Welfare League of America, New York, 1963.

Cohen, Albert and James Short, "Research In Delinquent Subculture," Journal of Social Issues, Vol, 14 , No. 3, 1958 .

"Comunity Based Correctional Programs," Crime and Delinquency Tople Serles, National Institute of Mental Health, Maryland, 1971.

"Diversion from the Criminal Justice System," Crime and Delinquenoy Toplc Series, National Institute of Mental Health, Maryland, 1971.

Brlckson, Erik H., "Ident1ty and the Ilfe Cycle," Psychologlcal Issues, Vol. $i$, No. I, International Unlversity Press, New York, 1959. 
Falsberg, Martin, "Setting Limits with the Juvenile Delinquent," Soclal Casework, Vol, 38, No. 3 (March, 1957), pp. 138-142.

Fink, Arthur E., "Authority in the Correotlonal Process," Federal Probation, Vol. 25 (Sept., 1961), pp. $34-40$.

Glueck, Sheldon and Eleanor, Famlly Envlronment and Delinquency, Houghton-Mifflin Co., Boston, 1952.

G1bbons, Don C., and Duane C. Lemley, Correctional Feasibility Study, District 9, State of oregon Corrections Division, Salem, Oregon (June, 1971).

Hardman, Dale G., "The Constructive Use of Authority," Crime and Delinquency, Vol. VI (July, 1960), pp. $245-254$.

Institutlons Serving Delinquent Children: Guldes and Goals, V. S. Department of Health, Education and Welfare, U. S. Government Printing office, Washington, D, C.

Jesness, Carl E., The Jesness Inventory, Research Report No. 35, California Youth Authority (Nov., 1963).

Kahn, Alfred J., When Chlldren Must be Comm1tted: Proposals for Diversifled Systems of Fac1lities, Citizens' Cormitiee for Children of New York, Inc., New York (June, 1950).

Keller, Ollver J. and Benedict S. Alper, Halfway Houses: Community-Centered Corrections and TDeatment, Heath Lexington Books, Lexington, Mass,, 1970.

Kenney, John P., Pollce Work with Juvenlles, Charlea C. Thomas, Springfield, IIl, 1954.

Konopka, Gisela, Group Work in the Institution, Assoclated Press, New York, 1954. " "Our outcast Youth," Social Work, Vol. 15, Wo. 4, (oct., 1970), pp. 76-日a. 
Kvaraceus, W1lllam C., Juvenile Delinquency, Nat1onal Education Association, Washington, D.C., 1958.

Maler, Henry, Group Work as a Part of Res1dent1al Treatment, National Assoclation of Soclal Work. New York, 1965.

Moore, Bernlce M., Juvenile Dellnquency: Research, Theory and Comment, Assoclation for Superviston and Curriculum Development, Washington, D.C., 1958.

Muus, Rolf E., Theories of Adolescence, Random House, New York, 1968 .

Polsky, Howard W., Cottage SLx: The Soclal System of Delinquent Boys 1n Residential Treatment, Russel1 Sage Foundation, New York, 1962.

Reckiess, Walter, et.al., "Study of Self-Concept as an Insulator Against Delinquency "American Soc10logloal Review, Vol. 21, No. 6 (Dec., 19j6), Pp. $744-746$.

Red1, Fritz, and Dav1d Wineman, The Aggressive Child, The Free Press of Glencoe, Inc., New York, 1957.

Sher1f, Muzafer and Carolyn W., Reference Groups; Exploration Into Conformity and Deviation of Adolescents, Harper and Row, New York, 1964.

Sheridan, W1111am, "Juveniles Who Commit Noncriminal Acts: Why Treat in a Correctional System?" Federal Probation, Vol. 31, No. 1 (Maroh, 1967), pp, 26-30.

Sorenson, Roy, "Youth's Need for Challenge and a Place in Soclety," Ch1ldren, Vol. 9, No. 4 (July-August, 1962 , pp. $131-13 \mathrm{~d}$.

Standards for Child-Caring Institutions in Orezon, State Public Welfare Commission, Salem, Oregon, 1963.

Stuat, Elllot, "An outiline for Study of Social Auchority Factors in Casework," Soclal Casework, Vol. 35 (Jure, 1954), pp. 231-238. 
Selected Empirloal B1bIlography

Chandler, Charles and Albert J. Shafter, "A Critlque of the Group Placement Concept," Amerlcan Journal of Mental Deticiency, Vol. 59 (January, 1925).

Empey, Lakar T. and Jerome Labow, "The Provo Exper1ment in Delinquency Rehabilitation," American Soclologlcal Rev1ew, Vol. 26 (october, 1961).

, and Steven G. Lubeck, The S1lverlake Experlment: Deliquency Theory and Commun1ty Intervention, Aldine Publishing Co., Chloago, Ill., 1971.

Flackett, John and GaII Flackett, "Crlswell House: An Alternat 1ve to Inst Itutional Committment fov the Juvenlle of fender," Federal Probation, Vol. 34 , No. 4 (December, 1970 ).

Gula, Martin, "Group Homes: New and Dirferentiated Tools in Ch11d Welfare, Delinquency and Mental Health," Group Homes in Perspective, Chlld Welfare League of Amerlca, New York, 1967.

Halre, Sharlene and Ted Palmer, An Overvlew or Issues Central to the Use of Group Homes for Youthful offenders, State of Callfornia Human Relations Agency, Dept. of the Youth Authority (November, 1969).

MoNe11, Frances, "A Hal cway House Program for Delinquency," Crlme and Delinquency, Vol. 13, No. 4 (October, 1967).

Miller, Lovick C,, "Southfleld--Evaluation of a Short Terr Inpatient Treatment Center for Delinquents." Crime and Delinquency, Vol. I6, Na. 3 (July, 1970).

Post, Q. C., R. A. H1cks and M. F. Monfort, "Day Care Programs for Delinquents: A New Treatment Approach," Crime and Delinguency, Vol. 14, No. 4

Sarcka, Anne, "Halfway Houses," Encyclopedia of Soclal Work, Vol. 1, Nat1onal Association of Soc1al Work, NeW York, 1971. 


\section{APPENDIX A}

\section{ADMISSION CRITERIA FOR YOUTH HOMES IN HOOD RIVER AND WASCO COUNTIES}

I. Circumstances in which a youth w111 be consldered for placement,

A. Youth's General Situation

1. Youth is neglected or abused.

2. Youth's parents are absent or 111.

3. Youth and parents or foster parents are in conflict.

4. Youth is awaling placement by the court or Children's Services Division.

(The 5. Youth has committed a delinquent act and is Dalles) also found to have an important problem as IIsted in Nos. 1,2 and 3 above.

(Hood 5. Youth has comitted a delinquent act but is River) not felt to be dangerous to himself or the community.

B. Youth's Attitude

1. Youth amenable to receiving help.

2. Youth w1Iling to accept placement in the home as an alternative.

3. Youth willing not to run away and keep the house rules.

4. Youth agrees to attend school or ma1ntain employment.

II. Circumstances in which a youth w111 not be considered for placement.

A. Youth's General Situation

1. Youth wro seeks some advantage over his parents and by so dolng would make Improper use of the home.

2. A parent who seeks to use the home as a punishment or threat for the youth.

(The 3. Youth who has comitted some offense but is

Dalies) not experiencing marked conflict on orisis in the horte.

4. Youth is psychobic or is a pyromanlac or sexually deviant. 
B. Youth'a Att1tude

1. Youth does not want help.

2. Youth is not willing to voluntarily accept the home as a planning alternative.

3. Youth w111 make no commitment not to fun away or keep the house mules.

4. Youth refuses to attend school or maintain employment.

5. Youth who w1il make no effort to Improve his behavior.

6. Youth who acts out Violently.

Note: 1. The Dalles accepts youths of both sexes 12 through 17 years of age for a period not generally to exceed 30 days.

2. Hood River accepts youths of both sexes 10 through 18 years of age for a period whtoh may exceed 30 days and become long term care. 
The Next Door, Ind. 1029 May Street

Hood R1ver, Oregon

\section{Dear S1r:}

I would Ilke to request that you accept me for placement in The Next Door Instead of being detalned in some other place.

If you accept me in the home, I agree not to run away, and I also agree to obey all the rules of The Next Door as set forth on the attached sheet as well as the requests and orders of the people operating the home.

$$
\text { Very truly yours, }
$$


STAFFING SHEET

NAME

DATE

$$
\begin{aligned}
& \text { Houseparent Check List } \\
& \text { (olrcle one) }
\end{aligned}
$$

House behavior

School behavior

Communlty behavior

Handles privileges

Relates to houseparents

Relates to peers

organizes self

Follows through

General attitude

Self concept

Bmotional stability

Privilege status:

Notes and Commenta:

Stafing plan:

\begin{tabular}{ccccc} 
Poor & & \multicolumn{3}{c}{ Exceilent } \\
1 & 2 & 3 & 4 & 5 \\
1 & 2 & 3 & 4 & 5 \\
1 & 2 & 3 & 4 & 5 \\
1 & 2 & 3 & 4 & 5 \\
1 & 2 & 3 & 4 & 5 \\
1 & 2 & 3 & 4 & 5 \\
1 & 2 & 3 & 4 & 5 \\
1 & 2 & 3 & 4 & 5 \\
1 & 2 & 3 & 4 & 5 \\
1 & 2 & 3 & 4 & 5 \\
1 & 2 & 3 & 4 & 5
\end{tabular}


APPENDIX B

THE JESNESS INVENTORY

ITEMS COMPOSING SCALE 1 - SOCIAL MALADJUSTMENT

\begin{tabular}{|c|c|c|}
\hline $\begin{array}{l}\text { Item } \\
\text { vo. }\end{array}$ & $\begin{array}{l}\text { Scored } \\
\text { Direction }\end{array}$ & \\
\hline 1. & $T$ & $\begin{array}{l}\text { When you're in trouble, } 1 t^{\prime} \text { s best to } \\
\text { keep quiet about it. }\end{array}$ \\
\hline & $\mathrm{T}$ & I get into a lot of rights. \\
\hline & $\mathrm{T}$ & $\begin{array}{l}\text { I worry too muah about doing the rlght } \\
\text { things. }\end{array}$ \\
\hline 5. & F & $\begin{array}{l}\text { I always Ilke to hang around with the } \\
\text { same bunch of frlends. }\end{array}$ \\
\hline & $\mathrm{T}$ & I am smarter than most boys I know. \\
\hline & F & $\begin{array}{l}\text { It makes me mad that some crooks get } \\
\text { off free. }\end{array}$ \\
\hline & F & Most police w11l try to help you. \\
\hline & F & $\begin{array}{l}\text { A person never knows when he will get } \\
\text { mad, or have trouble. }\end{array}$ \\
\hline 14 & $\mathrm{~T}$ & $\begin{array}{l}\text { If the pollce don't ilke you, they will } \\
\text { try to get you for anything. }\end{array}$ \\
\hline 18 & F & $\begin{array}{l}\text { People always seem to favor a certain } \\
\text { boy or girl anead of the others. }\end{array}$ \\
\hline & $\mathrm{T}$ & $\begin{array}{l}\text { A person like me flghts first and asks } \\
\text { questions later. }\end{array}$ \\
\hline & T & $\begin{array}{l}\text { If I could, I'd just as soon quit } \\
\text { sehool right now. }\end{array}$ \\
\hline & $\mathrm{T}$ & Sometimes it's fun to steal something. \\
\hline & $\mathrm{T}$ & $\begin{array}{l}\text { Women seem more friendly and happy than } \\
\text { men. }\end{array}$ \\
\hline & $\mathrm{T}$ & $\begin{array}{l}\text { Police stick their noses lnto a lot of } \\
\text { things that are none of the1r business. }\end{array}$ \\
\hline & T & I hardly ever get a falr break. \\
\hline & T & A lot of strange things happen ta me. \\
\hline & F & $\begin{array}{l}\text { It would be fun to work in a carnival } \\
\text { or playland. }\end{array}$ \\
\hline & F & $\begin{array}{l}\text { Sometimes people treat grown boys and } \\
\text { girls like they were babies. }\end{array}$ \\
\hline & T & $\begin{array}{l}\text { If someone in your family gets inta } \\
\text { trouble it's better for you to stick } \\
\text { together than to tell the pollee. }\end{array}$ \\
\hline & $\mathrm{T}$ & $\begin{array}{l}\text { It always seems like something bad hap- } \\
\text { pens when I try to be good. }\end{array}$ \\
\hline & T & Most men are bossy and mean. \\
\hline
\end{tabular}


SOCIAL MALADJUSTMENT (CONE' $d$ )

\begin{tabular}{|c|c|c|}
\hline $\begin{array}{l}\text { Item } \\
\text { No. } \\
\end{array}$ & $\begin{array}{c}\text { Scored } \\
\text { Direction }\end{array}$ & \\
\hline 56. & $\mathrm{~T}$ & It seenis Itke wherever I am I'd rather \\
\hline 58. & $\mathrm{~T}$ & I think that someone who is fourteen \\
\hline $\begin{array}{l}64 . \\
67 . \\
70 .\end{array}$ & $\begin{array}{l}T \\
T \\
T\end{array}$ & $\begin{array}{l}\text { Pollce usually treat you dirty. } \\
\text { I of ten feel lonesome and sad. } \\
\text { A lot of tlmes I do things that my } \\
\text { folks tell me I shouldn't do. }\end{array}$ \\
\hline 71. & $T$ & $\begin{array}{l}\text { It's fun to get the police to chase } \\
\text { you. }\end{array}$ \\
\hline 72. & $T$ & $\begin{array}{l}\text { A lot of people say bad thinge about me } \\
\text { behind my back. }\end{array}$ \\
\hline 74. & $T$ & $\begin{array}{l}\text { It seems IIke people keep expecting me } \\
\text { to get Into some k1nd of trouble. }\end{array}$ \\
\hline 76. & $\frac{T}{F}$ & $\begin{array}{l}\text { Other people are happler than I am, } \\
\text { I realiy don't have very many problems } \\
\text { to worry about. }\end{array}$ \\
\hline$\theta$. & $F$ & $\begin{array}{l}\text { Being called a sissy is about the worst } \\
\text { thing I know. }\end{array}$ \\
\hline 83 & $T$ & $\begin{array}{l}\text { If a bunch of you are in trouble, you } \\
\text { should stick together on a story. }\end{array}$ \\
\hline $\begin{array}{l}B 2 \\
85 .\end{array}$ & T & $\begin{array}{l}\text { I have a lot of headaches. } \\
\text { I would rather be alone than with } \\
\text { others. }\end{array}$ \\
\hline 90 & $T$ & $\begin{array}{l}\text { Pollcemen and judges will tell you one } \\
\text { thing and do another. }\end{array}$ \\
\hline 103 & F & $\begin{array}{l}\text { Parents are always nagging and ploking } \\
\text { on yourg people. }\end{array}$ \\
\hline 108 & $\frac{T}{F}$ & $\begin{array}{l}\text { My } 11 \text { fe at home is always happy. } \\
\text { A lot of women seem bossy and mean. } \\
\text { Nobody seems to understand me or how I } \\
\text { feel. }\end{array}$ \\
\hline $\begin{array}{l}113 \\
118 \\
121\end{array}$ & $\begin{array}{l}\mathrm{T} \\
\mathrm{T} \\
\mathrm{T}\end{array}$ & $\begin{array}{l}\text { I am always kind, } \\
\text { I don't mind lying if I'm in trouble, } \\
\text { I woory most of the time. }\end{array}$ \\
\hline & $\mathrm{T}$ & $\begin{array}{l}\text { If youlre not in with the gang, you may } \\
\text { be in for some real trouble. }\end{array}$ \\
\hline 124 & $\begin{array}{l}\mathrm{T} \\
\mathrm{T}\end{array}$ & $\begin{array}{l}\text { My mina is full of bad thoughts, } \\
\text { Sometimes when my folks tell me not to } \\
\text { do something, I go ahead and do it any- } \\
\text { way. }\end{array}$ \\
\hline $\begin{array}{l}128 \\
750\end{array}$ & $\underset{T}{T}$ & $\begin{array}{l}\text { I hardly ever feel excited or thrliled. } \\
\text { When something bad happens, I almost } \\
\text { always blame myself lnstead of the } \\
\text { other person. }\end{array}$ \\
\hline
\end{tabular}


SOCIAL MALADJUSTMENT (Cont' $a)$

\begin{tabular}{|c|c|c|}
\hline $\begin{array}{l}\text { Item } \\
\text { No. }\end{array}$ & $\begin{array}{l}\text { Scored } \\
\text { Direction }\end{array}$ & \\
\hline 130. & T & $\begin{array}{l}\text { The people who run things are usualiy } \\
\text { against me. }\end{array}$ \\
\hline 132. & F & $\begin{array}{l}\text { Most people who act so perfeot are just } \\
\text { putting on a blg front. }\end{array}$ \\
\hline 135. & $T$ & $\begin{array}{l}\text { I think my mother shoula be strieter } \\
\text { than she is about a lot of things. }\end{array}$ \\
\hline $\begin{array}{l}136 . \\
137 .\end{array}$ & $\begin{array}{l}T \\
T\end{array}$ & $\begin{array}{l}\text { I like to read and study. } \\
\text { I reel alone even when there are pther } \\
\text { people around ine. }\end{array}$ \\
\hline $\begin{array}{l}140 . \\
141 .\end{array}$ & $\begin{array}{l}T \\
F\end{array}$ & $\begin{array}{l}\text { I often have trouble getting ny breath. } \\
\text { I worry about how well I'm dolng in } \\
\text { school. }\end{array}$ \\
\hline 146. & $\frac{T}{T}$ & $\begin{array}{l}\text { I am nervous. } \\
\text { Stealing lsn't so bad if lt's from a } \\
\text { rich person. }\end{array}$ \\
\hline $\begin{array}{l}149 . \\
150 .\end{array}$ & $\frac{T}{T}$ & $\begin{array}{l}\text { Things don't seem real to me. } \\
\text { I am afraid of the dark. } \\
\text { Families argue too much. }\end{array}$ \\
\hline 65 & $\mathrm{~T}$ & $\begin{array}{l}\text { I think there is something wrong with } \\
\text { my mind. } \\
\text { When I get into trouble, it's usually } \\
\text { my own fault. }\end{array}$ \\
\hline
\end{tabular}

ITEMS COMPOSING SCALE 2 - VALUE ORIENTATION

5. T I always like to hang around with the same bunch of friends.

9. F Most pollce will try to help you.

I2. T Most people will cheat a little io order to make some tioney.

20. T Most pollce are pretty dumb.

23. T I have very strange and funny thoughts

24. I It's hard to have fun unless you're with your ouddies.

28. T I notice ny heart beats very Iast. when people keep asking me questions.

29. T When I get really mad, I'Il do just about anything.

30. T Women seem more frlendly and happy than

32. T Police stick their noses into a lot of things that are none of their business. 
VALUE ORIENTATION (Cont ${ }^{t} d$ )

\begin{tabular}{|c|c|c|}
\hline $\begin{array}{l}\text { Item } \\
\text { No. }\end{array}$ & $\begin{array}{l}\text { Scored } \\
\text { Direction }\end{array}$ & \\
\hline 40. & $T$ & Wining a fight is about the best fun \\
\hline 47. & $\mathrm{~m}$ & Sometimes I feel dizzy for no peason. \\
\hline 51. & $T$ & $\begin{array}{l}\text { If someone in your family gets into } \\
\text { trauble, it's better for you to stick } \\
\text { together than to tell the police. }\end{array}$ \\
\hline 53. & $T$ & It always seems like something bad hap- \\
\hline 54. & $T$ & Most men are bossy and mean. \\
\hline 56. & T & $\begin{array}{l}\text { It seems } 11 \mathrm{ke} \text { wherever I am I'd rather } \\
\text { be sonewhere else. }\end{array}$ \\
\hline 65. & I & $\begin{array}{l}\text { Most of the time I can't seem to find } \\
\text { anything to do. }\end{array}$ \\
\hline $\begin{array}{l}69 . \\
70 .\end{array}$ & $\underset{T}{T}$ & $\begin{array}{l}\text { Nothing much ever happens. } \\
\text { A lot of times I do things that my } \\
\text { folks teli me I shouldn't do. }\end{array}$ \\
\hline 74. & $T$ & It seems I1ke people keep expecting me \\
\hline 77. & $T$ & $\begin{array}{l}\text { If I could only have a car at home, } \\
\text { things would be all right. }\end{array}$ \\
\hline 81. & T & $\begin{array}{l}\text { If a bunch of you are in trouble, you } \\
\text { should stlck together on a story. }\end{array}$ \\
\hline $\begin{array}{l}\text { 82. } \\
90 .\end{array}$ & $\begin{array}{l}T \\
T\end{array}$ & $\begin{array}{l}\text { I have a lot of headaches. } \\
\text { Pollcemen and judges will tell you one } \\
\text { thing and do another. }\end{array}$ \\
\hline 9 & $T$ & It is hard for me to talk to my parents \\
\hline 98 & $T$ & $\begin{array}{l}\text { It doesn't seem wrong to steal from } \\
\text { crooked store owners. }\end{array}$ \\
\hline $\begin{aligned} 99 . \\
103 .\end{aligned}$ & T & $\begin{array}{l}\text { I would never back down from a flght. } \\
\text { Parents are always nagging and plcking } \\
\text { on young people. }\end{array}$ \\
\hline 107 & $T$ & $\begin{array}{l}\text { At home I am punished too much for } \\
\text { things I don't do. }\end{array}$ \\
\hline 111 & T & $\begin{array}{l}\text { Nobody seems to understand me or how I } \\
\text { feel. }\end{array}$ \\
\hline $\begin{array}{l}118 \\
119 \\
121 \\
133\end{array}$ & $\begin{array}{l}T \\
T \\
T\end{array}$ & $\begin{array}{l}\text { I don't mind lying if I'm In trouble. } \\
\text { A boy who won't right is just no good. } \\
\text { I worry most of the time. } \\
\text { When luck is against you, there isn't } \\
\text { much you can do about is. }\end{array}$ \\
\hline 143. & $T$ & $\begin{array}{l}\text { People hardly ever glve me a falr } \\
\text { chance. }\end{array}$ \\
\hline 144 & T & $\begin{array}{l}\text { I Ilke to daydream more than anyting } \\
\text { else. }\end{array}$ \\
\hline
\end{tabular}


VALUE ORIENTATION (Cont'd)

\begin{tabular}{|c|c|c|}
\hline $\begin{array}{l}\text { Item } \\
\text { No. }\end{array}$ & $\begin{array}{l}\text { Scored } \\
\text { Direction }\end{array}$ & \\
\hline 147. & T) & $\begin{array}{l}\text { Stealing isn't so bad if It' e from a } \\
\text { rich person. }\end{array}$ \\
\hline 152. & $\mathrm{~T}$ & $\begin{array}{l}\text { Sometimes it seems like I'd rather get } \\
\text { into trouble, instead of trylng to stay }\end{array}$ \\
\hline 155. & F & $\begin{array}{l}\text { When I get into trouble, } 1 t \text { 's usually } \\
\text { my own fault. }\end{array}$ \\
\hline
\end{tabular}

ITEMS COMPOSING SCALE 3 - IMMATURITY

8. T My feelings get hurt easily when I am scolded or criticlzed.

11. F When somebody orders me to do something I usually feel like dolng Just the opposite.

12. F Most people will cheat a 11ttie in order to make some money.

13. F A person never knows when he will get

18. F

19.

31. mad, or have trouble.

F People always seem to favor a certaln boy or glrl ahead of the others. I never ile. It $1 \mathrm{~s}$ easy for me to talk to strangers. A lot of fathers don't seem to care if they hurt your feellngs. only a baby cries when he $1 \mathrm{~s}$ hurt. Most adults are really very nice. I have all the friends I need. Nowadays they make it a big orime to get into a Ilttle mischief. Somet1mes people treat grown boys and girls Ilke they were bables. When things Bo wrong, there isn't much you can do about it. Once in a while I get angry. folks tell me I shoulan't do. I like everyone I know. other people are happler than I am. Belng called a sissy is about the worst thing I know. If a bunch of you are in trouble, you should stick together on a story, 
IMMATURITY (Cont'd)

\begin{tabular}{|c|c|c|}
\hline $\begin{array}{l}\text { Item } \\
\text { No. }\end{array}$ & $\begin{array}{c}\text { Scored } \\
\text { D1rect1on }\end{array}$ & \\
\hline 83. & F & Teachers always have favorites who can \\
\hline 84. & $T$ & Every day is full of things that keep \\
\hline 86. & $T$ & $\begin{array}{l}\text { I can't seem to take much kididng or } \\
\text { teasing. }\end{array}$ \\
\hline $\begin{array}{l}88 . \\
92 . \\
95 . \\
96 .\end{array}$ & $\begin{array}{l}T \\
T \\
T \\
T\end{array}$ & $\begin{array}{l}\text { I never get mad at anybody. } \\
\text { I am } 11 \text { ked by everybody who knows me. } \\
\text { I am always nice to everyone. } \\
\text { It takes someone pretty smart to get } \\
\text { ahead of me. }\end{array}$ \\
\hline 101 & $T$ & $\begin{array}{l}\text { I will do a lot of crazy things if } \\
\text { somebody dares me. }\end{array}$ \\
\hline 104 & $T$ & $\begin{array}{l}\text { Some day I would ilke to drive a race } \\
\text { car. }\end{array}$ \\
\hline $\begin{array}{l}108 \\
112\end{array}$ & $\begin{array}{l}T \\
T\end{array}$ & $\begin{array}{l}\text { My Ilfe at home } 1 \mathrm{~s} \text { always happy. } \\
\text { Most people get into trouble because of } \\
\text { bad luck. }\end{array}$ \\
\hline $\begin{array}{l}115 \\
120\end{array}$ & $\begin{array}{l}\text { F } \\
T\end{array}$ & $\begin{array}{l}\text { Sometimes I don't like school. } \\
\text { To get along all right nowadays, à per- } \\
\text { son has to be pretty tough. }\end{array}$ \\
\hline 125 & T & $\begin{array}{l}\text { When you're in trouble, nobody much } \\
\text { cares to help you. }\end{array}$ \\
\hline 126. & F & $\begin{array}{l}\text { Sometimes when my folks teli me not to } \\
\text { do somethinis, I go ahead and do it anyway. }\end{array}$ \\
\hline 127 & T & $\begin{array}{l}\text { It's best not to think about your proo- } \\
\text { lems. }\end{array}$ \\
\hline 131 & $\mathrm{~T}$ & $\begin{array}{l}\text { I have too much trouble making up ny } \\
\text { mind. }\end{array}$ \\
\hline 12 & F & $\begin{array}{l}\text { Most people who act so perfect are just } \\
\text { puting on a big front. }\end{array}$ \\
\hline 13 & T & I get tired easily. \\
\hline & F & $\begin{array}{l}\text { I always hate it when I have to ask } \\
\text { someone for a favor. }\end{array}$ \\
\hline 140 & $\begin{array}{l}T \\
T\end{array}$ & $\begin{array}{l}\text { I often have trouble getting my breath. } \\
\text { The only way to really settle anything } \\
\text { is to flght it out. }\end{array}$ \\
\hline & $\frac{T}{F}$ & $\begin{array}{l}\text { I am afreid of the dark, } \\
\text { Fam11les aregue too much. }\end{array}$ \\
\hline
\end{tabular}


ITEMS COMPOSING SCALE 4 - AUTISM

\begin{tabular}{|c|c|c|}
\hline $\begin{array}{l}\text { Item } \\
\text { No. }\end{array}$ & $\begin{array}{l}\text { Scored } \\
\text { Direction }\end{array}$ & \\
\hline 17 . & $T$ & Somet 1mes I feel 11ke I don't really \\
\hline 18. & B & People always seem to favor a certaln \\
\hline 24. & F & $\begin{array}{l}\text { It's hard to have fun unless you're } \\
\text { with your buddies. }\end{array}$ \\
\hline 47. & $\frac{\mathrm{T}}{\mathrm{F}}$ & $\begin{array}{l}\text { Sometimes I feel dizzy for no reason. } \\
\text { It makes me feel bad to be bawled out }\end{array}$ \\
\hline 60 , & $T$ & $\begin{array}{l}\text { or oriticized. } \\
\text { If somebody does something mean to me, } \\
\text { I try to get back at them. }\end{array}$ \\
\hline 71. & $\mathrm{~T}$ & $\begin{array}{l}\text { It's fun to get the police to chase } \\
\text { you. }\end{array}$ \\
\hline 72 . & $\mathrm{T}$ & $\begin{array}{l}\text { A Iot of people say bad things about me } \\
\text { behind my back. }\end{array}$ \\
\hline $\begin{array}{l}80 . \\
82, \\
94\end{array}$ & $\frac{\mathrm{T}}{\mathrm{T}}$ & $\begin{array}{l}\text { When I'm alone I hear strange things. } \\
\text { I have a lot of headaches. } \\
\text { Too many people like to act blg and } \\
\text { tough. }\end{array}$ \\
\hline 96. & $T$ & $\begin{array}{l}\text { It takes someone pretty smart to get } \\
\text { ahead of me. }\end{array}$ \\
\hline 97 , & $\mathrm{T}$ & $\begin{array}{l}\text { Talking over your troubles with an } \\
\text { older person seems like "kld stuff," }\end{array}$ \\
\hline 04 & $T$ & $\begin{array}{l}\text { Some day I would like to drive a race } \\
\text { car. }\end{array}$ \\
\hline 6 & $T$ & $\begin{array}{l}\text { I feel sick to my stomach every once } \\
\text { In a while. }\end{array}$ \\
\hline 23. & $T$ & $\begin{array}{l}\text { I really think I'm better looking than } \\
\text { most others my age. }\end{array}$ \\
\hline 134 & $\begin{array}{l}T \\
T\end{array}$ & $\begin{array}{l}\text { I get tined easily. } \\
\text { I feel alone even when there are other } \\
\text { people around me. }\end{array}$ \\
\hline $\begin{array}{l}138 . \\
140 . \\
142 . \\
144 .\end{array}$ & $\begin{array}{l}T \\
T \\
T \\
T \\
T\end{array}$ & $\begin{array}{l}\text { I'm good at out-smarting others. } \\
\text { I of ten bave trouble getting my preath, } \\
\text { For my size, I'm realiy pretty tough. } \\
\text { I like to daydream more than anything }\end{array}$ \\
\hline 145. & $T$ & $\begin{array}{l}\text { The only way to really settle anything } \\
\text { is to plaht it out. }\end{array}$ \\
\hline 147. & $\mathrm{~T}$ & $\begin{array}{l}\text { Stealing isn't so bad if it's from a } \\
\text { rlch person. }\end{array}$ \\
\hline & $T$ & $\begin{array}{l}\text { My parents seem to think I might end pip } \\
\text { being a bum. }\end{array}$ \\
\hline
\end{tabular}


AUTISM (Cont'd)

Item scored

No. Direct1on

149. T Things don't seem real to me,

150. I I am afrald of the dark.

153. T I think there is something wrong with my mind.

ITEMS COMPOSING SCALE 5 - ALIENATION

\begin{tabular}{|c|c|c|}
\hline I. & $T$ & rouble, it's best to \\
\hline z. & F & $\begin{array}{l}\text { keep qulet about } 1 \text { t. } \\
\text { It makes me nervoue to sit sti11 vary } \\
\text { long. }\end{array}$ \\
\hline 14. & $\underset{T}{F}$ & $\begin{array}{l}\text { Most pollce will try to help you. } \\
\text { If the pollce don't like you, they will } \\
\text { try to get you for anything. }\end{array}$ \\
\hline 5. & T & $\begin{array}{l}\text { try to get you for anything. } \\
\text { A person is better off if he doesn't }\end{array}$ \\
\hline 32. & $\mathrm{~T}$ & $\begin{array}{l}\text { trust people. } \\
\text { Pollce stick their noses into a lat of } \\
\text { things that are none of the1r business. }\end{array}$ \\
\hline $\begin{array}{l}35 . \\
39 .\end{array}$ & $\frac{T}{E}$ & $\begin{array}{l}\text { I hardly ever get a falr break. } \\
\text { Most adults are really very nice. }\end{array}$ \\
\hline $80^{\circ}$ & T & I have ali the friends I need. \\
\hline 9 & T & $\begin{array}{l}\text { When things go wrong, there } 1 \text { sn't much } \\
\text { you can do about it. }\end{array}$ \\
\hline 54. & $\underset{T}{T}$ & $\begin{array}{l}\text { Most men are bossy and mean. } \\
\text { I don't care if people ilke me or not. }\end{array}$ \\
\hline & & $\begin{array}{l}\text { You can hardly ever belleve what parents } \\
\text { teli you. }\end{array}$ \\
\hline 64 & $\underset{T}{T}$ & Police usually treat you alrty. \\
\hline & $\pi$ & $\begin{array}{l}\text { If a bunch of you are in trouble, you } \\
\text { should stick together on a story. }\end{array}$ \\
\hline 90. & T & Pollcemen and judges w111 tell you one \\
\hline & T & $\begin{array}{l}\text { thing and do another. } \\
\text { Parents are always nageing and pleking }\end{array}$ \\
\hline & & $\begin{array}{l}\text { on young people. } \\
\text { At home I am punished too much for thi }\end{array}$ \\
\hline & & $\begin{array}{l}\text { At home I am punlshed too much for things } \\
\text { I don't do. }\end{array}$ \\
\hline 1 & $\underset{T}{T}$ & $\begin{array}{l}\text { A lot of women seem bossy and mean, } \\
\text { When you' re in trouble, nobody much }\end{array}$ \\
\hline & $T$ & $\begin{array}{l}\text { When you help you. } \\
\text { cares to hel so bot not to think about your }\end{array}$ \\
\hline & & $\begin{array}{l}\text { It's best not to think about your } \\
\text { problems. } \\
\text { I hardy ever feel exclted or thri }\end{array}$ \\
\hline & $T$ & $\begin{array}{l}\text { I hardy ever leel exalted are usuatig } \\
\text { against me. }\end{array}$ \\
\hline
\end{tabular}




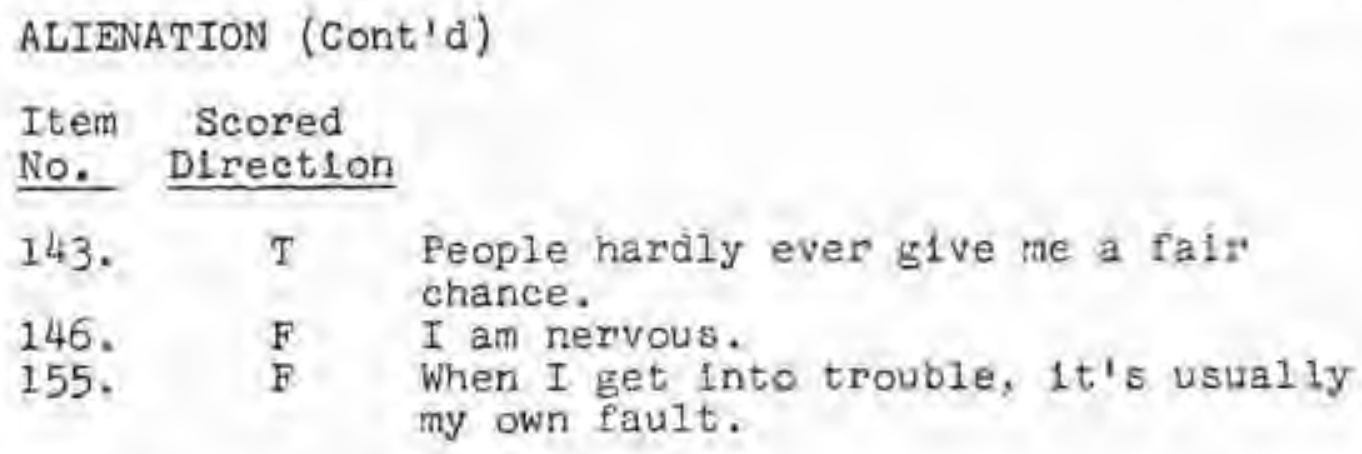

\begin{tabular}{|c|c|c|}
\hline & & to \\
\hline & T & I lways itke to hang around with the \\
\hline 10. & $T$ & $\begin{array}{l}\text { Sometimes I feel } 11 \mathrm{ke} \text { I want to beat up } \\
\text { on somebody. }\end{array}$ \\
\hline 1] & $T$ & $\begin{array}{l}\text { When somebody orders me to do somethine } \\
\text { I usually feel like doing just the }\end{array}$ \\
\hline & T & $\begin{array}{l}\text { opposite. } \\
\text { Most people w1jl cheat a little in } \\
\text { order to make some money. }\end{array}$ \\
\hline 13. & $T$ & $\begin{array}{l}\text { A person never knows when he will get } \\
\text { mad, or have trouble. }\end{array}$ \\
\hline & $T$ & $\begin{array}{l}\text { People always seem to favor a certain } \\
\text { boy or glrl ahead of the others. }\end{array}$ \\
\hline 22 . & $T$ & $\begin{array}{l}\text { A person like me flghts first and asks } \\
\text { questions later. }\end{array}$ \\
\hline & $T$ & $\begin{array}{l}\text { I have very strange and runny thought: } \\
\text { in my mine. }\end{array}$ \\
\hline & $T$ & $\begin{array}{l}\text { It's hard to have fun unless you're } \\
\text { with your buddles. }\end{array}$ \\
\hline & $\underset{T}{T}$ & $\begin{array}{l}\text { Sometimes it's fun to steal somethind. } \\
\text { When I get really mad, I'II do jost } \\
\text { about anything. }\end{array}$ \\
\hline 30 . & $T$ & $\begin{array}{l}\text { Women seem more friendy and happy than } \\
\text { men. }\end{array}$ \\
\hline & $T$ & $\begin{array}{l}\text { A lot of fathers don't seem to care if } \\
\text { they hurt your feellngs. }\end{array}$ \\
\hline & T & $\begin{array}{l}\text { I seen to "olow up" a lot over little } \\
\text { things that realiy don't matter very } \\
\text { much. }\end{array}$ \\
\hline & $\begin{array}{l}\mathrm{F} \\
\mathrm{T} \\
\mathrm{T}\end{array}$ & $\begin{array}{l}\text { Only a baby cries when he is hurt. } \\
\text { A Iot of strange things happen to me. } \\
\text { It always seems like something bad tap- }\end{array}$ \\
\hline & $T$ & $\begin{array}{l}\text { pens when I try to be good. } \\
\text { It seems Ilke wherever I am I'd rather } \\
\text { be somewl:ere else. }\end{array}$ \\
\hline
\end{tabular}


MANIFEST AGGRESSION (Cont' $\theta$ )

\begin{tabular}{|c|c|c|}
\hline $\begin{array}{l}\text { Item } \\
\text { No. }\end{array}$ & $\begin{array}{l}\text { Scored } \\
\text { Direction }\end{array}$ & \\
\hline $\begin{array}{l}62 . \\
65 .\end{array}$ & $\frac{T}{T}$ & $\begin{array}{l}\text { I have a real mean streak in me. } \\
\text { Most of the time I can't seem to find }\end{array}$ \\
\hline & & anything to do. \\
\hline & $\mathbf{T}$ & $\begin{array}{l}\text { Teachers always have lavorites who dan } \\
\text { get away w1th anything. }\end{array}$ \\
\hline 86. & $\mathrm{~T}$ & $\begin{array}{l}\text { I can't seem to take much kldding or } \\
\text { teasing. }\end{array}$ \\
\hline . & $T$ & $\begin{array}{l}\text { I keep wishing something exolting would } \\
\text { happen. }\end{array}$ \\
\hline 13 & $\mathrm{~T}$ & $\begin{array}{l}\text { It seems easier for me to act bad than } \\
\text { to show my good feelings. }\end{array}$ \\
\hline 100. & $T$ & $\begin{array}{l}\text { I have a lot of bad things on my mind } \\
\text { that people don't know about. }\end{array}$ \\
\hline 117. & $T$ & $\begin{array}{l}\text { At times I feel like blowing up over } \\
\text { ilttie things. }\end{array}$ \\
\hline $\begin{array}{l}124 \\
151\end{array}$ & $\begin{array}{l}\mathrm{T} \\
\mathrm{T} \\
\mathrm{T}\end{array}$ & $\begin{array}{l}\text { My mind } 15 \text { full of bad thoughts. } \\
\text { Familfes argue too much. } \\
\text { Sometimes it seems 11ke I'd rather }\end{array}$ \\
\hline & $\mathrm{T}$ & $\begin{array}{l}\text { Into trouble, instead of trying to stay } \\
\text { away from it. } \\
\text { I get angry very quickiy. }\end{array}$ \\
\hline
\end{tabular}

ITEMS COMPOSING SCALE 7 - WITHDRAWAL

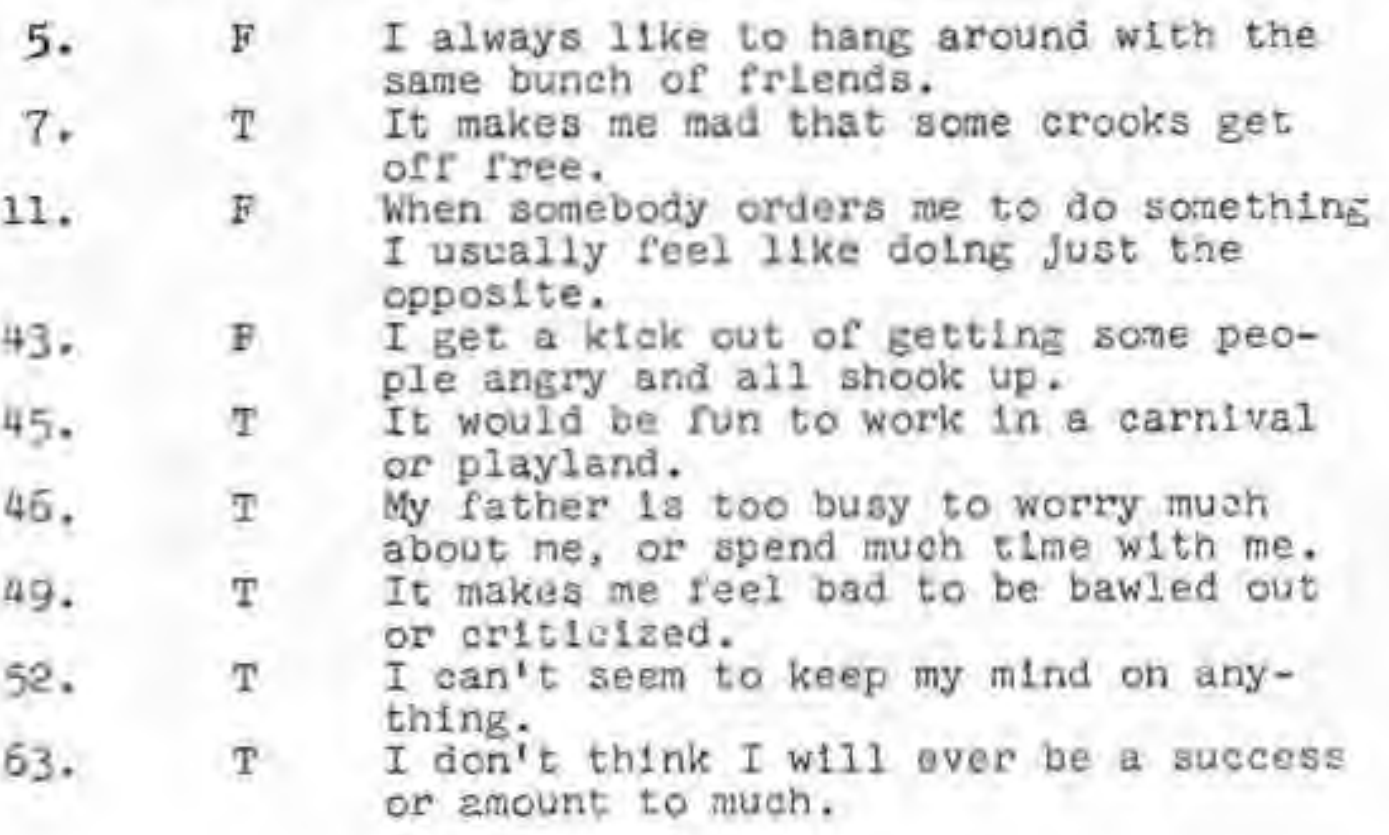


WITHDRAWAL (Cont'd)

\begin{tabular}{|c|c|c|}
\hline $\begin{array}{l}\text { Item } \\
\text { No. }\end{array}$ & $\begin{array}{l}\text { Scored } \\
\text { D1rection }\end{array}$ & \\
\hline $\begin{array}{l}67 . \\
69 . \\
70:\end{array}$ & $\begin{array}{l}T \\
T \\
T\end{array}$ & $\begin{array}{l}\text { I often feel lonesome and sad. } \\
\text { Nothing much ever happens. } \\
\text { A lot of times I do things that my } \\
\text { folks tell me I shouldn't do. }\end{array}$ \\
\hline $\begin{array}{l}76 . \\
77 .\end{array}$ & $\underset{T}{T}$ & $\begin{array}{l}\text { Other people are happler than I am. } \\
\text { If I could only have a car at home, }\end{array}$ \\
\hline 5 & T & $\begin{array}{l}\text { things would be all right. } \\
\text { I would rather be alone than with } \\
\text { others. }\end{array}$ \\
\hline 91. & $\mathrm{~T}$ & $\begin{array}{l}\text { It is hard for me to talk to my parents } \\
\text { about my troubles. }\end{array}$ \\
\hline 94. & $\mathrm{~T}$ & $\begin{array}{l}\text { Too many people like to act } b 1 \mathrm{~g} \text { and } \\
\text { tough. }\end{array}$ \\
\hline 99. & $\begin{array}{l}\mathrm{F} \\
\mathrm{T} \\
\mathrm{T}\end{array}$ & $\begin{array}{l}\text { I would never back down from a fight. } \\
\text { I sit and daydream more than I should. } \\
\text { Nobody seems to understand me or how I } \\
\text { feel. }\end{array}$ \\
\hline $\begin{array}{l}118 . \\
119 \\
121 \\
131\end{array}$ & $\begin{array}{l}\text { F } \\
F \\
T \\
T\end{array}$ & $\begin{array}{l}\text { I don't mind lying if I'm in trouble. } \\
\text { A boy who won't fight is just no good. } \\
\text { I worry most of the time. } \\
\text { I have too much trouble making up my } \\
\text { mind. }\end{array}$ \\
\hline
\end{tabular}

ITEMS COMPOSING SCALE 8 - SOCTAL ANXIETY

\begin{tabular}{|c|c|c|}
\hline - & F & When you're in trouble, 1t's best to \\
\hline 2. & T & It makes me nervous to sit still very \\
\hline 4. & $T$ & $\begin{array}{l}\text { 1ong. } \\
\text { things too much about dolng the right } \\
\text { thlngs. }\end{array}$ \\
\hline 8. & T & $\begin{array}{l}\text { My feelings get hurt easily when I am } \\
\text { scolded or criticlzed. }\end{array}$ \\
\hline 5. & F & $\begin{array}{l}\text { A person is better off } 1 f^{\prime} \text { he doesn'te } \\
\text { trust people. }\end{array}$ \\
\hline & T & $\begin{array}{l}\text { I worry about what other people thitak } \\
\text { of me. }\end{array}$ \\
\hline & T & $\begin{array}{l}\text { I get nervous when I ask someone ta do } \\
\text { me a favor. }\end{array}$ \\
\hline & T & $\begin{array}{l}\text { I notice my heart beats very fast when } \\
\text { people keep asking me questions. }\end{array}$ \\
\hline & E & It is eacy for me to talk to strangers. \\
\hline & $\mathrm{T}$ & a lot of: \\
\hline
\end{tabular}




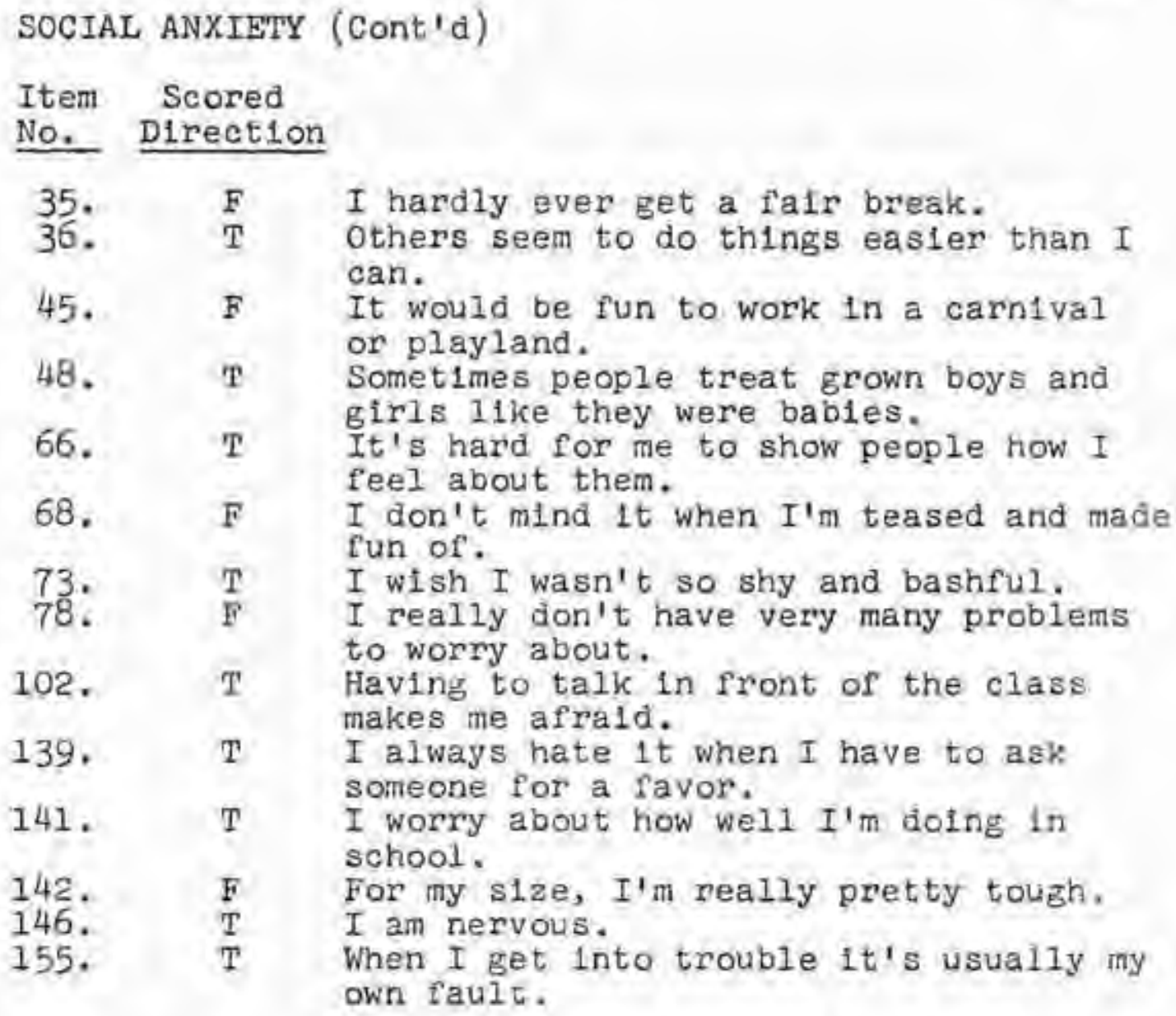

19. T I never lie.

46. F Sometimes people treat grown boys and

glrls like they were bables.

57. $F$ Once in a while I get angry.

68. I I don't mind it when $I^{\prime} m$ teased and made fun of.

75. $\mathrm{T}$ I like everyone I know.

78. T I veally don't have very many problems

88. T I never get mad at anybody.

92. T I am liked by everybody who knows me.

95. I I am always nice to everyone.

My $11 f^{\prime} e$ at home is always happy.

113.

I am always kind.

Sometimes I don't. Ilke school.

125. $\quad \frac{5}{5}$

Sometimes wnen my folks tell me not to do something, I jo ahead and do It anyway. 
RERRESSION (Cont'd)

Itern $\begin{gathered}\text { Scored } \\ \text { No. Direction }\end{gathered}$
129.
$\begin{aligned} & \text { When somethlng bad happens, I almost } \\ & \text { always blame nyself Instead of the } \\ & \text { other person. }\end{aligned}$
$\begin{array}{ll}\text { 136. } & \text { T like to read and study. }\end{array}$

ITEMS COMPOSING SCALE 10 - DENIAL

B. F My feelings get hurt easily when I am 16. scolded or criticized.

16. F Sometimes I wish I could quit school.

17. F Sometimes I feel like I don't really have a home.

33. If A lot of fathers don't seem to eare if they hurt your feelings.

39. T Most adults are really very nice.

46. F My father 1.8 too busy to worry much

53. $\quad$ E

about me, of spend much time with me.

59. F

65. F

It always seems like something bad happens when I try to be good.
66. F It's hard for ine to show people how I
feel about them.

67. I I often feel lonesome and sad.

69. F Nothing much ever happens.

84, T

Every day is full of things that keep me interested.

87. F I don't seem to care enough about what happens to me.

91. $B$ It 1s hard for me to talk to my parients about my troubles.

103. F Parents are always nagging and plcking

107. F At houne I am punished too much for

110. F A lot of women seem bossy and mean.

114. I Talkinis with my parents is just as easy

135. T I think my mother should be stricter than she $1 \mathrm{~g}$ about a lot of things. 


\section{ATTITUDE QUESTIONNAIRE}

clrole the answer that best flts how you feel.

1. Real frlends are hard to find where I 11ve.

Very true True Undecided Ontrue Very untrue

2. Some people in my town "set by with murder" while others take the rap for doing any little thing wrong.

Very true True Undecided Untrue Very untrue

3. People are not concerned about what $k 1 d s$ do a $10 n 5$ as they keep out of trouble.

Very true True Undeclded Untrue Very untrue

Mark an " $\mathrm{X}$ " on the sectlon of the vert1cal 11ne that best describes how you reel. Mark the " $\mathrm{X}$ " between the horlzontal lines, not on them.

4. How do you feel about the community'g (schools, court, pollce, nelishbors, etc.) concern and interest for you?

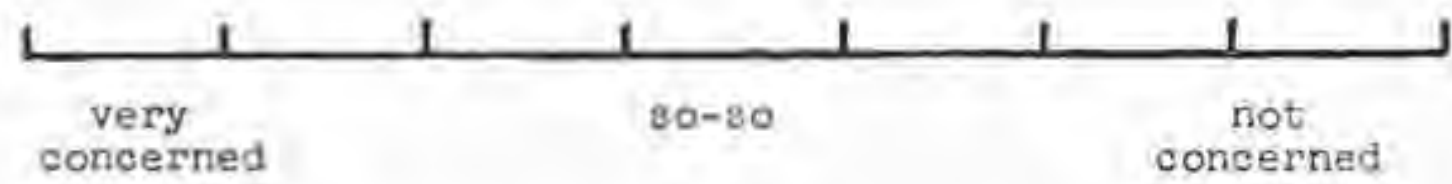

5. Have you learned anything while being here (abott yourself, others, etc.)?

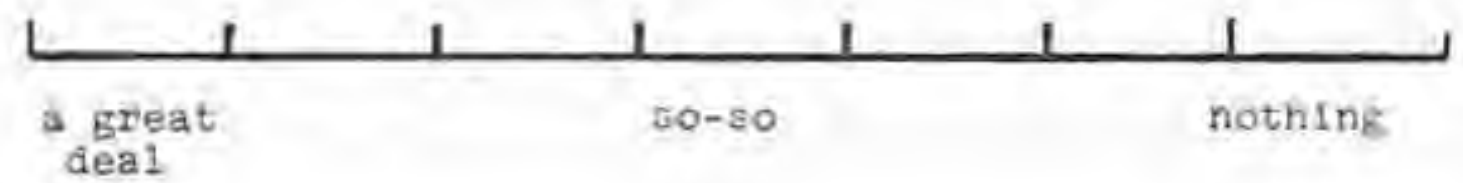


ATTITUDE QUESTIONNAIRE (Cont'd)

6. Are you happy w1th the way you are as a person?

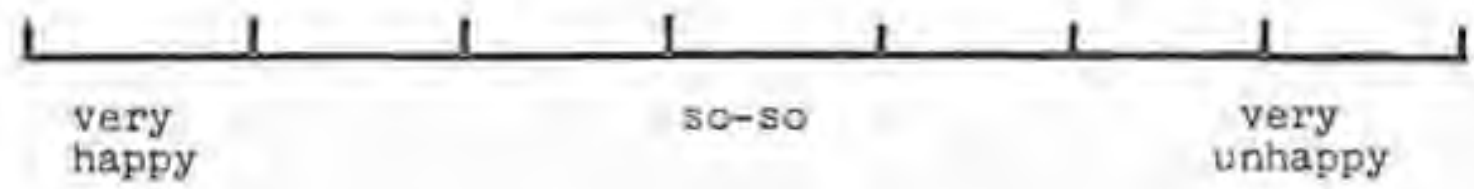

7. Are the houseparents reasonable with thelf expectations and rules for you?

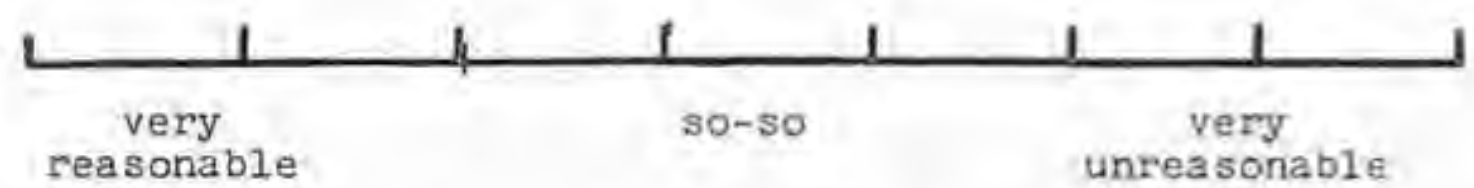

8. How well do you feel you get along with most of the klds here?

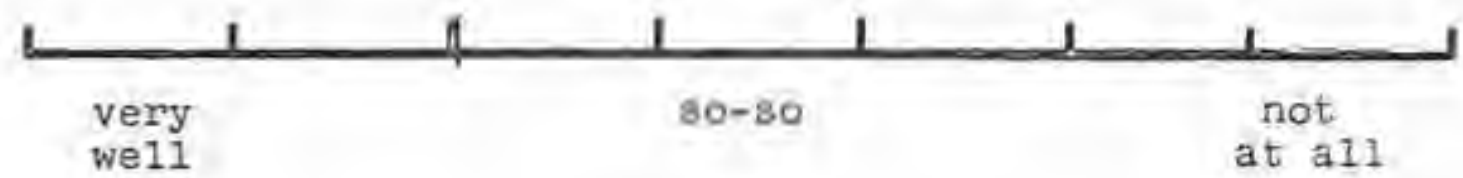




\section{SEMANTIC DIFFERENTIAL SCALE}

Here is a 11 st of twelve words and thelp opposites. The Ilnes in between the words stand for the different degrees of difference between them. Rate the "Next Door, Inc." on all twelve scales by marking an " $X$ " on the IIne between each set of words to show where you feel the Next Door would be. Mark whatever comes to your head f1rst; do not spend much time thinking of your answer.

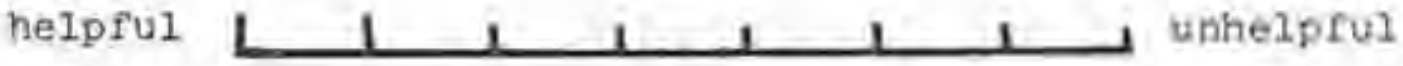

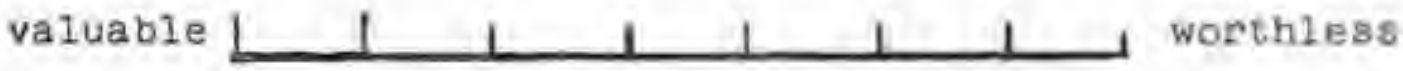
nice

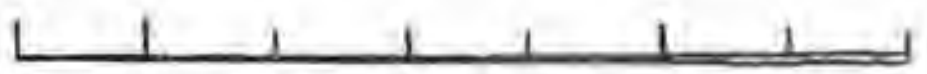
a) IUI

clean

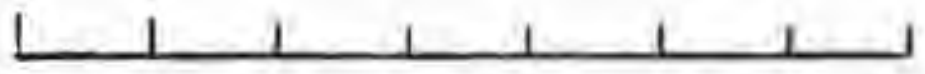

disty

notsy

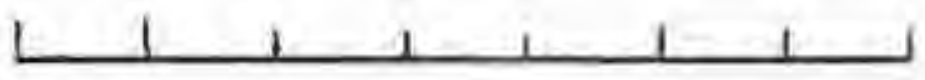

quilet

good

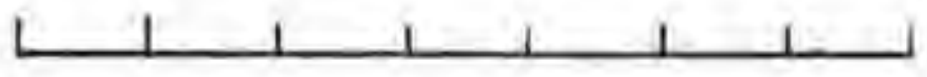

bad

Iarge

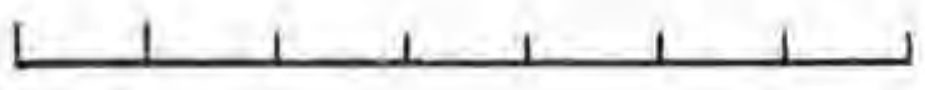

vina 11 strong

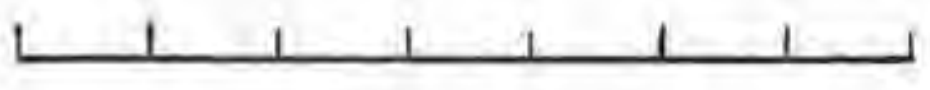

weak

deep
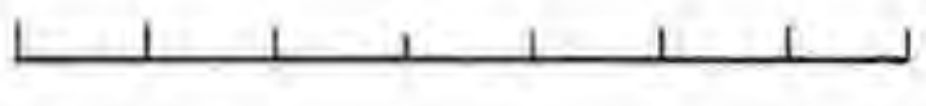

shallow

Past.

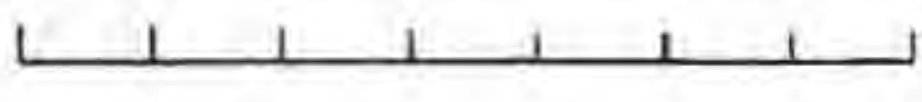

slow

active



pasalve

hot 
SEMANTIC DIFFERENTIAL SCALE (Cont'd)

Following the same instructions as for the last question, rate "Authority" on this same soale.

helpful

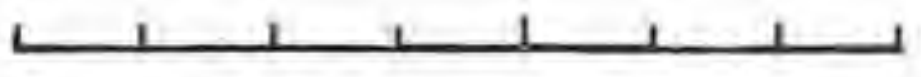

unhe1pful

valuable
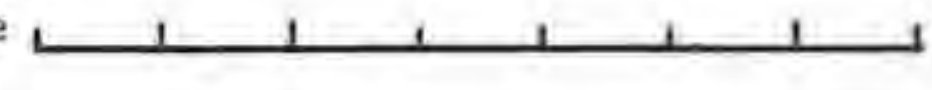

worthless

nice

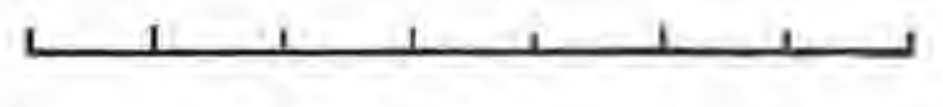

awfut

clean

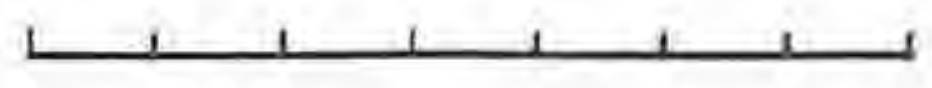

dirty

no1sy

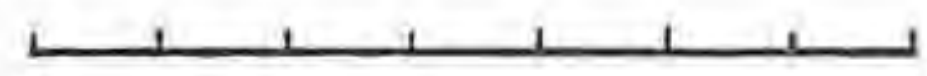

quilet

good

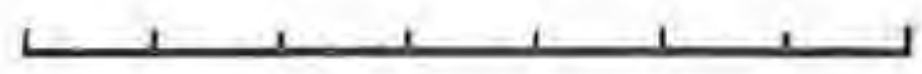

bad

large

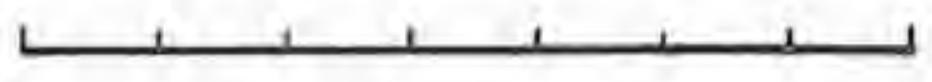

smaIl

strong

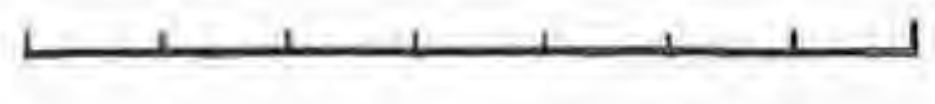

wearc

deep

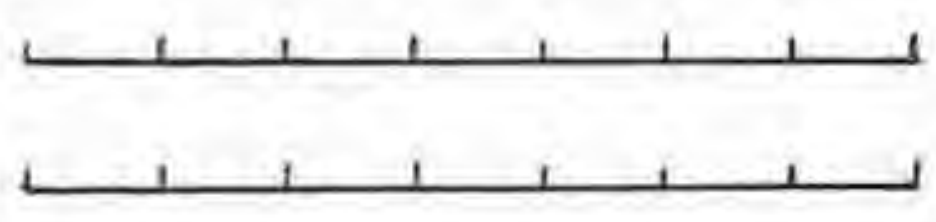

shallow

fast
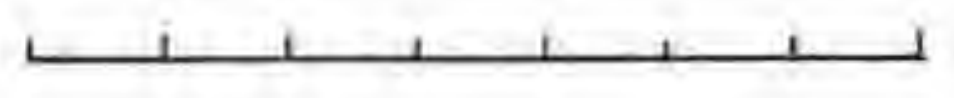

passtve

not

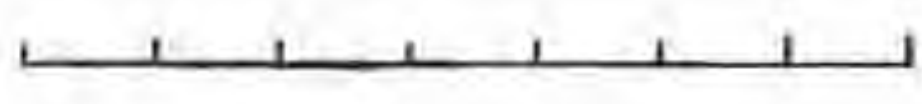

cold 
SEMANTIC DIFFERENTIAL SCALE (Cont'd)

Following the same instructions as for the last question, rate "Me" (yourself') on this same scale.

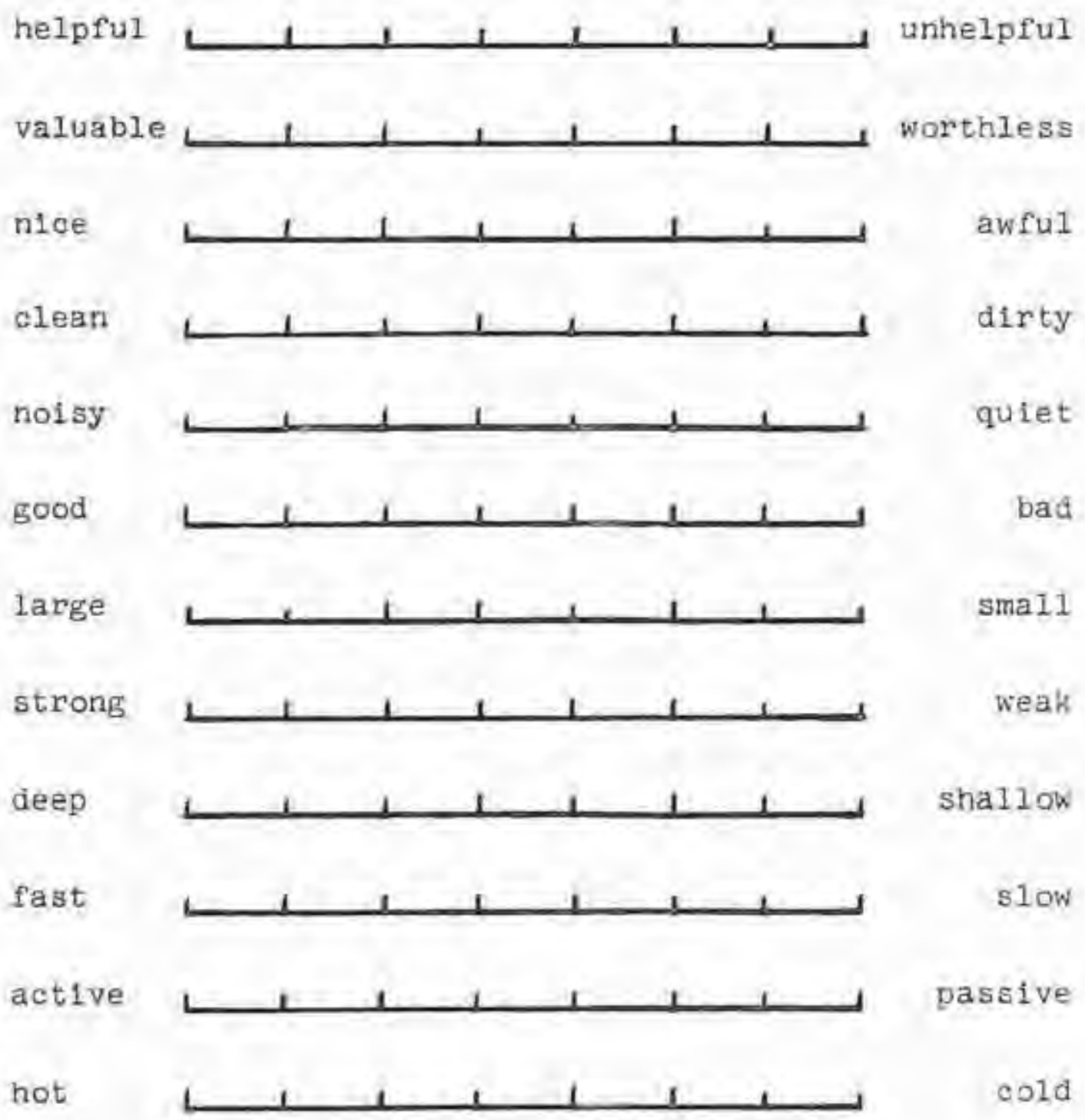

